\title{
OPERAÇÕES ESTRUTURADAS: CONCEITO, OPORTUNIDADES E IMPACTOS NAS FINANÇAS PÚBLICAS
}

\subsection{PROPOSTA DE CONCEITO DE OPERAÇÕES ESTRUTURADAS PARA O DIREITO FINANCEIRO}

A compreensão do direito depende da compreensão e da interpretação dos conceitos que são nele apresentados. Como fenômeno social e linguístico, os conceitos jurídicos apresentam a chamada "textura aberta", podendo haver casos em que a aplicação e apreensão do sentido das normas é perfeitamente simples e casos em que essa aplicação se torna um desafio ${ }^{525}$.

Geraldo Ataliba, escrevendo a partir de uma fundamentação normativista, advogava serem poucos os pontos de contato entre o Direito Financeiro, tido como "mero capítulo do direito administrativo", e a Ciência das Finanças. Consideraçōes de ordem política, econômica e sociológica seriam problema da Ciência das Finanças, ao passo que ao Direito caberia observar exclusivamente as normas jurídicas e os conceitos nucleares do direito, considerados "exclusivamente formais" e estruturados "com instrumental e categorias do direito e informados somente por princípios jurídicos"

$\mathrm{Na}$ doutrina administrativista verifica-se a atenção para o fenômeno da convergência entre os contratos administrativos e os contratos privados da administraçãa ${ }^{527}$. Essa con-

525 WACKS, Raymond. Philosophy of law: a very short introduction, p. 50: "Hart claims that we cannot properly understand law unless we understand the conceptual context in which it emerges and develops. He argues, for instance, that language has an 'open texture': words (and hence rules) have a number of clear meanings, but there are always several 'penumbral' cases where it is uncertain whether the word applies or not."

526 ATALIBA NOGUEIRA, José Geraldo de. Empréstimos públicos e seu regime jurídico, pp. 73-4, nota de rodapé.

527 OLIVEIRA, Rafael Carvalho Rezende. Licitaçôes e contratos administrativos, p. 219: "Registre-se, todavia, que a tendência é a relativização da distinção entre os contratos administrativos e os contratos pri- 


\section{•- Teoria jurídica do crédito público e operações estruturadas}

vergência se dá tanto pela compreensão publicista de que o interesse público não deve servir de justificativa para o desrespeito aos interesses privados ${ }^{528}$, devendo com eles se conciliar, quanto pela compreensão privatista da função social do contrato privado ${ }^{529}$. Não haveria, portanto, clareza na linha fronteiriça entre o chamado regime de direito público e o chamado regime de direito privado $^{530}$.

Esses fenômenos são centrais para o nosso trabalho, na medida em que as operações estruturadas são formadas a partir de um complexo de contratos assinados pela Administração com entes públicos e privados, visando ao interesse público, mas em estreita coope-

vados da Administração, especialmente a partir da releitura das cláusulas exorbitantes e uniformização do regime jurídico, inclusive no Direito Comunitário Europeu."

528 Agrega-se a isso a crítica a respeito da ideia de interesse público, conforme SCHIRATO, Vitor Rhein. As empresas estatais no direito administrativo econômico atual, p. 151: "Em uma sociedade pluriclasse na qual cada vez mais se concede poder de participação aos mais distintos grupos sociais, não há como falar na existência de um interesse público homogêneo, claro e aferível em qualquer caso. Há, nas decisões públicas, um embate de diversos interesses coletivos legítimos que merecem tutela pelo Ordenamento Jurídico. E, nesse sentido, o exercício do poder de controle nas empresas estatais é absolutamente emblemático, visto que nada mais configura do que um conflito entre o interesse do Estado e os interesses de diversos agentes, incluindo os acionistas minoritários." E na página 177: "Destarte, o que temos hoje na esteira do que já desenvolvemos em diversos trechos desta obra - é a existência de uma pluralidade de interesses coletivos dotados de legitimidade, que, após processo de arbitramento e ponderação, resultam na eleição de um interesse coletivo que prevalece no caso concreto (interesse público propriamente dito ou interesse público primário, conforme acepção atual do termo) sobre outros interesses coletivos e privados, que devem ser respeitados pela Administração Público, e de outros interesses privados da própria Administração Pública, na qualidade de titular de direitos e obrigaçōes.

O que é tutelado pelo Ordenamento jurídico é o interesse público - fruto da mediação e da ponderação de diversos interesses coletivos dotados de legitimidade - e os interesses privados juridicamente protegidos. Os interesses privados da Administração Pública não recebem qualquer proteção do Ordenamento Jurídico. Contudo, entendemos equivocada a simples negativa de sua existência, como fazem alguns autores. Não é porque algo não encontra proteção jurídica que simplesmente não existe. Muito ao contrário, deve ser constatada sua existência para que sejam aplicáveis os remédios jurídicos cabíveis."

529 OLIVEIRA, Rafael Carvalho Rezende. Op. cit., pp. 234-5: "É importante notar, contudo, que a afirmação da supremacia da Administração nos contratos administrativos, em razão da presença natural/ automática das cláusulas exorbitantes, começa a ser relativizada por parcela da doutrina.

Isto porque o tradicional princípio da supremacia do interesse público sobre o privado tem sido questionado a partir dos argumentos assim sintetizados: a) o interesse público e os direitos fundamentais não são necessariamente colidentes e não são hierarquizados pela Constituição Federal; b) em vez de supremacia abstrata, o administrador deve justificar, concretamente, a prevalência do interesse a ser satisfeito em cada atuação.” No mesmo sentido Fernando Dias de Almeida, com base em Hans Kelsen, ALMEIDA, Fernando Dias Menezes de. Contrato administrativo, p. 116: "Conceber, enfim, a distinção entre Direito público e privado como algo absoluto - expressando, no primeiro caso, a relação de sujeitos de valor diverso, que se confrontam numa relação antes de poder, do que juridicamente em sentido estrito - não tem caráter científico, senão de caráter ideológico, que pode levar, por exemplo, à tentativa de redução da vinculação da Administração às leis, ou, se outro lado, à sugestão de que não há dominação política no setor do Direito privado.”

530 SCHIRATO, Vitor Rhein. As empresas estatais..., p. 84: "Ademais, a dicotomia público/privado encontra-se em profunda crise. Não é mais possível divisar com nitidez qual é o espaço público e qual é o espaço privado, dado que o papel dos cidadãos na Administração Pública cresce a cada dia e a ação administrativa se desverticaliza, aproximando-se das relações privadas." 
ração com o mercado privado financeiro e de capitais e, consequentemente, com o interesse privado ${ }^{531}$.

É preciso atentar para o fato de que a chamada "fuga para o direito privado" ocorre em um contexto no qual se reconhece a existência de amarras à ação experimental do agente público como um óbice ao atingimento de resultados mais efetivos e econômicos por parte da Administração Pública ${ }^{532}$. Em que pesem os argumentos e discursos em favor da adoção de um paradigma gerencial na Administração Pública, a forma de controle da Administração praticada reforça inadvertidamente a necessidade de estrito cumprimento de procedimentos ${ }^{53}$, o que termina por levar a consequências desastrosas no que se refere aos níveis de eficiência observados pelo setor público ${ }^{534}$.

É preciso que se reconheça que o experimentalismo é parte do dia a dia das organizações, inclusive das organizaçôes públicas, e que esse experimentalismo, por vezes, conduzirá a falhas que precisarão ser corrigidas. Isso não se confunde com aceitar o improviso

531 SCHIRATO, Vitor Rhein. Os sistemas de garantia nas parcerias público-privadas: "Perde o sentido alegar que este ou aquele instituto jurídico é típico do Direito privado ou do Direito público. Há inegável tendência de adoção de instrumentos privados pela Administração Pública e somente com a efetivação desta tendência é que se poderá ter projetos sérios e sólidos no campo da PPP. Conquanto sejam atendidos os direitos e as garantias fundamentais dos cidadãos e sejam realizados legalmente tendo o termo legalmente função ampla, incluindo todo o Direito, que é uno e indivisível os fins do Estado, de acordo com os cânones da Constituição Federal, não há o que se questionar, há apenas de se aplicar a lei aplicável."

532 ESTORNINHO, Maria João. A Fuga para o Direito Privado: Contributo para o Estudo da Atividade de Direito Privado da Administração Pública, pp. 39-40: “(...) esse carácter mais activo e mais interventor da Administração Pública é indissociável só seu recurso a novos métodos de actuação. Na verdade, esta actuação intervencionista do Estado nem pré exequível através da organização burocrática tradicional da Administração Pública, pelo que esta precisa de recorrer a novos modelos de organização e de actuação mais flexíveis e dinâmicos. E, se esta utilização do Direito Comum era inicialmente muito limitada, reduzindo-se praticamente à aquisição contratual dos bens indispensáveis ao funcionamento da Administração e ao desenvolvimento da sua actividade, aos poucos cresceu e generalizou-se."

533 PIRES, Roberto Rocha C. Beyond the fear of discretion: flexibility, performance, and accountability in the management of regulatory bureaucracies, p. 3: "Research in different fields - such as socio-legal studies (Bittner 1967, 1990; Wilson 1968; Van Maanen 1973, 1978; Brown 1981; Silbey \& Bittner 1982) and policy studies (Leonard 1977; Lipsky 1980; Wilson 1989; Maynard-Moody \& Musheno 2003) - has empirically demonstrated that bureaucratic discretion is pervasive and possibly indispensable in legal and administrative systems. Despite what appears to be the inevitability of discretion, debates have more often been characterized by the fear of bureaucratic tyranny and the risks of unchecked decisionmaking than by the potential benefits of responsible exercise of discretion." Já tivemos a oportunidade de tratar desse tema da perspectiva das normais penais aplicáveis à administração pública. Ver ARELLANO, Luis Felipe Vidal. Administração pública gerencial e Direito Penal burocrático: implicações na dogmática penal da aplicação do gerencialismo na administração pública brasileira.

534 PIRES, Roberto Rocha C. Idem, ibidem: "Retrospective evaluations have demonstrated that legal procedures and oversight do reduce levels of discretion. However, they also showed that the remedy has been as bad as (if not worse than) the disease. For example, Bryner (1987) and Handler (1986) documented how excessive and misdirected actions to reduce discretion have damaged the capability of public sector organizations to accomplish delegated tasks, by making administrative processes more confusing and in general reducing the ability of agencies to function effectively. As a result, additional attention to bureaucratic procedures has undermined parallel attention to aiding organizations making the complex decisions necessary for the implementation of policies and regulation." 


\section{•• Teoria jurídica do crédito público e operações estruturadas}

no setor público, mas implica aceitar como natural uma maior carga de incerteza quanto às consequências da ação estatal, em virtude da inevitável incompletude da informação detida pelo agente público e, consequentemente, das justificativas e motivações apresentadas pelo agente público como fundamento para a sua ação administrativa. $O$ grande desafio, portanto, não se encontra apenas no alinhamento de incentivos no setor público e na cobrança de resultados, mas, em última instância, na formulação de procedimentos e instituições que permitam ao Poder Público, junto à sociedade, construir as melhores soluçôes possíveis para problemas complexos, observada a racionalidade limitada existente tanto no setor público quanto no setor privado ${ }^{535}$.

O regime contratual de direito público não é outra coisa senão o conjunto de regras voltado à concessão de faculdades especiais à Administração Pública, tendo em vista o interesse público que orienta as suas contratações, assim como a concessão de garantias específicas ao contratado, sobretudo o resguardo do equilíbrio econômico-financeiro do acordo original ${ }^{136}$, como compensação às prerrogativas detidas pela Administração.

Contudo, conforme já argumentamos, não é certo afirmar que as cláusulas exorbitantes, típicas do regime contratual de direito público, sejam sempre um benefício para a Administração. É seguro dizer que a presença dessas cláusulas nos contratos com a Administração é levada em consideração na precificação dos bens e serviços demandados pela Administração, sendo certamente um dos responsáveis pela diferença de preços de mesmos itens quando adquiridos por particulares ou entes públicos. Por esta razão também, deve-se relativizar a capacidade de se atender ao interesse público por meio das cláusulas exorbitantes ${ }^{537}$.

535 Sobre o experimentalismo na Administração Pública, ver PIRES, Roberto Rocha C. Op. cit., p. 4: “The second model, the Experimentalist Governance (EG) approach, emerges as a criticism by EG scholars (such as C. Sabel, J. Zeitlin, M. Dorf, and W. Simon) of the untenability of the economic, rational framework at the heart of NPM proposals, most specifically the principal-agent relationship. Drawing from institutional economics, NPM models in general separate conception from execution and assume the existence of principals (be they civil society actors, political parties, elected officials, etc.) who already know what needs to be done to solve collective problems. (...) In contrast, EG scholars argue that there are no such principals in the polity with the robust and panoramic knowledge or unchallenged consensus assumed for this directive role. Therefore, the main problem for reform is not to determine performance targets and the right incentive system, but to determine ways actors can interact, discover, and learn together what needs to be done, and how to do it (Sabel 2004, 2005).

Thus, in this second managerial model of regulation, the solution to achieving regulatory efficacy requires experimentalist organizations 'that assume the provisionality of their goals and institutionalize social learning by routinely questioning the suitability of their current ends and means, and by periodically revising their structures in light of the answers' (Sabel 2004, p. 4). Experimentalist organizations display the attitude of constantly detecting and correcting errors at the lowest levels, and then adjusting the higher level structures to generalize successes and encourage more refined error detection.”

536 SCHIRATO, Vitor Rhein. Op. cit., p. 112: “... De forma muito genérica, para não nos desviar do foco do presente estudo, pode-se entender que o regime jurídico de Direito público dos contratos nada mais é do que a conferência, por um lado, de poderes extraordinários à Administração Pública, que quebram a horizontalidade da relação contratual (as chamadas cláusulas exorbitantes), e, por outro lado, de garantias especiais ao contratado (principalmente o direito à manutenção do equilíbrio econômico-financeiro da avença), em contrapartida aos poderes da Administração Pública.”

537 OLIVEIRA, Rafael Carvalho Rezende. Op. cit., p. 235: "As prerrogativas unilaterais em favor do Estado desequilibram a relação contratual, gerando insegurança e risco ao particular que, naturalmente, 
Quanto tratamos de operações estruturadas, no sentido da expressão utilizado neste trabalho, estamos no contexto de operaçôes financeiras e contratuais que implicam no comprometimento do orçamento estatal por prazos normalmente superiores aos de vigência normal dos créditos orçamentários. Nestas operaçôes, que visam a alocar de forma específica recursos públicos e privados, além de deslocar riscos no tempo e entre agentes, a engenharia financeira e contratual que se empreende visa a possibilitar o financiamento de projetos de alto vulto financeiro, grande risco de execução (seja de construção ou de operação), e retornos sociais elevados.

Desponta, ademais, que a distinção entre o mercado financeiro e o mercado de capitais, baseada na existência de intermediários financeiros no primeiro, na figura dos bancos, em contraposição ao recurso direto aos poupadores proporcionado pelo mercado de capitais, perde seus contornos claros a cada dia, em razão da própria evolução dos instrumentos financeiros e também da regulação dos respectivos mercados, que permitem cada vez mais a existência de pontos cegos e de pontos de sobreposição ${ }^{538}$. Assim, não apenas a fronteira entre o direito público e o privado se tornam menos nítidas, mas também as próprias disciplinas teóricas no campo privado, aplicáveis às operaçôes estruturadas, passam a se interpor e se confundir.

A característica de comprometimento fiscal no longo prazo das operações estruturadas, aliada à construção ad hoc de muitas das combinaçôes possíveis de instrumentos jurídicos comuns do meio privado, mas ainda pouco empregados pelos governos, leva, por vezes, a uma classificação apressada de tais operaçôes como operaçôes de crédito, sujeitando-as às restrições constitucionais e legais que vimos descrevendo até o presente momento neste trabalho. Ainda que se possam identificar alguns pontos comuns entre as operações de crédito e algumas operações estruturadas, em geral, a forma de alocação de riscos e de deslocamento espacial e temporal dos recursos em cada um dos casos é absolutamente diversa, sendo suficiente para afastar as regras restritivas contidas, principalmente, na LRF.

Isso não implica dizer, por outro lado, que as operaçôes estruturadas devam ser mantidas fora do campo de atenção do direito financeiro e das normas relativas à responsabi-

embutirá o risco incerto em sua proposta apresentada durante o procedimento licitatório, elevando o preço a ser cobrado do poder público.”

538 CATAPANI, Márcio Ferro. Títulos públicos: natureza jurídica e mercado-LFTs, LTNs, NTNs, TDAs e Tesouro Direto, pp. 240-1: "Uma das diferenças essenciais entre o mercado financeiro stricto sensu e o de capitais é que, no primeiro, dá-se a denominada intermediação financeira, com instituições que genericamente podem ser denominadas de bancos captando recursos de alguns agentes e repassando-os a outros. Destarte, as instituiçôes em tela assumem diretamente o risco do inadimplemento. Já no mercado de capitais, o fenômeno que ocorre é o da desintermediação financeira, havendo aqueles que necessitam desses recursos para exercer suas atividades. E, nesse caso, o risco passa a ser sofrido diretamente pelo investidor.

A distinção entre tais mercados, em geral, não tem maior utilidade prática. Se, no passado, podia-se afirmar com alguma segurança que o ente regulador do mercado financeiro stricto sensu e do mercado monetário era o Bacen, sendo a regulação do mercado de valores mobiliários competência da CVM, tal tese não mais se sustenta nos presentes dias. A evolução no tratamento dos temas financeiros evoluiu e continua evoluindo de forma a dificultar uma visão conceitual estanque dos instrumentos negociados em cada um desses mercados." 
lidade fiscal. Como será demonstrado, é possível que o quadro seja exatamente o contrário, a justificar atenção por parte da doutrina jurídica e também da literatura econômica, para os riscos potenciais, em alguns casos, da adoção de estratégias de operações estruturadas em lugar de operaçôes convencionais de financiamento. Isso é especialmente relevante no caso de operações envolvendo parcerias público-privadas e no caso de operaçóes realizadas por meio da constituição de empresas estatais.

Passamos, outrossim, à análise de algumas das expressões mais comuns de operações estruturadas, buscando em cada uma delas identificar as características que despontam como itens a justificar a atenção da dogmática jurídica para a relação entre operações estruturadas e endividamento público, em especial em face dos dilemas até aqui apresentados relativos ao impacto do endividamento sobre a igualdade entre gerações e igualdade entre regióes no país.

\subsection{OPERAÇ̃̃ES ESTRUTURADAS NO SETOR PÚBLICO E IMPACTOS FISCAIS}

\subsubsection{Operações envolvendo empresas estatais}

A história das empresas estatais confunde-se com a história das sociedades anônimas, assim como com a história do financiamento público. Isto, pois na origem das sociedades anônimas estava a necessidade de o Estado financiar empreendimentos arriscados nas novas terras descobertas no continente Americano e nas Índias Orientais ${ }^{539}$. Assim, essas sociedades foram no seu início o mecanismo de captação de recursos para empreendimentos específicos de interesse estatal ${ }^{540}$.

539 FERGUSON, Niall. The ascent of money: a financial history of the world, pp. 128-9: "The story of the company had begun a century before Law's arrival and had its origins in the efforts of Dutch merchants to wrest control of the lucrative Asian spice trade from Portugal and Spain. Europeans craved spices like cinnamon, cloves, mace, nutmeg and pepper not merely to flavour their food but also to preserve it. For centuries, these commodities had come overland from Asia to Europe along the Spice Road. But with the Portuguese discovery of the sea route to the East Indies via the Cape of Good Hope, new and irresistibly attractive business opportunities opened up. The Amsterdam Historical Museum is full of paintings that depict Dutch ships en route to and from the East Indies. One early example of the genre bears the inscription: 'Four ships sailed to go and get the spices towards Bantam and also established trading posts. And came back richly laden to... Amsterdam. Departed May 1, 1598. Returned July 19, 1599.' As that suggests, however, the round trip was a very long one (fourteen months was in fact well below the average). It was also hazardous: of twenty-two ships that set sail in 1598, only a dozen returned safely. For these reasons, it made sense for merchants to pool companies operating out of the major Dutch ports. However, in each case the entities had a limited term that was specified in advance - usually the expected duration of a voyage - after which the capital was repaid to investors. This business model should not suffice to build the permanent bases and fortification that were clearly necessary if the Portuguese and their Spanish allies were to be supplanted. Actuated as much by strategic calculations as by the profit motive, the Dutch States-General, the parliament of the United Provinces, therefore proposed to merge the existing companies into a single entity. The result was the United East India Company - the Vereenigde Nederlandsche Geoctroyeerde Oostindische Compagnie (United Dutch Chartered East India Company, or VOC for short), formally chartered in 1602 to enjoy a monopoly on all Dutch trade east of the Cape of Good Hope and west the Straits of Magellan.”

540 CATAPANI, Márcio Ferro. Títulos públicos: natureza jurídica e mercado-LFTs, LTNs, NTNs, TDAs e Tesouro Direto, p. 77. 
As empresas estatais, porém, podem ser a origem de desequilíbrios fiscais, quando tratadas de forma totalmente isolada do ente estatal controlador. Essa realidade foi vivida no Brasil durante boa parte do século XX, quando sequer se era capaz de obter uma visão global sobre o orçamento das empresas estatais, com o objetivo de avaliar eventual desequilíbrio entre receitas e despesas ${ }^{51}$.

A facilidade relativa de financiamento que encontram as empresas estatais conduz com frequência ao seu agigantamento, levando a uma alocação ineficiente de recursos pelos agentes financiadores, potencializando o risco fiscal a ser suportado pelo ente público controlador ${ }^{542}$.

A questão do impacto do regime de execução das empresas estatais sobre o endividamento público se coloca mais uma vez no contexto da chamada "fuga para o direito privado" 543 . Mais corretamente, pode-se dizer que o que se opera não é simples fuga para o direito privado, mas verdadeira superação da dicotomia entre direito público e privado, em ambos os casos se adotando conceitos e institutos extraídos do conjunto outrora pertencente ao outro grupo ${ }^{54}$. A utilização pelo Estado de instrumentos próprios do direito privado, como é o caso das empresas mercantis, é exemplo desta tendência que, com alguma frequência, ocorre também por razões fiscais.

Embora se trate de norma voltada à regular a organização da administração pública federal, o Decreto-lei n. 200/67 ainda é, juntamente à Constituição Federal de 1988, a principal referência legislativa a tratar da organização da Administração Pública no Brasil ${ }^{545}$.

541 LOCHAGIN, Gabriel Loretto. A unificação dos orçamentos públicos pela Constituição de 1988, p. 195: "O orçamento das empresas estatais não existiu, como um documento que consolidasse os gastos, até 1979, com a criação da Secretaria de Controle das Empresas Estatais (SEST), pelo Dec. 84.128, de 29.10.1979. Nem mesmo o governo tinha, até então, a informação precisa do total de suas empresas estatais."

542 SCHIRATO, Victor Rhein. As empresas estatais no direito administrativo econômico atual, p. 164: "Dessa zona cinzenta da legalidade da ação interventiva do Estado emerge um dos mais relevantes riscos relacionados às empresas estatais, qual seja o agigantamento indevido de sua atuação, sobretudo levando-se em conta a facilidade de financiamento de tais empresas, o que, a nosso ver, não foi objeto de muitas considerações doutrinárias no Direito brasileiro. Isto ocorre, pois, a doutrina do Direito Administrativo apresenta sempre uma preocupação contrária ao risco a que nos dedicaremos, na medida em que demonstra constante preocupação em assegurar privilégios e proteções às empresas estatais, o que apenas fomenta seu agigantamento desproporcional, sobretudo considerando-se a fragilidade da responsabilização de seu dono, decorrente da constante alternância de poder ínsita à democracia."

543 Sobre o tema ver ESTORNINHO, Maria João. A fuga para o direito privado... cit., passim.

544 COMPARATO, Fábio Konder; SALOMĀO FILHO, Calixto. O poder de controle na sociedade anôni$m a$, p. 137: "Sem querer repisar fatos universalmente conhecidos, a substituição do Estado liberal pelo Estado social não acarretou, como se imaginava a princípio, uma simples 'publicização' do direito privado, mas também uma 'privatização' do direito público. De um lado, o Estado passou a lançar mão de típicos instrumentos provados - como a sociedade mercantil e a empresa capitalista, de modo geral para desempenhar suas novas funções sociais.

De outro, - e é isto que nos interessa especialmente, no caso - a técnica do direito premial ou promocional substituiu os tradicionais comandos legais permissivos ou proibitivos, ao mesmo tempo em que os particulares passaram a ser responsabilizados pelo cumprimento de funçôes sociais, nova categoria dos agentes privados, investidos de funções sociais."

545 PINTO JÚNIOR, Mario Engler. Empresa Estatal: função econômica e dilemas societários, p. 92: "No Brasil, o modelo de direcionamento e fiscalização da atuação empresarial pública possui feição setorial e baseia-se essencialmente no princípio da supervisão ministerial, previsto no Decreto-lei federal n. 200, 


\section{•• Teoria jurídica do crédito público e operações estruturadas}

As empresas estatais gozam de autonomia patrimonial, como decorrência da sua personalidade jurídica autônoma em relação ao ente estatal que a institui. Pelo mesmo motivo, as empresas estatais gozam de autonomia gerencial, orçamentária e financeira, donde decorre a sua maior eficiência, ou donde, ao menos, se espera a obtenção de maior eficiência $^{546}$. Esta autonomia se revela juridicamente na ausência de dever de obediência da administração da empresa pública em relação a ordens emanadas da administração direta. A influência do governo sobre a empresa se dá, portanto, por meio da influência institucional ou moral sobre os seus órgãos societários ${ }^{547}$.

A contradição entre o interesse dos sócios no lucro, decorrente da própria estrutura empresarial da sociedade anônima, na forma do artigo $2^{\circ}$ da Lei das Sociedades Anônimas (LSA), e o interesse da comunidade, cuja observância se impõe no rigor do parágrafo único do artigo 116 da mesma lei, é elemento estrutural da visão institucionalista das sociedades estatutárias, como é o caso das sociedades anônimas. Contudo, isto fica ainda mais evidente no caso das sociedades de economia mista, posto que estas ainda devem atender ao disposto no artigo 238 da LSA.

Não cabe ao Estado interferir na atividade econômica com o objetivo de auferir rendimentos, posto que na forma da Constituição Federal o Estado apenas poderá interferir na atividade econômica para prestação de serviços públicos (art. 175) ou quando necessária aos imperativos da segurança nacional ou à proteção de relevante interesse coletivo (art. 173). Sendo assim, argumenta-se que o interesse público que orienta a criação da empresa estatal deveria sempre preponderar sobre o interesse de obtenção de lucro, pondo em conflito os interesses do Estado controlador e dos minoritários privados ${ }^{548}$.

de 25 de fevereiro de 1967, e largamente reproduzido em nível subnacional."

546 PINTO JÚNIOR, Mario Engler. Op. cit., p. 95: "A personalidade jurídica de direito privado confere ainda à empresa estatal elevado grau de autonomia gerencial, orçamentária e financeira, permitindo-lhe maior flexibilidade de atuação."

547 PINTO JÚNIOR, Mario Engler. Op. cit., p. 96: "O relacionamento entre as administrações direta e indireta não se baseia na lógica da subordinação hierárquica tradicional, vale dizer, não existe o dever jurídico de obediência entre autoridades da administração direta e dirigentes das entidades descentralizadas." E na p. 97: “(...) Nesse contexto, cabe à autoridade ministerial situada no plano externo à companhia definir as prioridades, sem interferir demasiadamente na administração quotidiana. Essa competência pode ser exercida através de canais institucionais ou de contatos informais." E, em seguida, na p. 109: "A rigor, os dirigentes de empresas estatais não devem obediência formal às ordens administrativas externas. Tais comandos possuem natureza de mera recomendação, salvo quando editados no exercício de competência regulatória legalmente reconhecida. A efetividade das prescrições emanadas do governo central depende essencialmente do grau de credibilidade da ameaça implícita de substituição dos gestores recalcitrantes, o que, por sua vez, está sujeito a todo tipo de injunçōes políticas."

548 PINTO JÚNIOR, Mario Engler. Op. cit., p. 372: "Em primeiro lugar, 'interesse público' não quer dizer interesse estatal, pois ambos podem não coincidir, necessariamente, sobretudo em país como o nosso, em que o Estado muito raramente foi representativo do povo, ou da sociedade civil. Ademais, a estrutura da sociedade de economia mista encerra, em si mesma, grave contradição. As companhias exploram, por definição legal, empresas lucrativas. Mas o regime econômico consagrado na Constituição não assina ao Estado, por função, produzir lucros. A legitimidade da ação estatal, ainda e sempre, é o serviço público, a produção de bens e serviços que não podem ser obtidos no regime da exploração privada, de modo eficiente e justo, sem discriminações entre os consumidores, de acordo com o princípio da deman- 
Neste contexto, questiona-se inclusive a função dos direitos políticos dos minoritários na sociedade de economia mista, colocando-se em perspectiva a possibilidade de outros instrumentos de investimento em lugar da participação acionária, de maneira a permitir o financiamento privado de empreendimentos públicos ${ }^{549-550}$.

A regra geral é de que o acionista controlador não responde pessoalmente pelas dívidas da sociedade. Essa responsabilização apenas ocorrerá em regra nos casos de violação dos deveres fiduciários tratados principalmente nos artigos 115, 116 e 117 da LSA ${ }^{551}$. No caso das empresas estatais, porém, essa regra é usualmente flexibilizada, com consequências fiscais por vezes não planejadas.

No caso das obrigações de titularidade das empresas estatais, encontra-se um dilema essencial. Se por um lado, a execução forçada da sociedade poderia colocar em risco o interesse público ligado à sua criação - especialmente nos casos de sociedades prestadoras de serviços públicos -, por outro, ausente essa possibilidade e também ausente a responsabilidade subsidiária do ente público controlador, estar-se-á diante de absoluta incapacidade dos credores de satisfação dos seus créditos. Esse tema se liga à execução forçada por meio da penhora e alienação em hasta pública de bens de empresas estatais, mas também à possibilidade de execução coletiva destas entidades, em regime falimentar.

É nesta ordem de considerações que, em face da previsão do artigo $173, \S 1^{\circ}$, II, da Constituição Federal de 1988, Mauro Rodrigues Penteado põe em dúvida a constitucionalidade da exclusão das empresas públicas do regime de falência e recuperação de empresas, que atualmente se lê no artigo 2o, I, da Lei de Recuperação de Empresas e Falências (LREF). Contudo, Penteado afirma que se poderia considerar constitucional tal dispositivo apenas sob o entendimento de que ao Estado caberia sempre responsabilidade subsi-

da solvável, como ocorre com a empresa capitalista. A função da empresa estatal não é a geração de receita sob a forma de lucro empresarial, mas a preservação da segurança nacional, ou a organização de setor que não possa ser desenvolvido com eficácia no regime de competição e de liberdade de iniciativa (Constituição Federal, art. 173). O dilema que se apresenta ao Estado, enquanto acionista controlador, é pois o de perseguir o interesse público antes e acima da exploração lucrativa - o torna sem sentido a participação societária do capital privado no empreendimento; ou dar lugar ao interesse público apenas quando este se coloca em conflito com objetivo normal de produção de lucros - o que infringe o princípio constitucional assinalado."

549 PINTO JÚNIOR, Mario Engler. Op. cit., p. 560: “Consideramos, outrossim, o caso das sociedades de economia mista. A sua criação só se justifica, evidentemente, para exercício de uma função eminentemente social, não fazendo sentido que o Estado procure obter ingressos públicos com a especulação lucrativa, que não é simples amortização de investimentos. Se na sociedade de economia mista só o Estado é empresário, por força de lei, por que teimar em manter a ficção do voto em assembleia e da partilha de lucros entre sócios? Se há interesse em atrair o investimento privado nesse tipo de atividade empresarial, como entendemos que existe, ele pode, perfeitamente, consubstanciar-se em papeis de renda fixa, com direito ao incremento dos chamados 'ganhos de capital', ou seja, sem as características de um empréstimo."

550 A respeito desse ponto, válida é a menção à disciplina das "partes beneficiárias” (artigo 46 e ss da LSA) para as companhias fechadas.

551 CAMPINHO, Sérgio. Curso de sociedade anônima, p. 279: "Por fim, não é demais registrar que o controlador não responde pessoalmente pelas obrigaçōes contraídas pela companhia, ressalvadas, por certo, as hipóteses de irregularidades, fraudes ou ilícitos." 


\section{•• Teoria jurídica do crédito público e operações estruturadas}

diária pelas obrigações de suas empresas públicas, independentemente da forma societária $\operatorname{adotada}^{552}$.

No caso das sociedades de economia mista, um elemento adicional deve ser avaliado, que consiste no fato de que, na redação original do artigo 242 da Lei n. 6.404/76, havia expressa menção à ideia de que as sociedades de economia mista não estariam sujeitas à falência, sendo os seus bens penhoráveis e executáveis e cabendo à pessoa jurídica controladora responder subsidiariamente pelas obrigaçōes da sociedade. Tal regra foi revogada pelo artigo 10 da Lei n. 10.303/01, após o que houve dúvida na doutrina a respeito da possibilidade ou não da aplicação da falência a essas empresas. $\mathrm{O}$ assunto foi novamente tratado no ano de 2005, a partir da exclusão expressa realizada pelo artigo $2^{\circ}$, I, da Lei 11.101/2005 553 .

A motivação para a existência do artigo 242 da Lei n. 6.404/76, declarada na exposição de motivos da lei, consistia no fato de que o interesse público ligado à sua criação não poderia ficar sujeito aos interesses privados que justificariam a administração, ainda que provisória, da entidade, por um terceiro, no interesse dos credores ${ }^{554}$. Em virtude dessa justificativa e da isonomia pretendida pela $\mathrm{CF} / 88$ no artigo $173, \S 1^{\circ}$, parte da doutrina entendia tal dispositivo como aplicável apenas às sociedades de economia mista prestadoras de serviços públicos, plenamente aplicável a falência às sociedades de economia mista que explorassem atividade econômica em sentido estrito ${ }^{555}$.

552 PENTEADO, Mauro Rodrigues. Artigo 20: itens 21 a 24, pp. 105-6. "Embora não tenha sido aprovada a lei a que se refere o art. $173, \$ 1^{\circ} \mathrm{da} C F$, estabelecendo o regime jurídico dessas sociedades controladas pelo Poder Público, os princípios maiores a que estão submetidas ... colocam em dúvida a constitucionalidade do dispositivo comentado, embora sempre se possa sustentar que a responsabilidade subsidiária do acionista controlador o tornaria compatível com o comando constitucional, mormente porque a lei disciplinadora que está por vir deverá regular as relações da empresa pública com o Estado e a sociedade (...) Sendo o capital da empresa pública de exclusiva titularidade do Estado, é este que deve adotar as providências necessárias à superação da crise econômico-financeira da empresa pública, bem como diligenciar para que cumpra pontualmente as suas obrigaçôes, cabendo-lhe responder subsidiariamente pelos pagamentos não realizados, inclusive em juízo." No mesmo sentido SCHIRATO, Victor Rhein. As empresas estatais no direito administrativo econômico atual, p. 123: "Logo, uma primeira conclusão a que se consegue chegar sobre o tema da falência nas empresas estatais é a de que a exclusão operada pelo legislador do regime de execução coletiva implicou ipso iure uma imposição de responsabilidade subsidiária ao Estado controlador da empresa estatal, visto que não há como conceber que não haja qualquer instrumento jurídico garantidor da solvência de tais entidades."

553 PENTEADO, Mauro Rodrigues. Op. cit., p. 106.

554 CARVALHOSA, Modesto; EIZIRIK, Nelson. A nova lei das sociedades anônimas, pp. 365-6: "Essa imunidade prevista no revogado art. 242 encontrava o seu fundamento na necessidade de ser preservado o interesse publico que presidiu a instituição da sociedade de economia mista; com efeito, entendia-se não se justificar que os credores, e não os representantes do Estado, passassem, em caso de falência, a dirigir as atividades da companhia de economia mista."

555 Ver GRAU, Eros Roberto. Execução contra estatais prestadoras de serviço público. Revista trimestral de direito público, p. 99: "Da mesma forma, no parágrafo 1º, do artigo 173 a expressão conota atividade econômica em sentido estrito: determina fiquem sujeitas ao regime próprio das empresas privadas, inclusive quanto às obrigaçôes trabalhistas e tributárias, a empresa pública, a sociedade de economia mista e outras entidades que atuem no campo da atividade econômica em sentido estrito; o preceito, a toda evidência, não alcança empresa pública, sociedade de economia mista e entidades (estatais) que 
Logo após a revogação do artigo 242, Modesto Carvalhosa entendeu ser plenamente aplicável o regime falimentar às sociedades de economia mista, com fundamento no fato de que a revogação do dispositivo fora proposto no Projeto de Lei n. 3.115/97, sob o argumento de que o tratamento diferenciado dado às sociedades de economia mista violaria a $\mathrm{CF} / 88$ no seu artigo $173, \$ 10^{5556}$. Ao mesmo tempo, entendeu o autor que, com isso, desapareceria a figura da responsabilidade subsidiária ${ }^{557}$, exceto nos casos em que as obrigaçôes tivessem sido contraídas durante a vigência do artigo $242^{558}$.

A discussão voltou à tona com a aprovação da Lei n. 11.101/05, que, em seu artigo 2o, I, expressamente excluiu do regime falimentar e de recuperação as empresas públicas e sociedades de economia mista. Já sob a nova vedação, Haroldo Verçosa entendeu ser inconstitucional a limitação do regime falimentar às empresas estatais, sob o argumento de que não se coadunaria com o princípio da moralidade administrativa permitir a existência de empresa subcapitalizada atuando junto ao mercado privado. Assim, embora reconhecesse a impossibilidade de aplicação da recuperação judicial, entendeu possível a declaração de falência, mantendo-se a responsabilidade subsidiária e ilimitada dos acionistas controladores por prejuízos causados a fornecedores e demais acionistas ${ }^{559}$.

prestam serviço público." Este é também o entendimento de DI PIETRO, Maria Sylvia Zanella. Direito administrativo, p. 444-5, na medida em que afirma que o artigo $173 \mathrm{da} C F / 88$ apenas se aplicaria à intervenção do Estado na atividade econômica em sentido estrito, aplicando-se aos serviços públicos o artigo 175 da CF/88: "A distinção ganha relevo em matéria de interpretação das leis. Quando se trata de atividade econômica exercida pelo Estado com fundamento no artigo 173, que determina a sujeição ao direito privado, este é que se aplicará, no silêncio da norma publicística; por outras palavras, presume-se a aplicação do regime de direito privado, só derrogado por norma expressa, de interpretação estrita. Quando, porém, o Estado fizer a gestão privada do serviço público, ainda que de natureza comercial ou industrial, aplicam-se, no silêncio da lei, os princípios de direito público, inerentes ao regime jurídico administrativo." Cite-se ainda lição de ATALIBA, Geraldo. Patrimônio administrativo - empresas estatais delegadas de serviço público - regime de seus bens - execução de suas dívidas, p. 23: "Pelos princípios da continuidade e da supremacia do interesse público, os bens da empresa estatal prestadora de serviço público, que estão afetos ao serviço público, não podem ser penhorados." No mesmo sentido e antes mesmo da CF/88 BANDEIRA DE MELLO, Celso Antônio. Regime jurídico das empresas estatais, p. 190: "No tocante à penhora de bens, eu não concebo a penhora de bens imediatamente aplicáveis ao serviço público. Mas concebo perfeitamente a penhora de bens que estejam aplicados simplesmente à exploração de atividade econômica. Se aquela empresa é insuficiente economicamente, como qualquer outra seria, que seus bens sejam penhorados e que ela seja executada como uma outra qualquer."

556 CARVALHOSA, Modesto; EIZIRIK, Nelson. A nova lei das sociedades anônimas, p. 367: "Com a revogação do art. 242 da Lei n. 6.404/76, as sociedades de economia mista passam, inequivocamente, a submeter-se ao processo de execução coletiva, sem qualquer imunidade."

557 CARVALHOSA, Modesto; EIZIRIK, Nelson. Idem, ibidem: "Em nenhum momento foi discutida [na tramitação do projeto que culminou na Lei 10.303/01] no Congresso a questão referente à responsabilidade subsidiária do ente público controlador das sociedades de economia mista, que deverá desaparecer com a revogação integral do art. 242 da Lei das S/A."

558 CARVALHOSA, Modesto; EIZIRIK, Nelson. Op. cit., p. 371: "Consequentemente, o ente controlador da sociedade de economia mista continua a responder subsidiariamente pelas obrigaçôes por ela contraídas na vigência do art. 242 da Lei das S/A."

559 VERÇOSA, Haroldo Malheiros Duclerc Verçosa. Curso de direito comercial - volume 3, pp. 690-1: "O assunto não se esgota na aplicação pura e simples da lei falimentar, na ausência de dispositivo próprio na 


\section{•• Teoria jurídica do crédito público e operações estruturadas}

De nossa parte, acolhemos posicionamento majoritário na doutrina ${ }^{560}$ que consiste em distinguir o regime de bens e de execução aplicável às empresas estatais prestadoras de serviços públicos e as que exerçam atividade econômica em sentido estrito ${ }^{561}$. No primeiro caso, o princípio da continuidade do serviço público limita a pretensão do particular decorrente do seu direito de crédito contra a empresa estatal, devendo a execução forçada incidir apenas sobre bens não afetados à prestação do serviço público delegado à empresa. Não havendo tais bens, a execução deve ser feita sob regime de precatórios, primeiramente de modo segregado, formando-se fila especial de credores/precatoristas próprios da entidade, e em havendo caso de insolvência, consolidando-se os precatórios devidos pela entidade com os precatórios devidos por seu controlador, respeitada a ordem cronológica da lista consolidada. Entendemos não ser possível, portanto, a falência de tais entidades, em respeito à titularidade estatal dos serviços públicos e a sua necessária continuidade.

LSA. Isto porque, manifestando opinião pessoal reconhecidamente minoritária e polêmica, ao escrever em passado recente a respeito da insolvência das empresas públicas e sociedades de economia mista, entendemos que, apesar da exclusão legal presente na LREF, então por nos julgada inconstitucional, elas estão sujeitas à falência e não têm direito à recuperação judicial.Isto porque, em determinada situação concreta na qual se verifique algum interesse do Estado em fazer minguar até a inadimplência uma sociedade de economia mista, com prejuízo para seus credores e acionistas minoritários, a supressão da responsabilidade subsidiária do controlador não pode ser escudo impenetrável contra o Estado e os administradores por ele eleitos para tal companhia de economia mista. Neste caso, a moralidade do direito administrativo somente estaria atendida com o reconhecimento da permanência da aludida responsabilidade do controlador e dos administradores por perdas e danos causados aos acionistas e a terceiros quando caracterizados abuso de poder de controle e omissão no exercício dos cargos administrativos. No caso acima, insistindo o Estado em não capitalizar a sociedade de economia mista sob seu controle, na justa medida das necessidades financeiras para o prosseguimento de sua atividade e pagamento dos credores, caberia a decretação de sua falência, respondendo o controlador de forma ilimitada pelos prejuízos causados aos credores feito para participação em tal empreendimento conjunto."

560 SCHIRATO, Victor Rhein. As empresas estatais..., p. 69: “... Tradicionalmente, a doutrina distingue o regime jurídico das empresas estatais conforme as atividades por elas empreendidas, de tal sorte que às empresas estatais prestadoras de serviços públicos seria aplicável um regime predominantemente de Direito público, ao passo que às empresas exploradoras de atividades econômicas seria apropriado um regime predominantemente de Direito privado, aproximando-as mais das empresas privadas do que do Estado.

A ratio da distinção seria a necessidade de conferência de benefícios e prerrogativas especiais ao serviço público, que não seriam extensíveis às atividades econômicas. Contudo, com a aproximação cada vez maior dos serviços públicos às demais atividades econômicas, a razão da distinção perde o sentido, visto que as empresas prestadoras de serviços públicos passam, em diversos casos, a estar em regime de competição com outras empresas, em um espaço liberalizado, como ocorre com qualquer outra atividade econômica.” (p. 69)

561 Também a jurisprudência se inclina para esse entendimento, conforme se verifica nos precedentes RE 220.906-DF, de Relatoria do Ministro Maurício Corrêa, relativo a Empresa Brasileira de Correios e Telégrafos (ECT) e AC 669-SP, de Relatoria do Ministro Carlos Britto, envolvendo a Companhia Metropolitano de São Paulo. Deve-se reconhecer, porém, a existência de críticas a essa dicotomia, conforme SCHIRATO, Victor Rhein. As empresas estatais..., p. 56: "Ocorre, todavia, que as noções estanques de serviço público e de atividade econômica são cada vez mais postas em jogo, de forma que passa a não ser mais perfeitamente possível em diversos casos incluir a função de uma empresa estatal no campo dos serviços públicos ou de outras atividades econômicas. Ademais, a realidade fática passa a demonstrar a existência de empresas estatais que não prestam serviços públicos nem exploram outra atividade econômica, realizando funções tipicamente autoritárias ou burocráticas atribuídas exclusivamente ao Estado, mas não passíveis de inclusão em qualquer das categorias mencionadas." 
Por outro lado, entendemos possível a penhora de bens e também a falência de empresas estatais que exerçam atividades econômicas em sentido estrito, por decorrência da expressa previsão constitucional contida no artigo $173, \$ 1^{\circ}$, II, da CF/88, que não autoriza o gozo de benefícios pelas empresas estatais não extensíveis às empresas privadas ${ }^{562}$. Porém, ao contrário de Verçosa, não entendemos cabível, neste caso, a responsabilização subsidiária do ente controlador, caso se tenha optado por forma societária que preveja responsabilidade limitada, exceto nos casos de fraude à lei, ao contrato ou estatuto social, de conflito de interesses ou de abuso de poder de controle. Isto, pois, em nossa visão, tal responsabilidade subsidiária configuraria benefício extra às estatais, incrementando o seu crédito na forma de uma "fiança pública perpétua" conferida pelo Estado, que é reconhecidamente o devedor de menor risco econômico dentre todos, em razão da sua perenidade, da sua capacidade de tributar aos seus cidadãos e, em última instância, em razão do seu poder de emissão de moeda.

É conhecida a distinção existente entre propriedade e controle nas sociedades anôni$\operatorname{mas}^{563}$, o que pode levar com frequência a situaçõoes de conflito de interesses ${ }^{564}$. Para lidar com essa situação, sem inibir a dissociação entre propriedade e controle, que auxiliam na formação do capital produtivo, a legislação societária brasileira traz conjunto de regras voltadas a coibir o abuso do poder de controle e a existência de conflito de interesses ${ }^{565}$.

Embora relevante para definir a existência do poder de controle, a maioria do capital votante não é determinante para definição do acionista controlador. Este, deve deter, por força do artigo 116 da Lei n. 6.404/76, além de direitos de sócio que assegurem de modo permanente a maioria dos votos em assembleia geral, também o uso efetivo deste poder para dirigir as atividades sociais. Assim, nota-se que, nem a LSA exige mais de $50 \%$ do capital votante, nem considera bastante tal fato para que se possa falar em poder de controle, ainda que se possa, quanto ao acionista majoritário, aplicar os deveres relativos ao acionista controlador independentemente do exercício de fato do poder de controle ${ }^{566}$.

562 Neste sentido o precedente contido no RE 599.628-DF, Relator para o Acórdão Ministro Aires Britto.

563 SALOMÃO FILHO, Calixto. O novo direito societário, p. 141: "É conclusão pacífica da investigação societária moderna a dissociação operada pela economia capitalista entre propriedade e controle. $\mathrm{Na}$ medida em que a organização societária torna-se mais complexa e profissional, tanto menor torna-se a influência do acionista individual, transformado em mero investidor, nas decisões societárias." Também em COMPARATO, Fábio Konder; SALOMÃO FILHO, Calixto. O poder de controle na sociedade anônima, pp. 51-2. O mesmo em CAMPINHO, Sérgio. Curso de sociedade anônima, p. 275, sempre com referências à lição de Berle e Means (BERLE, Adolf Augutus; MEANS, Gardiner C. The modern corporation and private property. New York: Macmillan Company, 1933).

564 SALOMÃO FILHO, Calixto. O novo direito..., p. 142: "A potencial contraposição de interesses que pode derivar de uma tal atuação é óbvia. Quanto menor a participação percentual do controlador na sociedade controlada, maior será seu lucro em uma operação entre a sociedade e ele próprio (ou pessoas a ele ligadas) que seja feita em condições desvantajosas para a sociedade e favoráveis a ele."

565 Ver, por exemplo, artigos 115, 117, 154, 155 e 156 da Lei n. 6.404/76.

566 SALOMÃO FILHO, Calixto. Op. cit., p. 144: “(...) Em caso de controle majoritário, claramente irrelevante é o uso efetivo do poder: o acionista terá status de controlador e as responsabilidades dele decorrentes, seja por ação ou por omissão.

Assim, a conclusão deve necessariamente ser no sentido de que o núcleo da definição de controlador reside no poder de determinar o sentido das deliberações sociais e da atividade social, independentemente 


\section{•• Teoria jurídica do crédito público e operações estruturadas}

Essa menção torna-se relevante em face da possível crítica ao anacronismo da definição de sociedade de economia mista prevista no Decreto-Lei n. 200/67, com redação dada pelo Decreto-Lei n. 900/69, como aquela criada para o exercício de atividade econômica em que a maioria das açóes com direito a voto sejam detidas pelo Estado. A mencionada legislação adota critério formal de controle, filiado à espécie de controle majoritário ${ }^{567}$, ultrapassada pelo teor do citado artigo 116 da Lei n. 6.404/76, que reconhece a possibilidade de exercício de poder de controle por diferentes meios ${ }^{568}$.

No mesmo problema incorreu o legislador ao aprovar a Lei n. 13.303/2016, na medida em que adotou, no artigo 4o , o mesmo critério de controle majoritário para a definição de sociedade de economia mista. Na prática, nada obsta, portanto, que se crie empresa estatal controlada pelo ente público por meio de acordo de acionistas, ação minoritária preferencial que confira o poder de nomear administradores, ou qualquer outra forma de exercício de poder de fato. Porém, a essa empresa formalmente não se aplicarão as regras restritivas aplicáveis às sociedades de economia mista previstas na Lei n. 13.303/2016 ou em outras leis, muito embora materialmente em nada difiram das sociedades de economia mista, que assim são classificadas por contarem com mais de $50 \%$ do seu capital votante de propriedade do ente público.

É comum associar o controle gerencial ao absenteísmo dos sócios, diante de elevada dispersão acionária, cabendo, nesse contexto, aos administradores o controle, em razão de estratégias como a definição de amplas competências por meio do estatuto social, ou simplesmente a outorga de procuração aos administradores para a votação em assembleia de acionistas $^{569}$. Contudo, outra origem pode haver para o exercício do controle gerencial, qual seja aquela fundamentada na existência de um corpo estável de funcionários altamente especializados, cujo conhecimento sobre os negócios da empresa é muito superior ao dos acionistas, ainda que majoritários. Neste contexto específico, que frequentemente se pode encon-

de qual seja a origem desse poder." Sérgio Campinho deixa bem clara a distinção entre as figuras do controlador e do sócio majoritário em CAMPINHO, Sérgio. Op. cit., p. 276: "Tendo ele [acionista] a maioria de votos e o poder de eleição da maior parcela dos administradores, mas não fazendo uso de fato dessas prerrogativas, não será controlador, mas sim acionista majoritário, simplesmente. O controlador, portanto, deverá impor à sociedade a preponderância de sua vontade utilizando-se, efetivamente, dos poderes de que desfruta para conduzir os negócios e eleger a maioria dos administradores."

567 Sobre as formas de controle ver COMPARATO, Fábio Konder; SALOMÃO FILHO, Calixto. O poder de controle..., pp. 51-105.

568 SCHIRATO, Vitor Rhein. As empresas estatais..., p. 51: "Assim, o controle do Estado sobre as sociedades de economia mista deve ser considerado não apenas decorrente da propriedade da maioria das ações com direito a voto, mas também de qualquer outro mecanismo legal que assegure ao Estado a existência de um poder de controle." No mesmo sentido, ALMEIDA, Fernando Dias Menezes de. Tratado de direito administrativo: controle da administração pública e responsabilidade do Estado, p. 363: "Aliás, do ponto de vista empresarial, é anacrônica a opção legislativa pelo critério de participação minoritária de capital privado nas 'ações com direito a voto', como suficiente significativo do controle estatal."

569 CAMPINHO, Sérgio. Op. cit., p. 274: "O controle administrativo ou gerencial pressupõe uma pulverização acionária, resultado de um nível de dispersão tão elevado das ações, que o controle passa a ser detido pelos administradores, os quais, através do mecanismo do voto por procuração, acabam se perpetuando na direção social. É, assim, uma modalidade de controle interno, totalmente dissociada da propriedade acionária. Explora-se, ao máximo, o absenteísmo do corpo de acionistas.” 
trar nas empresas estatais, não é difícil se verificar a orientação dos negócios sociais antes para a preservação de interesses corporativos do que para os interesses sociais ${ }^{570}$ na forma prevista no artigo 238 da LSA. Trata-se de uma modalidade, pode-se dizer "desviada", do controle gerencial, o que chamaríamos de "controle gerencial corporativista" 571.

Destarte, conclui-se que a empresa estatal lida com ambiguidade importante quando se trata da possibilidade de formação de contingências inadequadamente apresentadas nas estatísticas fiscais. Por um lado, o excesso de controles por parte da administração direta tende a impactar negativamente na eficiência almejada. Por outro lado, a autonomia exacerbada da empresa estatal pode ser desviada para o cumprimento de uma agenda própria, muitas vezes corporativista, desalinhada dos interesses estratégicos do ente estatal controlador $^{572}$.

É também possível que o poder de controle seja exercido, ou ao menos influencia$\mathrm{do}^{573}$, por agentes externos, o que é comum nos casos de contratos de financiamento garantidos por penhor ou alienação fiduciária de ações que compõem o bloco de controle, conforme autorizado pelo artigo 113 da LSA ${ }^{574}$. Não é possível, porém, dar operatividade a tais dispositivos nos casos envolvendo sociedades de economia mista, seja pela impossibilidade de alienação das açôes de propriedade do Poder Público sem autorização legal, seja pela impossibilidade de transferir aos credores a decisão a respeito dos destinos da companhia, ligada que está ao atingimento do interesse público.

570 COMPARATO, Fábio Konder; SALOMÃO FILHO, Calixto. O poder de controle..., p. 72: "Para ele [ex-trotskista James Burnham], o Estado empresário seria a forma durável de organização estatal nas sociedades industrializadas. A propriedade estatal dos meios de produção conduziria à emergência de um poderoso estamento de técnicos gerenciais. Ora, exercendo esses técnicos funções indispensáveis na sociedade, e tendo acesso ao controle dos meios de produção, passariam, inevitavelmente, a agir nos seus próprios interesses. Milovan Djilas, outro ex-marxista, não se afastou muito desse esquema ao denunciar, no pós-guerra, a nova classe tecnocrática."

571 COMPARATO, Fábio Konder; SALOMÃO FILHO, Calixto. Op. cit., p. 71: "O último tipo de controle, na classificação de Berle e Means, é o administrativo ou gerencial (management control), isto é, aquele não fundado na participação acionária mas unicamente nas prerrogativas diretoriais. É o controle interno totalmente desligado da titularidade das açôes em que se divide o capital social. Dada a extrema dispersão acionária, os administradores assumem o controle empresarial de facto, transformando-se num órgão social que se autoperpetua por cooptação."

572 PINTO JÚNIOR, Mario Engler. Empresa Estatal: função econômica e dilemas societários, p. 100: "O isolamento político e o excesso de autonomia favorecem a feudalização da empresa estatal, enquanto que as ingerências externas e o peso exagerado dos controles podem anular as vantagens associadas ao dinamismo e flexibilidade do modelo de gestão empresarial."

${ }^{573}$ CAMPINHO, Sérgio. Op. cit., p. 273: “(...) parece-nos haver uma distinção qualitativamente ponderável entre o poder de controle e o poder de influir, próprio do que se vem chamando de controle externo. Este, sustentamos, não se pode caracterizar como controle acionário; manifesta, sim, um processo de influência sobre o controle propriamente dito."

574 CAMPINHO, Sérgio. Op. cit., p. 272: "Geralmente, a figura deriva de uma situação de endividamento da companhia ou de seu bloco de controle. Diante dessa dependência econômico-financeira, a sociedade ou o acionista controlador, por força de disposição contratual, asseguraria ao agente estranho à companhia uma influência em certas decisōes societárias. Resulta, pois, essa posição dominante, não de uma configuração própria ao Direito Societário, mas de vínculos externos, geralmente de natureza contratual." 


\section{•• Teoria jurídica do crédito público e operações estruturadas}

A partir da leitura do artigo 116 da LSA, nota-se claramente a existência de deveres fiduciários gerais do acionista controlador para com os demais acionistas e também para com a comunidade, o que inclui evidentemente funcionários e fornecedores da companhia ${ }^{575}$.

Considerando a diversidade de interesses que se aglutinam na empresa estatal e disputam seu espaço ao lado do interesse público que justifica a instituição da entidade, as empresas estatais apresentam-se como bastante relevantes para os resultados fiscais do ente controlador devido ao fato de que, com frequência, dependem de recursos transferidos pelo ente público para a sua manutenção ou para investimentos. Assim, eventuais dívidas ou contingências mantidas por tais empresas podem vir a afetar o desempenho fiscal do Estado. A não inclusão das estatais nas estatísticas fiscais, portanto, contribui, em diversos casos, para uma interpretação inadequada da situação fiscal de um determinado ente ${ }^{576}$.

Vale chamar atenção ao fato de que a utilização de empresas estatais e de instrumentos financeiros para desviar de limites ao crescimento do endividamento público não é novidade, sendo estratégia comum, nos países em que adotam tais limites ${ }^{577}$.

A respeito deste ponto, a legislação brasileira prevê a aplicação das regras de responsabilidade fiscal às empresas estatais dependentes, de maneira a evitar desajustes cujo impacto deva ser suportado pelo ente estatal ${ }^{578}$. Contudo, a Lei de Responsabilidade Fiscal conceitua como empresa estatal dependente aquela que receba "recursos financeiros para pagamento de despesas com pessoal ou de custeio em geral ou de capital, excluídos, no último caso, aqueles provenientes de aumento de participação acionária” (art. 2º, III). Neste contexto, interessante questão que se coloca diz respeito às empresas que recebam recursos a título de contrapartida pela prestação de serviços ou venda de produtos. Neste caso, como o recurso não é repassado com a finalidade de pagamento de despesas de pessoal ou custeio, não se poderá falar em dependência.

Nada obstante, a questão deixa de ser tão clara no caso de a totalidade, ou a quase totalidade, das receitas da empresa estatal ser originada em contratos com o ente estatal controlador, sem que haja, por parte de empresa e contratante, um adequado controle do custo-benefício da contratação, com base em referência de preços de mercado. Nesta situação, a probabilidade de haver subsídio público a uma empresa estatal ineficiente é elevada, o que aproximaria a entidade da situação de dependência financeira. Também nesta situação a legislação brasileira deveria invocar a aplicação das regras de responsabilidade fiscal,

75 SALOMÃO FILHO, Calixto. O novo direito..., p. 194.

576 OLIVEIRA, Weder de. Curso de responsabilidade fiscal: direito, orçamento e finanças públicas, p. 106: "Outra razão para a inclusão das estatais é que, como sustenta Vito Tanzi, muitas dessas empresas sobrevivem porque o governo está lá para fornecer fundos e pode-se acrescentar que aquilo que elas produzem e a maneira como o fazem com certeza são influenciados por sua qualidade de setor público. Tanzi, contudo, aceita que empresas públicas que são administradas com critérios de eficiência, e que podem ser tão eficientes quanto as privadas, possam ser excluídas do cálculo do déficit."

577 TER-MINASSIAN, Teresa; CRAIG, Jon. Control of subnational government borrowing, p. 166.

578 Regras essas relativas a limites de endividamento, concessão de garantias, despesas de pessoal, despesas de caráter continuado, entre outras, na forma da Lei Complementar n. 101/2000. 
o que até o momento não faz expressamente, cabendo ao aplicador da lei interpretar teleologicamente o artigo $2^{\circ} \mathrm{da}$ LRF, de maneira a enquadrar tais empresas como dependentes.

É fato que, em situação normal, os limites da LRF não se aplicam sobre as empresas estatais não dependentes que, assim, estão livres para buscar a estratégia de endividamento que entenderem mais adequada ao seu plano de negócios, tanto no que se refere à obtenção de capital de giro, quanto no referente às dívidas destinadas ao financiamento de despesas de investimentos. É evidente, porém, que também as empresas estatais não dependentes enfrentam restrições de ordem creditícia, isto é, ligadas à oferta de crédito suficiente para o atendimento da sua demanda.

Ao mesmo passo em que a garantia implícita do ente público controlador poderia favorecer a oferta de crédito a empresas estatais, de modo contrário, vislumbra-se a aplicação também, às empresas estatais não dependentes, das normas de contingenciamento de crédito do setor público, que até o exercício de 2017 estavam dispostas na pela Resolução n. 2.827/2001 do Conselho Monetário Nacional, o que, de alguma forma, já refletia a percepção da necessidade de controle da oferta de crédito ao setor público por meio de empresas estatais, ainda que não dependentes ${ }^{579}$. Em 2018 a mencionada Resolução deu lugar à Resolução n. 4.589/2017, do mesmo CMN, mantendo, porém, a sua abrangência às operações realizadas com empresas estatais ainda que não dependentes.

Voltando ao argumento central do presente item deste trabalho, pode-se concluir, portanto, que, no caso das empresas estatais que exerçam atividade econômica em sentido estrito, em regime de concorrência, a doutrina tem aceitado a penhorabilidade de seus bens, assim como a possibilidade de sua falência, sob o argumento da inconstitucionalidade do artigo $2^{\circ}$, I, da LREF, que expressamente exclui as empresas estatais do regime falimentar. Tal entendimento se sustenta sobre o artigo 173, $\$ 1^{\circ}$, II, da Constituição Federal.

Ainda assim, a existência de uma garantia implícita de cobertura, especialmente no caso de grandes empresas estatais com longa tradição e corpos funcionais estáveis e politicamente fortes, pode favorecer a existência de uma tendência ao superendividamento, que terá de ser integralmente suportado pelo ente controlador, sem que tenha sido anteriormente mapeado e acompanhado com base na legislação financeira nacional. Esse suporte ocorre não por força de obrigação jurídica, mas por força de pressão política, dando origem ao chamado "risco moral".

No caso das empresas estatais prestadoras de serviços públicos, em função do princípio da continuidade dos serviços públicos, doutrina e jurisprudência têm se inclinado a rejeitar a possibilidade de penhora de bens das estatais, especialmente quando diretamente ligados ao serviço público em questão, afastando igualmente a possibilidade de falência destas entidades. Neste caso, o silêncio da legislação deve ser compreendido como necessidade de aplicação do regime de precatórios do artigo 100 da Constituição Federal, mantendo-se a responsabilidade subsidiária do ente público concedente do serviço público prestado pela estatal.

579 PINTO JÚNIOR, Mario Engler. Op. cit., p. 116: “Já as empresas não dependentes sofrem poucas restriçōes operacionais por força da Lei de Responsabilidade Fiscal, embora sejam fortemente contingenciadas na sua capacidade de tomar empréstimos junto ao setor financeiro nacional." 


\section{•• Teoria jurídica do crédito público e operações estruturadas}

Fica clara, por conseguinte, a lacuna existente na legislação financeira relativa à responsabilidade fiscal, considerando-se que as empresas estatais prestadoras de serviços públicos, sejam ou não dependentes nos termos da LRF, poderão representar contingência fiscal para o ente controlador, a ser assumida em momento futuro. Sendo assim, mister se faz a releitura do conceito de empresa estatal dependente para incluir igualmente as empresas prestadoras de serviços públicos, independentemente de receberem ou não recursos para pagamento de despesas de custeio ou de pessoal, consolidando-se o seu nível de dívida e de despesas monitoradas com os do seu ente controlador.

Ao lado das empresas estatais já tradicionais, encontram-se as chamadas empresas público-privadas, que são aquelas formadas a partir da participação societária estatal sem detenção do controle societário, mas visando ao atingimento de algum objetivo de política pública ${ }^{580}$.

Nas empresas público-privadas não deve haver dúvidas quanto ao regime jurídico a ser aplicado, que será sempre o de direito privado. Contudo, também essas empresas suscitam problemas relativos à sustentabilidade fiscal, na medida em que os riscos de negócio por parte do Estado, sobretudo na seleção do parceiro, precisam estar adequadamente mapeados e confrontados com os benefícios da adoção dessa figura societária.

Não se é possível exigir procedimento licitatório, na maior parte dos casos, para seleção de parceiro privado para empreendimento conjunto (“joint venture") ${ }^{581}$. Isso, pois a realização de negócio economicamente vantajoso envolverá, frequentemente, a necessidade de negociação flexível sobre aspectos estratégicos da operação, apresentando-se tal negociação como incompatível com procedimento usual de seleção de propostas decorrente da Lei n. 8.666/93582. Daí não decorre que a seleção seja desprovida de motivação ou

580 ARAGÃO, Alexandre Santos. Empresa público-privada: "Essa participação, ao contrário daquelas furtivas e temporárias (exemplo: herança jacente, penhora/adjudicação de cotas etc.), dá-se, apesar de não ser majoritária, com vistas à realização de algum interesse público, podendo se dar tanto através de empresas integrantes da Administração Indireta e, portanto, controladas pelo Estado, como, o que é menos comum, diretamente pelo próprio Estado.

Empresas público-privadas seriam, assim, as sociedades comerciais privadas com participação estatal, direta ou indireta, minoritária com vistas à realização de determinado objetivo público incumbido pelo ordenamento jurídico ao Estado."

581 A Lei n. 13.303/2016 expressamente reconheceu este fato no art. $28, \S 3^{\circ}$, I, e $₫ 4^{\circ}$, afastando a necessidade de licitação no caso de parcerias estratégicas.

582 ARAGÃO, Alexandre Santos. Op. cit: "Ao celebrar um contrato de sociedade, não está o Poder Público contratando a realização de uma obra ou de determinado serviço, mas sim se associando a um terceiro para com ele dividir obrigações e os lucros do negócio, em proporções pré-definidas. O normalmente longo, flexível e complexo processo de negociação que envolve os potenciais interessados em formar uma sociedade é incompatível com modelos estanques e procedimentalizados de seleção. Tanto é assim, que, mesmo quando a negociação envolve apenas agentes inteiramente privados, as negociações seguem termos bem fluidos, e geralmente secretos. O que não quer dizer que, ressalvadas as necessidades de sigilo comercial de praxe, a seleção seja transparente, racional economicamente e motivada.

Em sendo a affectio societatis essencial para a constituição da Sociedade de Propósito Específico, e constituindo esta uma relação de afinidade entre as partes para a realização de um objetivo comum, torna-se evidente que não há como submeter esse tipo de vínculo à prévia licitação, já que não há como indicar elementos objetivos para a escolha a ser procedida." 
critérios objetivos, mas tão somente que sejam dispensáveis os procedimentos ordinários de licitação e contratação.

O artigo 37, XXI, da Constituição Federal expressamente prevê que "ressalvados os casos especificados na legislação, as obras, serviços, compras e alienaçôes serão contratados mediante processo de licitação pública que assegure igualdade de condiçóes a todos os concorrentes, com cláusulas que estabeleçam obrigaçôes de pagamento, mantidas as condições efetivas da proposta, nos termos da lei, o qual somente permitirá as exigências de qualificação técnica e econômica indispensáveis à garantia do cumprimento das obrigações." Ou seja, o artigo 37, XXI expressamente prevê a exigência de licitação apenas para a contratação de (i) obras; (ii) serviços; (iii) compras; e, (iv) alienações. A esse rol o artigo 175 da Constituição acrescenta os casos de permissão e concessão de serviços públicos, sendo a lista refletida no artigo $2^{\circ}$ da Lei n. 8.666/93, que prevê que "as obras, serviços, inclusive de publicidade, compras, alienaçôes, concessões, permissões e locações da Administração Pública, quando contratadas com terceiros, serão necessariamente precedidas de licitação, ressalvadas as hipóteses previstas nesta Lei”. A leitura de tais dispositivos deixa evidente o fato de que nem todas as contrações realizadas pelo Poder Público serão precedidas de licitação.

Outro caso que se faz necessário analisar consiste na criação de empresas estatais com a finalidade de constituir garantias em contratos públicos, sobretudo, em contratos de longo prazo como são os contratos de parcerias público-privadas. Para que empresas estatais possam ser utilizadas para garantia de contratos de PPPs, é preciso que tenham sido criadas com a finalidade específica de garantir tais contratos. A esse respeito, é preciso aclarar que "finalidade específica" não se confunde com "finalidade exclusiva", sendo suficiente que o objeto social preveja expressamente o objetivo de garantir contratos de PPPs, ainda que em meio a outras competências ${ }^{583}$.

Por tudo o quanto exposto, porém, a adoção de tal instrumento jurídico deve ser analisada cuidadosamente de maneira a observar se se trata exclusivamente de estratégia para afastar o regime jurídico aplicável aos bens públicos na contrataçãa ${ }^{584}$, bem como para observar eventuais contingências que podem surgir para o ente público, em decorrência da avaliação pouco cuidadosa de projetos a serem garantidos pela empresa, especialmente nos casos em que a empresa estatal garantidora não se restrinja a atuar em projetos de iniciativa do seu ente instituidor.

583 SCHIRATO, Vitor Rhein. Os sistemas de garantia nas parcerias público-privadas: "Nos termos do inciso V do artigo $8^{\circ}$ da Lei n. 11.079/04 é lícito, ainda, à Administração Pública recorrer a entidades da Administração Indireta para a concessão de garantias nos contratos de PPP, desde que tais entidades tenham sido constituídas com a finalidade específica de garantir as obrigações do Poder Público oriundas do contrato de PPP.”

584 SCHIRATO, Vitor Rhein. Os sistemas de garantia...: “Consoante se deixará assentado definitivamente ao diante, devemos repisar que o objetivo de se utilizar empresas estatais ou fundo garantidor (desde que se trate de fundo com natureza condominial, tal como o FGP) é o de evitar que eventual processo de execução desemboque no regime de precatórios, preconizado no artigo 100 da Constituição Federal. A razão para tanto é absolutamente simples: sendo as empresas estatais e o fundo garantidor entidades de direito privado, não se lhes aplica o disposto no artigo 100 da Constituição Federal, recaindo eventual execução diretamente sobre o patrimônio da empresa estatal ou do fundo garantidores." 


\section{•• Teoria jurídica do crédito público e operações estruturadas}

Pode-se concluir, portanto, que a estruturação de operações financeiras pelo Estado envolvendo empresas estatais pode ocorrer de diferentes maneiras, com diferentes repercussões fiscais a depender do modelo adotado. Isto ocorre, pois, as empresas estatais não apresentam um único regime jurídico aplicável, o que é também consequência da sua utilização em diferentes contextos pelo Estado, ora como instrumento de intervenção econômica em sentido estrito, ora como instrumento para a prestação de serviços públicos ${ }^{55}$.

\subsubsection{Operações de securitização de créditos públicos}

A conhecida restrição orçamentária dos entes públicos, em face de obrigações políticas fruto da promessa de desenvolvimento brasileiro contida na Constituição Federal de 1988, leva o setor público a buscar, no setor privado, inspiração para aumento da eficiência no gasto público e também no aproveitamento do seu patrimônio.

Sob essa perspectiva, destaca-se a necessidade de se observar não apenas a qualidade do gasto, mas igualmente a disciplina de capital adotada pelos entes públicos, entendida tal disciplina pela estratégia adotada para redução do custo de financiamento das iniciativas do Estado, tanto em termos financeiros, quanto em termos sociais. Neste contexto, soluções próprias do mercado de capitais despontam como nova fronteira de atuação das entidades públicas, visando, ora desviar das limitações impostas pela legislação fiscal, ora maximizar a rentabilidade do patrimônio público, entendida como rentabilidade em sentido amplo, isto é, em sentido que engloba não apenas os resultados financeiros, mas igualmente os retornos sociais da ação estatal.

As operações de securitização são operações estruturadas que se aproximam economicamente das operaçôes de crédito, mas que apresentam características jurídicas que a distinguem de tais operaçóes, trazendo ao jurista o desafio adicional de situar tais operações diante das regras de responsabilidade fiscal vigentes. Daí a importância do seu estudo no âmbito do direito financeiro e da temática do endividamento público, que se mostra urgente diante da prática de tais operações no Brasil, nos últimos anos, especialmente por estados e municípios.

As operaçôes de securitização se inserem no contexto da chamada "desintermediação financeira" 586 , que consiste no recurso direto aos poupadores, por parte dos agentes que buscam captar recursos, sem a necessidade de intermediação por uma instituição

585 SCHIRATO, Vitor Rhein. As empresas estatais..., p. 30: "Nesse cenário de proliferação das empresas estatais, a diversidade das atividades empreendidas por tais entidades e as distinções de seus campos de atuação fizeram com que a identificação de um regime jurídico comum a elas fosse praticamente impossível de ser definido. Enquanto havia empresas estatais atuando em segmentos típicos da iniciativa privada (por exemplo, siderurgia), outras desempenhavam atividades típicas de Estado. Daí adveio a dificuldade que até hoje persiste de se caracterizar um regime jurídico das empresas estatais."

586 PIRES, Daniela Marin. Os fundos de investimento em direitos creditórios (FIDC), p. 29: "A securitização propicia a desintermediação financeira, uma vez que essa operação é realizada no âmbito do mercado de capitais e sem a interferência da instituição financeira, na qualidade de concedente do crédito. Nesse caso, o papel da instituição financeira fica centrado na estruturação da operação, na qualidade de intermediadora/coordenadora da emissão, usualmente conhecida como underwritter." 
financeira ${ }^{587}$. Tal relacionamento ocorre no âmbito do mercado de capitais e apresenta diversas vantagens em relação aos financiamentos bancários. Tais vantagens também se apresentam no caso de instituições públicas, motivo pelo qual a tendência à desintermediação também produz reflexos sobre o direito público e, em especial, sobre o direito financeiro.

Neste contexto, podem-se mencionar como vantagens atreladas às soluçôes de captação de recursos por meio do mercado de capitais as seguintes, vis a vis da utilização de financiamentos bancários convencionais:

a) Possibilidade de se determinar o fluxo de amortizaçôes e de se determinar as formas de remuneração dos títulos: essa vantagem permite ao emissor ajustar o fluxo de pagamentos ao fluxo de caixa do tomador dos recursos, representando uma vantagem em relação a uma operação de crédito padronizada;

b) Acesso direto aos poupadores sem a intermediação de instituição financeira: as operaçôes de crédito dependem da existência de uma instituição financeira que, recorrendo à poupança pública, arca sozinha ou por meio de consórcio, com o risco de crédito do tomador do crédito. Isso reduz a complexidade da operação ao mesmo tempo em que eleva o seu custo financeiro, visto que inclui na equação o spread cobrado pela instituição financeira para tomada deste risco ${ }^{588}$;

c) Existência de mercado secundário: via de regra, as operações de crédito por meio de mútuo bancário não admitem mercado secundário organizado. Isso resulta em um maior risco ao emprestador, visto que, caso as condiçôes econômicas mudem ou se altere a sua percepção de risco, o emprestador não terá alternativas senão aguardar o cumprimento do contrato. Portanto, a existência de mercado secundário reduz a taxa de juros cobrada em relação a um contrato de mútuo feneratício, beneficiando o tomador dos recursos;

d) Maior transparência do mercado de capitais em relação ao mercado bancário: o mercado de capitais é o mercado por meio do qual os tomadores de recursos recorrem diretamente à poupança pública. Essa poupança pública, por sua vez, em sendo um bem jurídico da mais elevada importância, é tutelada por uma série de

7 EIZIRIK, Nelson; GAAL, Ariádna B.; PARENTE, Flávia; HENRIQUES, Marcus de Freitas. Mercado de capitais: regime jurídico, p. 9: "Diversamente do que ocorre no mercado de crédito, no mercado de capitais, a mobilização da poupança é realizada diretamente entre a unidade econômica deficitária a entidade emissora e a unidade econômica superavitária o investidor. Inexiste, no caso, intermediação financeira, pois os recursos fluem diretamente dos adquirentes dos valores mobiliários para as empresas que os emitem."

588 Sobre a lógica do spread como remuneração da instituição financeira, ver EIZIRIK, Nelson; GAAL, Ariádna B.; PARENTE, Flávia; HENRIQUES, Marcus de Freitas. Mercado de capitais: regime jurídico, p. 3-4: "Ao centralizar a oferta e a procura de dinheiro, a instituição financeira empreende uma atividade dupla: ao captar recursos junto aos poupadores, remunerados com juros; ao colocá-los à disposição dos tomadores de recursos cobra destes juros. A remuneração da instituição financeira (o chamado 'spread bancário') consiste na diferença entre a taxa de juros pagos na captação e os juros cobrados nos repasses. Num primeiro momento, ao receber o crédito, o banco figura no pólo passivo da relação comercial, tornando-se devedor do detentor de recursos, daí serem chamadas tais operações de 'passivas' dos bancos; no segundo momento, ao dar o crédito, tornando-se credor do agente econômico deficitário, prática típica operação bancária 'ativa'." 
órgãos, tanto públicos quanto de autorregulação privada, que exigem um elevado nível de transparência, tais como Comissão de Valores Mobiliários - CVM, Associação Brasileira de Entidades dos Mercados Financeiro e de Capitais ANBIMA, sem exclusão dos mecanismos de transparência previstos na Lei Complementar n. 101/2000 e outras.

Estas são algumas das razões que fazem com que diversas entidades, públicas ou não, recorram ao mercado de capitais em lugar de realizar simples operação de mútuo com instituição financeira. Entre os instrumentos disponíveis do mercado de capitais a para tomada de recursos encontram-se as operações de securitização de recebíveis, que vêm se tornando cada vez mais frequentes entre as instituições públicas.

A operação de securitização consiste, de maneira simplificada, no encadeamento da cessão de direitos creditórios a um veículo de investimentos específico - usualmente uma sociedade anônima de propósito específico (SPE) ou um fundo de investimentos em direitos creditórios (FIDC) - com a emissão, por esse veículo, de valores mobiliários ${ }^{59}$. Por meio desse negócio jurídico, a SPE passa a ser titular dos direitos creditórios, expondo os investidores ao risco do fluxo dos recebíveis adquiridos. Ao mesmo tempo, a sociedade originadora-cedente dos recebíveis obtém recursos de forma antecipada, entregues pela SPE ou FIDC como forma de contrapartida da cessão onerosa ${ }^{590}$.

A origem das operações de securitização está ligada à ideia de transferência de risco de ativos de uma instituição para outra, transferindo-o para investidores interessados em auferir rendimentos a partir de tais riscos ${ }^{591}$. Assim, a securitização é um processo, ou seja,

589 ROQUE, Pamela Romeu. Securitização de créditos vencidos e pendentes de pagamento e risco judicial, p. 24: "Desponta, portanto, que a securitização a que nos referimos vale-se de três elementos fundamentais, a saber, i) o veículo de propósito específico; ii) a captação de recursos por este último mediante emissão de valores ou títulos mobiliários; e iii) o contrato de cessão onerosa firmado entre o cedente (na maior parte das vezes no mercado brasileiro, o próprio originador dos créditos) e o veículo de propósito específico."

590 PIRES, Daniela Marin. Os fundos de investimento em direitos creditórios (FIDC), p. 17: "Nesse sentido, uma operação de securitização é aquela em que o originador dos créditos segrega, por meio da cessão de crédito, os direitos de crédito de que é titular a uma sociedade de propósito específico (SPE), denominada securitizadora, que, por sua vez, emitirá valores mobiliários. Esses valores serão adquiridos por investidores e remunerados com o fluxo futuro gerado pelos pagamentos dos referidos direitos de crédito pelos devedores destes.O FIDC é, portanto, uma espécie de operação de securitização. A única diferença entre a securitização [feita por meio de SPE] e os FIDC está, essencialmente, no fato de que, nas operaçôes de securitização, compete à sociedade de propósito específico sociedade anônima adquirir os direitos creditórios e emitir os valores mobiliários lastreados nestes, ao passo que nos FIDCs o fundo, que tem natureza jurídica de condomínio, de acordo com o disposto no art. $3^{\circ}$, inc. I, da Instrução n. 356/2001 embora existam controvérsias na doutrina, conforme será abordado neste trabalho, desempenha o papel da sociedade de propósito específico.” (p. 17)

591 KUGLER, Herbert Morgenstern; NAKAYAMA, Taryta. Do conceito de "despesa de captação", previsto pelo art. $3^{\circ}, \$ 8^{\circ}$, da lei $9.718 / 1998$ para fins de cálculo das contribuições sociais pis e cofins das companhias securitizadoras de créditos imobiliários: "Originalmente, por meio deste modelo, a securitização buscou transferir o risco das instituições financeiras, decorrentes de operações de financiamento, para outros investidores, dispersando, desta forma, o risco associado aos créditos na economial e possibilitando uma oferta mais ampla e barata de crédito.” 
é um conjunto de atos encadeados visando a uma determinada finalidade, por meio do qual se permite a circulação de créditos, transformando, do ponto de vista econômico, ativos de baixa liquidez em ativos de maior liquidez ${ }^{592}$.

Uma das vantagens mais debatidas da securitização em relação aos empréstimos bancários consiste na segregação do risco do investimento, em virtude da segregação dos ativos cedidos que passam a compor lastro específico para a emissão dos valores mobiliários. Assim, da perspectiva do investidor, a operação deixa de carregar o risco de um financiamento à empresa originadora dos créditos, para trazer unicamente o risco dos créditos cedidos, o que favorece a contratação da operação a juros mais favoráveis para o ente originador dos créditos ${ }^{593}$.

Em diversos casos, essa segregação fica contabilmente evidente em função da baixa do ativo cedido do patrimônio da entidade originadora, como consequência da alienação dos créditos sem nenhuma retenção dos riscos envolvidos no seu fluxo de caixa. Como será demonstrado adiante, embora a referida baixa não seja essencial para a descaracterização da operação como operação de crédito, havendo casos em que não se deve desreconhecer o ativo sem que se trate igualmente de operação de crédito, é evidente que a situação fica visualmente mais clara nas hipóteses em que as normas contábeis autorizam a baixa do ativo após a cessão dos créditos ${ }^{594}$.

O veículo necessário à operação de securitização normalmente se apresenta em uma das três estruturas jurídicas seguintes: (i) sociedade de propósito específico; (ii) sociedade securitizadora; e, (iii) fundo de investimentos.

A sociedade de propósito específico é um dos mecanismos mais flexíveis, dado não se submeter a nenhuma regulamentação particular e poder ter por administradores pessoas

592 PIRES, Daniela Marin. Os fundos de investimento em direitos creditórios (FIDC), p. 26: "Faz-se oportuno definir securitização. Trata-se de processo por meio do qual os fluxos financeiros ilíquidos (recebíveis de cartões de crédito, duplicatas, contas a receber) são transformados em títulos líquidos negociáveis no mercado de capitais, propiciando a circulação de riquezas.”

593 PIRES, Daniela Marin. Os fundos de investimento em direitos creditórios (FIDC), pp. 25-6. "A securitização de recebíveis propicia a aproximação de ambas as partes: a empresa, tomadora de recursos, por viabilizar uma alternativa de financiamento de prazo maior e a custos menores, na medida em que, em regra, o risco de crédito ficará relacionado ao fluxo de recebíveis objeto da securitização, possibilitando, por consequência, uma avaliação do risco de crédito dos recebíveis cedidos e não da empresa cedente, o que possibilita uma avaliação melhor do que a da própria cedente.Os direitos creditórios de que a empresa cedente é titular, os quais pretende securitizar, podem obter uma boa avaliação de crédito e, por essa razão, a empresa cedente se financiará a um custo menor, comparado ao custo de financiamento, representado por uma operação de empréstimo perante uma instituição financeira, em que a avaliação de crédito é realizada sobre a empresa cedente."

594 PIRES, Daniela Marin. Os fundos de investimento em direitos creditórios (FIDC), p. 30: “Um dos grandes benefícios indiretos contábeis da securitização, de acordo com Schwarcz, é o de que a securitização consiste em um meio de captação off balance, haja vista que a securitização é contabilmente considerada uma venda de ativos e não um financiamento, e, por conseguinte, o originador dos recebíveis securitizados não contabiliza a operação como um passivo no seu balanço. Por consequência, essa operação propicia a captação de recursos, sem que haja o aumento do percentual entre o patrimônio e a dívida leverage or debt-to-equity ratio das demonstrações financeiras do originador." 


\section{•• Teoria jurídica do crédito público e operações estruturadas}

físicas, o que não ocorre, por exemplo, no caso dos fundos de investimento. Contudo, é preciso lembrar que, se a intenção final do ente público com a operação é a colocação de valores mobiliários para livre negociação no mercado, então, será necessário valer-se de sociedade anônima, em conformidade com o que prevê o artigo $1^{\circ}, \$ 2^{\circ}$, da Instrução CVM n. 480/2009595.

Entre os fundos de investimento utilizados para a securitização, destacam-se os fundos de investimentos em direitos creditórios (FIDCs), que tiveram a sua constituição e funcionamento autorizados pela Resolução n. 2.907/2001, do Conselho Monetário Nacional, vindo a ser disciplinados em maiores detalhes pela Instrução n. 356/2001, da Comissão de Valores Mobiliários. O FIDC, assim como os demais fundos de investimento, é um condomínio, podendo ser do tipo aberto ou fechado, cujo objetivo é o investimento preponderante em direitos creditórios ${ }^{596}$.

O FIDC é uma estrutura mais complexa que a SPE, visto depender da coordenação de diversos agentes e prestadores de serviços, além de submeter-se à regulamentação própria da Comissão de Valores Mobiliários. Para existência de um fundo desta natureza, por exemplo, é necessária a presença de um administrador, dada a ausência de personalidade jurídica do fundo; de um custodiante para os documentos que dão lastro aos créditos; de uma agência de classificação de risco, que à vista do regulamento do fundo e das características do crédito dará a sua opiniāo acerca do seu risco; de auditores independentes; de um master servicer, para a coordenação e execução das ações de cobrança; além de consultores especializados ${ }^{597}$.

595 ROQUE, Pamela Romeu. Op. cit., p. 36: “Ademais, a SPE não é, em si, um tipo societário, de modo que há flexibilidade de sua constituição quanto à adoção de sua forma. V. P. ZICA aponta para o fato de que só não podem ser sociedades em nome coletivo disciplinadas nos arts. 1.039 a 1.044 do Código Civil. No entanto, com o propósito de negociar os valores mobiliários emitidos pela SPE no mercado de valores mobiliários, é necessário observar que elas costumam assumir a forma de sociedade anônima de capital aberto, em conformidade com o art. $4^{\circ}$ da Lei n. 6.404/76 e art. $1^{\circ}$ da Instrução CVM n. 480, de 07 de dezembro de 2009. Entretanto, ainda com esse objetivo, dependendo do valor mobiliário a ser emitido, é possível estabelecê-la também sob a forma de sociedade anônima de capital fechado ou sociedade limitada, se os esforços de distribuição forem restritos, no âmbito da Instrução CVM n. 476/2009.”

596 ROQUE, Pamela Romeu. Op. cit., p. 41: "O FIDC é uma comunhão de recursos constituída sob a forma de condomínio aberto - em que os condôminos podem solicitar resgate de cotas, em conformidade com o disposto no seu regulamento - ou fechado - em que as cotas somente podem ser resgatadas ao término do prazo de duração do fundo ou em virtude de sua liquidação, admitindo-se, ainda, a sua amortização por disposição do regulamento ou decisão da assembleia geral de cotistas -, que tem como objetivo de investimento a aquisição preponderante de direitos creditórios, sendo autorizado também o investimento em ativos financeiros expressamente previstos na regulamentação. O seu patrimônio é representado por cotas, sendo que cada uma delas, como regra geral, outorga a seu titular o direito a um voto nas assembleias gerais dos cotistas. Esse direito de voto pode ser limitado ou diferenciado para classes distintas de cotas, desde que expressamente previsto no regulamento."

597 ROQUE, Pamela Romeu. Idem, ibidem.: "Ressalta-se, ainda, que a estrutura operacional de um FIDC depende da atuação de diversos prestadores de serviços, aos quais é atribuída uma série de regras e obrigações para a sua boa estruturação e funcionamento. Dentre eles, citamos: administrador, gestor, custodiante, agência de classificação de risco, auditor independente, estruturador, master servicer e consultores especializados. A esse respeito, comentamos que recentemente, em 06 de fevereiro de 2013, a CVM editou a Instrução CVM n. 531/13, que alterou algumas disposições da Instrução CVM n. 356/01, com 
Segundo as regras da CVM, os fundos de investimento em direitos creditórios podem ser padronizados ou não padronizados, sendo os últimos aqueles que permitam em sua política de investimentos a aplicação em créditos de menor probabilidade de solvência, dentre os quais: (i) créditos vencidos e inadimplentes; (ii) créditos decorrentes de receitas públicas; (iii) créditos sub-judice; (iv) créditos cuja validade da cessão seja fator de relevante risco; (v) créditos que tenham sua origem em processo de recuperação judicial ou extrajudicial; (vi) créditos de existência futura e montante desconhecido. Sobre os FIDCs não padronizados, é importante mencionar que não são investimento a ser adquirido por pequenos investidores, podendo ser negociadas as suas cotas em mercado secundário apenas entre investidores profissionais, o que contribui para a sua não aquisição por pequenos investidores ${ }^{598}$.

Em alguns casos específicos, quando o fluxo a ser cedido não for conhecido com segurança, a utilização de critérios de subordinação pode auxiliar na adequação dos fluxos de ativos e passivos na operação, evitando descasamentos, em virtude da maior flexibilidade das debêntures, ou cotas subordinadas, conforme o caso ${ }^{599}$. Nestes casos, é possível que sejam mantidos na contabilidade da entidade cedente os créditos, unicamente para atendimento das normas e padrôes de contabilidade internacionalmente aceitos, o que não interfere na natureza jurídica da operação.

Como afirmado, tanto no caso da securitização por meio de sociedades securitizadoras quanto por meio de FIDCs é comum que o cedente amplie a segurança do investimento para o adquirente dos valores mobiliários emitidos ao final da operação, por meio da subscrição de valores mobiliários (debêntures ou cotas de FIDCs) subordinados. Neste caso, torna-se possível conferir ao titular dos valores mobiliários seniores preferência no recebimento dos rendimentos, resgatando-se os valores subscritos pela originadora dos créditos cedidos apenas após o pagamento dos investidores ${ }^{600}$. O resgate neste caso pode ocorrer em dinheiro, mas também em direitos creditórios, o que também favorece a regularidade do fluxo de caixa do veículo de securitização adotado ${ }^{601}$.

o objetivo de tornar mais claras e definidas as responsabilidades e atribuições de todos os prestadores de serviços contratados para os FIDCs, bem como mitigar estruturas que pudessem ensejar a ocorrência de conflitos de interesse."

598 Cf. Instrução CVM n. 444/2008.

599 SOUTO, Marcos Juruena Villela; ROCHA, Henrique Bastos. Securitização de recebíveis de royalties do petróleo: "A utilização do mecanismo de emissão de debêntures subquirografárias e seu uso como parcela do pagamento à entidade pela cessão dos recebíveis têm como finalidade ajustar o valor a ser pago à entidade federada ao montante efetivamente recebido a título de "royalties do petróleo e participação especial", já que não se pode antever com precisão os valores recebíveis, por serem dependentes do nível de atividade de extração de petróleo."

600 MARTINS, Eliseu; GELBCKE, Ernesto Rubens; SANTOS, Ariovaldo dos; IUDÍCIBUS, Sérgio. $M a-$ nual de contabilidade societária: aplicável a todas as sociedades - de acordo com as normas internacionais e do CPC, p. 130: "As cotas dos fundos devem ser escriturais e mantidas em conta de depósito em nome de seus titulares. As cotas podem ser do tipo sênior ou subordinada. As cotas do tipo sênior têm preferência no recebimento da amortização e resgate. As cotas do tipo subordinada têm o resgate e amortização subordinados ao das cotas seniores."

601 SALOMÃO NETO, Eduardo. Direito bancário, p. 523: "As cotas dos fundos de recebíveis podem ser de classe sênior ou subordinada. O caráter distintivo das cotas subordinadas é só receberem rendimentos 


\section{•• Teoria jurídica do crédito público e operações estruturadas}

Na hipótese acima destacada, contudo, o chamado "reforço de crédito", que normalmente é realizado com a finalidade de redução do risco da operação para os investidores, obtendo assim melhor rating na emissão dos valores mobiliários a serem subscritos, torna a distinção da securitização em relação às operações de crédito mais complexa, demandando do operador do direito um maior cuidado na análise dos instrumentos contratuais que regem a operação.

Créditos são considerados bens móveis para fins legais ${ }^{602}$, assim, a sua aquisição por sociedade securitizadora possui caráter de cessão de créditos e não de mútuo ${ }^{603}$. Se assim não fosse, as sociedades securitizadoras e também as factorings teriam de ser consideradas instituições financeiras, na forma do artigo 17 da Lei n. 4.595/64, sendo autorizadas a funcionar pelo Banco Central do Brasil (BCB $)^{604}$. Não é isso, porém, que ocorre, tendo em vista a aceitação, no momento atual, pelo $\mathrm{BCB}$ da atividade não privativa de instituição financeira desempenhada pelas securitizadoras e pelas factorings ${ }^{605}$.

O desconto bancário também é modalidade de cessão de crédito e não de mútuo. Contudo, no desconto bancário há a assunção pelo cedente da responsabilidade pela solvência do crédito, isto é, ocorre cessão pro solvendo à instituição bancária, na forma do artigo 296 do Código Civil ${ }^{606}$. Neste caso, portanto, não há mútuo, mas há uma operação

quando e se paga integralmente a remuneração estipulada para as cotas seniores, bem como a possibilidade de serem integralizadas e resgatadas pela transferência de direitos creditórios ainda não realizados. Em virtude disso, são usadas pelas instituiçôes financeiras que promovem o fundo para dar garantias de liquidez para os demais cotistas. Ao adquirirem cotas subordinadas, além da cessão onerosa descrita no parágrafo anterior, cedem ao fundo pacote adicional de créditos através da integralização com eles de cotas subordinadas. Se os créditos cedidos apresentarem níveis altos de inadimplemento, o excesso aumenta a segurança dos investidores ordinários (os cotistas seniores) de que receberão o valor de resgate de suas cotas.”

602 Código Civil de 2002, artigo 83, III.

603 SALOMÃO NETO, Eduardo. Direito bancário, p. 511: "O que a sociedade que tem por objeto o factoring faz é adquirir direitos de crédito preexistentes, os quais se qualificam como coisas para efeitos civis e são equiparados aos móveis pelo artigo 83, inciso III, do Código Civil. O substrato jurídico do factoring é de fato uma cessão de crédito, e não um mútuo."

604 Isto, pois a jurisprudência tem se firmado no sentido de que o artigo 17 da Lei n. 4.595/64 deve ser lido de forma restrita, apenas se compreendendo no conceito de instituição financeira aquela que aplique os recursos captados em operaçôes ativas que se compreendam na ideia de operação de crédito ou operação financeira. Ver também EIZIRIK, Nelson; GAAL, Ariádna B.; PARENTE, Flávia; HENRIQUES, Marcus de Freitas. Mercado de capitais: regime jurídico, p. 6: "Assim, de acordo com a melhor interpretação do art. 17 da Lei n. 4.595/1964, para caracterizar-se a atividade privativa da instituição financeira exige-se a presença cumulativa dos seguintes elementos: a captação de recursos financeiros em nome próprio; seguida do repasse mediante operação de mútuo financeiro; com o intuito de auferir lucro; realizada tal modalidade de operação em caráter habitual.”

605 Ver, por exemplo, Resolução CMN n. 2.686/97 e a Circular BCB n. 2.715/96.

606 SALOMÃO NETO, Eduardo. Op. cit., p. 513. "Finalmente, há que se considerar que a cessão de crédito é disciplinada nos artigos 286 a 298 do Código Civil, como negócio potencialmente oneroso, isto é, feito na expectativa da contraprestação, a qual poderia ser constituída pelos recursos repassados através do desconto. Ainda mais, a responsabilidade do cedente pelo pagamento dos créditos no vencimento, que caracteriza o desconto é regra de livre estipulação nas cessões de créditos, segundo o artigo 296 do Código Civil, ainda que não se considere parte do negócio se dele não constar expressamente. Isso mostra que o desconto é figura negocial que se encaixa perfeitamente na disciplina da cessão de crédito.” 
de crédito, por se tratar de recebimento antecipado pela venda a termo de bens e serviços (no caso de cessão pro solvendo de créditos comerciais) ou por se tratar de operação assemelhada a um recebimento antecipado pela venda a termo de bens e serviços (no caso da cessão pro solvendo de créditos de outra natureza) ${ }^{607}$. Em ambos os casos, porém, a operação de crédito apenas existe no lugar de uma simples alienação, na hipótese de se manter no cedente a responsabilidade pela quitação do crédito cedido, seja diretamente pela solvência do devedor, seja pela recompra do crédito. Isto, pois apenas nessa hipótese haverá o caractere temporariedade, que é elementar nas operações de crédito ${ }^{608}$.

Deve-se, portanto, atentar para o fato de que não é correto identificar qualquer antecipação de receita, do ponto de vista econômico, como uma operação de crédito. Há inúmeras hipóteses possíveis de antecipação de receitas que em nada se aproximam de operações de crédito e que evidenciam o equívoco de tal confusão ${ }^{609}$. Poder-se-ia, por exemplo, verificar que a venda de um imóvel público que gera renda mensal de aluguel é uma forma econômica de antecipar as receitas deste bem ${ }^{610}$. Contudo, não há qualquer menção na legislação à ideia de que a venda de unidades geradoras de renda, como o imóvel mencionado, deva atender aos critérios e condições fixados no artigo 32 da LRF e nas resoluções do Senado Federal relativas ao endividamento público.

A operação de crédito, na ordem jurídica brasileira, não remete necessariamente a uma operação de mútuo convencional, podendo tomar diversas formas contratuais ${ }^{611}$. Contudo, está no centro do conceito a ideia de utilização temporária de recursos de terceiros, para posterior devolução. $\mathrm{O}$ simples fato de o conceito de operação de crédito permitir a existência de múltiplas formas contratuais não implica dizer que qualquer fenômeno que envolva a entrega de recursos no presente contra um direito futuro seja uma operação de crédito.

Nesta linha de argumentação, Heleno Taveira Torres menciona a existência necessária de três elementos - (i) confiança, (ii) capital e (iii) tempo - para se poder falar em

${ }^{607} \mathrm{Na}$ forma do artigo 29, III da LRF.

${ }^{608}$ Geraldo Ataliba ressalta a importância do aspecto temporal, isto é, da precariedade do ingresso dos recursos, como elemento essencial para configuração das operações de crédito. Uma das características essenciais das obrigaçōes é a sua transitoriedade e por meio desta característica se pode distinguir, por exemplo, a obrigação da plena propriedade, que tende a ser perene: NOGUEIRA, José Geraldo de Ataliba. Empréstimos públicos e seu regime jurídico, pp. 2-3.

609 SOUTO, Marcos Juruena Villela; ROCHA, Henrique Bastos. Securitização de recebíveis de royalties do petróleo: "A operação de alienação de crédito que se pretende empreender, ainda que represente um 'recebimento antecipado de receita', não se adapta rigorosamente no conceito de 'venda de bens ou serviços.'”

610 Do ponto de vista econômico inclusive, o valor justo do imóvel poderia ser calculado pelo valor presente do fluxo de caixa esperado dos alugueres.

611 TORRES, Heleno Taveira. Direito Constitucional Financeiro: Teoria da Constituição Financeira, p. 447: "Na teoria geral das obrigaçôes, crédito equivale ao direito subjetivo do sujeito ativo, no âmbito de uma relação obrigacional. No presente contexto, todavia, operações de crédito vinculam-se ao negócio jurídico de 'crédito', logo, à noção de 'empréstimo'. Na esteira da lição de Geraldo Ataliba, conclui-se que operação de crédito abrange quaisquer operaçôes que envolvam a utilização de recursos de outrem por um período de tempo, de modo a extrapolarem-se as noções de mútuo e de comodato. Logo, as operaçôes de crédito podem se revestir de variadas formas e diversos negócios jurídicos.” 
operação de crédito $^{612}$. Contudo, tais elementos ainda não são suficientes, posto que não diferenciariam, em tese, uma operação de crédito de um investimento em um contrato de concessão administrada ou mesmo patrocinada em uma parceria público-privada. A operação de crédito, enquanto modalidade de empréstimo, tem na sua essência um compromisso de devolução da coisa recebida, ou de coisa de mesma espécie e quantidade ${ }^{613}$.

Para melhor entendimento da questão que se coloca, é benéfica a análise do Pronunciamento n. $38^{614}$, do Comitê de Pronunciamentos Contábeis, que até $1^{\text {o }}$ de janeiro de 2018 era de observância obrigatória por todas as instituições públicas e privadas, no exercício da função contábil, e que tratava do reconhecimento e mensuração de instrumentos financeiros. Nos itens 17 a 22 do referido Pronunciamento, verifica-se que a baixa contábil de um instrumento financeiro apenas deve ocorrer em caso de transferência substancial de todos os riscos e benefícios da propriedade do ativo financeiro, sendo que tal transferência deve ser avaliada em vista da variação do fluxo de caixa esperado da entidade antes e depois da transferência ${ }^{615}$.

612 TORRES, Heleno Taveira. Idem, ibidem. "Destarte, não obstante a multiplicidade de negócios caracterizadores de operaçōes de crédito, à luz da LRF, sua configuração queda-se balizada pelas qualificações adotadas expressamente, bem como pelas equiparaçōes que a lei complementar admite. Para aquelas sob a cláusula de equiparação: "outras operaçōes assemelhadas", porém, requer-se, necessariamente, alguma equivalência com as tipologias possíveis e que se possa determinar a presença de três elementos, quais sejam: (i) confiança, (ii) capital e (iii) tempo, tendo em vista que o "crédito" pressupõe justamente a "troca de um bem ou valor no presente por uma promessa de riqueza futura que, aliás, será a responsável pelo reembolso do que foi emprestado e pelo pagamento dos juros ou outros benefícios oferecidos aos prestamistas". Portanto, pode-se concluir que o art. 29, III, da LRF delimita-se pelo campo material da noção de "operações de crédito", defesa sua extensão para alcançar evemo que não possa ser reconduzido à noção de operações de crédito." A mesma opinião aparece em ASSONI FILHO, Sérgio. Crédito público e responsabilidade fiscal, p. 18: "Ao lado dos elementos confiança e existência de capital, para que se efetive uma operação de cunho creditício, necessariamente estará presente o elemento tempo, uma vez que o crédito implica a troca de um bem ou valor no presente por uma promessa de riqueza futura que, aliás, será a responsável pelo reembolso do que foi emprestado e pelo pagamento dos juros ou outros benefícios oferecidos aos prestamistas."

613 SOUTO, Marcos Juruena Villela; ROCHA, Henrique Bastos. Securitização de recebíveis de royalties do petróleo: "Em todo caso, exige para sua existência a entrega de uma quantidade e o compromisso de restituição, sendo indiferente que entrega e compromisso se realizem de modo voluntário ou forçoso."

${ }^{614}$ Correspondente ao IAS n. 39 (Financial Instruments: Recognition and Measurement) do International Accounting Standards Board (IASB).

615 Pronunciamento CPC n. 38, item 21: "A transferência de riscos e benefícios (ver o item 20) é avaliada por comparação da exposição da entidade, antes e depois da transferência, com a variabilidade das quantias e a distribuição dos fluxos de caixa líquidos do ativo transferido. A entidade reteve substancialmente todos os riscos e vantagens da propriedade do ativo financeiro se a sua exposição à variabilidade do valor presente dos fluxos de caixa líquidos futuros resultantes do ativo financeiro não se alterar significativamente em resultado da transferência (por exemplo, porque a entidade vendeu um ativo financeiro sujeito a um acordo de recompra a um preço fixo ou ao preço de venda acrescido do retorno do mutuante). A entidade transferiu substancialmente todos os riscos e benefícios da propriedade de ativo financeiro se a sua exposição a essa variabilidade já não for significativa em relação à variabilidade total do valor presente dos fluxos de caixa líquidos futuros associados ao ativo financeiro (por exemplo, porque a entidade vendeu um ativo financeiro sujeito apenas a uma opção de recompra pelo seu valor justo no momento da recompra ou transferiu uma parte totalmente proporcional dos fluxos de caixa resultantes de ativo financeiro maior em acordo, tal como a sub participação em empréstimo que satisfaça as condições do item 19).” 
O mencionado Pronunciamento n. 38 foi revogado pelo Pronunciamento n. 48, de 4 de novembro de 2016, com efeitos a partir de $1^{\circ}$ de janeiro de 2018 , sem, contudo, alteraçōes quanto à análise aqui desenvolvida e suas conclusōes ${ }^{616}$.

No caso de operações que envolvam a subscrição de debêntures ou cotas subordinadas, entende-se que haveria retenção substancial dos riscos e que, portanto, não seria adequada a baixa dos créditos transferidos no ativo da entidade originadora ${ }^{617}$. Isso, porém, nem sempre será verdadeiro, visto que a cessão pode envolver transferência substancial do risco mesmo em face da existência de ordem de preferência de pagamento ${ }^{618}$. Tratar-se-á, portanto, de uma questão a ser avaliada a cada caso, em face do tamanho das debêntures/cotas subordinadas em relação à obrigação de pagamento às debêntures/cotas seniores. Se, em função das variáveis concretas, for altamente improvável a ausência de pagamento das debêntures/cotas seniores, recaindo todo o risco sobre o detentor das debêntures/cotas subordinadas, então, deve-se inequivocamente manter o registro do instrumento financeiro no ativo da entidade cedente.

Importa, entretanto, ressaltar que, o fato de se manter o registro do instrumento no ativo em função de retenção de parcela substancial do risco não implica dizer que há garantia de adimplemento ao investidor titular das debêntures/cotas seniores. Implica apenas dizer que uma parte do risco permanece com o originador dos créditos, na forma da variância do fluxo de caixa decorrente da titularidade das debêntures/cotas subordinadas e que, por esta razão, o registro adequado da situação patrimonial do ente cedente depende da manutenção do registro do ativo e também de eventual provisionamento em função de possíveis perdas na cobrança dos créditos. Não se pode, portanto, pretender extrair dos pronunciamentos CPC n. 38 e n. 48 mais do que eles efetivamente dizem, no que se refere à transferência do risco.

Por outro lado, os itens 18 e 19 do mesmo Pronunciamento CPC n. 38 são bastante relevantes na discussão acerca da existência ou não de operação assemelhada a operação de crédito na cessão de créditos, uma vez que reportam aos requisitos para se avaliar se a transferência do ativo financeiro efetivamente ocorre em caráter definitivo ou não. Esses dois itens (18 e 19) lidos em conjunto aos itens 20 e 21 deixam clara a possibilidade de haver transferência definitiva do ativo financeiro, sem que haja transferência substancial dos riscos e benefícios do instrumento. Nesse caso, a transferência definitiva do ativo sem responsabilidade do cedente pelo adimplemento do crédito deixa claro não se tratar de

616 Ver Seção 3.2 "Desreconhecimento de ativo financeiro" do referido Pronunciamento n. 48.

617 SALOMÃO NETO, Eduardo. Op. cit., p. 523-4: “(...) a cessão de créditos em contrapartida à aquisição dessas cotas deve ser classificada para fins contábeis como operação com retenção substancial de riscos e benefícios, o que significa que os créditos cedidos devem continuar registrados em sua integralidade no ativo da instituição financeira cedente, com seus respectivos provisionamentos."

${ }^{618}$ MARTINS, Eliseu; GELBCKE, Ernesto Rubens; SANTOS, Ariovaldo dos; IUDÍCIBUS, Sérgio. Manual de contabilidade societária: aplicável a todas as sociedades - de acordo com as normas internacionais e do CPC, p. 125: "Os casos onde não é possível avaliar se houve retenção substancial dos riscos e benefícios normalmente envolvem a emissão de alguma garantia pela entidade vendedora. Quando a garantia protege somente uma parcela dos riscos e benefícios, isso pode significar que não houve retenção nem transferência substancial dos riscos e benefícios relacionados à propriedade do ativo financeiro transferido." 
operação de crédito ${ }^{619}$; em paralelo, a retenção de parcela substancial do risco pelo cedente demanda a manutençáo do registro do ativo cedido no balanço da entidade cedente. Para o Pronunciamento n. 48, as referências são ao seu item 3.2, que trata do tema do "desreconhecimento de ativo financeiro" 620.

O mesmo se pode extrair da Instrução CVM n. 489, de 14 de janeiro de 2011, que visa a estabelecer regras para contabilização em fundos de direitos creditórios. Do artigo $3^{\circ}$ ao $7^{\circ}$ da mencionada Instrução se estabelece claramente a ideia de que a cessão de direitos creditórios para securitização que envolva a subscrição de cotas subordinadas pelo cedente não consiste em cessão com transferência definitiva de riscos e benefícios e, portanto, deve seguir a regra que impõe o não desconhecimento do ativo financeiro no patrimônio do cedente e impóe o registro do passivo respectivo no mesmo ente ${ }^{621}$. Contudo, o artigo $7^{\circ}, \$ 2^{\circ}$ reconhece a existência de situaçôes que implicam a transferência parcial de risco ao fundo, exigindo o mesmo tratamento contábil ${ }^{622}$.

Reside nesse ponto diferença fundamental a ser demonstrada entre a cessão de direitos creditórios com retenção de parcela dos riscos e benefícios e as operações de crédito.

619 Utilizando esse argumento como fundamento para concluir pela não aplicação das regras relativas às operações de crédito no caso de securitização de receitas de participação em royalties do petróleo, SOUTO, Marcos Juruena Villela; ROCHA, Henrique Bastos. Securitização de recebíveis de royalties do petróleo. "De notar que, no formato proposto, não há qualquer compromisso financeiro assumido pelo Erário, já que a adquirente será remunerada pelos recursos obtidos junto à União Federal. O Poder Público não terá qualquer obrigação, nem mesmo se não se consumar a arrecadação de royalties (embora o risco seja contemplado no valor a ser pago pelos direitos alienados).”

620 Este Pronunciamento foi aprovado pela CVM pela Deliberação n. 763/2016, tornando-o obrigatório para as companhias abertas.

621 FAVERO JUNIOR, Osvaldo Zanetti. Securitização de ativos e transferência de risco: evidências do mercado de capitais brasileiro, pp. 57-8: "Como se vê, a ICVM n. 489 (2011) é bem mais incisiva com relação às operações que devem ser classificadas como sem aquisição substancial dos riscos e benefícios, citando, inclusive a possibilidade de existência de garantia implícita. Está muito claro, por esses comandos que o interesse retido pelo cedente através de cotas subordinadas é um indicador de retenção substancial de riscos (quando igual ou superior às perdas esperadas), sendo pela norma, inclusive, fator de não exposição do fundo à variabilidade no valor presente do fluxo de caixa futuro relacionado ao ativo financeiro."

622 "Art. 70 O registro contábil das operações em que a aquisição substancial dos riscos e benefícios sobre os direitos creditórios não possa ser definida objetivamente deve observar os seguintes procedimentos: I registro no ativo, em conta representativa de direitos creditórios com aquisição substancial de riscos e benefícios, em conformidade com a natureza da operação original, da proporção correspondente aos riscos e benefícios dos direitos creditórios transferidos para o fundo; e II - registro no ativo, em conta representativa de direitos creditórios sem aquisição substancial de riscos e benefícios, da proporção correspondente aos riscos e benefícios dos direitos creditórios não transferidos para o fundo.

(...)

$\$ 2^{\circ}$ Para o fim do disposto no caput deste artigo, subentende-se que a garantia prestada pelo cedente ou parte relacionada, por qualquer forma, inclusive com aquisição de cotas subordinadas do fundo ou assunção de obrigação não formalizada, seja de valor considerado suficiente para a retenção de alguns riscos e benefícios de propriedade do direito creditório, mas não substancialmente todos, de forma que o fundo também passe a adquirir outros riscos e benefícios de propriedade do direito creditório objeto da operação." 
Nas operações de crédito, a retenção do risco é inteiramente do cedente, cabendo ao emprestador dos recursos suportar, em última instância, o risco de inadimplência do próprio tomador de recursos. Esse é o caso da operação de desconto bancário, apresentada acima. Por outro lado, no caso da cessão de direitos creditórios com aporte de debêntures ou cotas subordinadas, em regra, o risco do cessionário não é o risco de inadimplência do cedente - que não tem corresponsabilidade pela solvência dos créditos -, mas sim o risco de inadimplência dos devedores dos créditos cedidos. Isso é verdade pois não se pode confundir o chamado "reforço de crédito" com garantia ao adimplemento ${ }^{623}$.

A Resolução n. 3.533, do Conselho Monetário Nacional, de 31 de janeiro de 2008, que trata das regras relativas à classificação, registro contábil e divulgação de operações de venda ou de transferência de ativos financeiros, por sua vez, traz no seu artigo $2^{\circ}, \$ 2^{\circ}$, $\mathrm{V}^{624}$, e no seu artigo $3^{\circ}, \S 2^{\mathrm{o}^{625}}$, regra que, embora se aplique apenas às instituições financeiras, serve de referência para análise. Neste dispositivo, se estabelece a presunção de não transferência dos riscos e benefícios no caso de subscrição de cotas quando o valor da garantia prestada, por qualquer forma, para compensação de perdas de crédito, for superior à perda provável ou ainda quando o valor das cotas subordinadas de FIDC adquiridas for superior à perda provável.

Torna-se, nesse contexto, necessário aclarar que a presunção de transferência sem retenção dos riscos tratada nesta Resolução não é absoluta, uma vez que o artigo $3^{\circ}$ traz expressamente responsabilidade da instituição financeira cedente avaliar se houve ou não tal transferência de riscos e benefícios, com base em específica metodologia, preferencial-

${ }^{623}$ É claro que se o reforço de crédito for tal que demonstre se tratar de evidente fraude por meio da qual a inadimplência tenha que chegar a 99,9\% dos créditos cedidos, por exemplo, antes de haver risco de não recebimento pelos debenturistas/cotistas seniores, se estará diante de operação de crédito. Esse não é, porém, o caso da grande maioria das operações de securitização, especialmente, as realizadas por entidades do setor público. Uma vez que não há regra objetiva para o caso, é válida a utilização do postulado da razoabilidade na aplicação das normas em apreço e na identificação da natureza correta da operação. Sobre a razoabilidade, ver AVILA, Humberto. Teoria dos princípios: da definição à aplicação dos princípios jurídicos, pp. 176-7.

${ }_{624}$ "Art. $2^{\circ}$ As instituiçōes referidas no art. $1^{\circ}$ devem classificar a venda ou a transferência de ativos financeiros, para fins de registro contábil, nas seguintes categorias: (...) $\$ 2^{\circ} \mathrm{Na}$ categoria operaçōes com retenção substancial dos riscos e benefícios devem ser classificadas as operações em que o vendedor ou cedente retém substancialmente todos os riscos e benefícios de propriedade do ativo financeiro objeto da operação, tais como: (...) V - venda de recebíveis para os quais o vendedor ou o cedente garanta por qualquer forma compensar o comprador ou o cessionário pelas perdas de crédito que venham a ocorrer, ou cuja venda tenha ocorrido em conjunto com a aquisição de cotas subordinadas do Fundo de Investimento em Direitos Creditórios (FIDC) comprador, observado o disposto no art. 3o."

${ }^{625}$ "Art. $3^{\circ} \mathrm{A}$ avaliação quanto à transferência ou retenção dos riscos e benefícios de propriedade dos ativos financeiros é de responsabilidade da instituição e deve ser efetuada com base em critérios consistentes e passíveis de verificação, utilizando-se como metodologia, preferencialmente, a comparação da exposição da instituição, antes e depois da venda ou da transferência, relativamente à variação no valor presente do fluxo de caixa esperado associado ao ativo financeiro descontado pela taxa de juros de mercado apropriada, observado que: (...) $\$ 2^{\circ}$ Presume-se que os riscos e benefícios do ativo financeiro foram retidos pelo vendedor ou cedente quando o valor da garantia prestada, por qualquer forma, para compensação de perdas de crédito, for superior à perda provável ou ainda quando o valor das cotas subordinadas de FIDC adquiridas for superior à perda provável." 


\section{•• Teoria jurídica do crédito público e operações estruturadas}

mente, a partir da "comparação da exposição da instituição, antes e depois da venda ou da transferência, relativamente à variação no valor presente do fluxo de caixa esperado associado ao ativo financeiro descontado pela taxa de juros de mercado apropriada”. Assim, o mencionado $\$ 2^{\circ}$ do artigo $3^{\circ}$ é mera diretriz para o caso de não ser possível a demonstração por meio da citada metodologia da transferência ou não dos riscos e benefícios ${ }^{626}$.

Ademais, torna-se, mais uma vez, conveniente afirmar que a presunção de não ter havido transferência substancial dos riscos e benefícios não implica, por óbvio, certeza de haver operação de crédito. Ora, se a presunção é apenas relativa, é possível a demonstração, fática ou estocástica, de que houve a transferência de riscos relevantes, expondo-se o cessionário, ainda que de forma parcial, à variação do fluxo de caixa dos créditos.

Osvaldo Zanetti Favero Junior, em dissertação de mestrado defendida junto à Faculdade de Economia, Administração e Contabilidade da Universidade de São Paulo, sob orientação do professor Eliseu Martins, critica o método de contabilização da securitização proposto na mencionada Instrução CVM n. 489/11, justamente sob o argumento de que o método conduz à uma avaliação equivocada do tamanho da exposição do ente cedente ao risco de fluxo de caixa, fazendo parecer ao avaliador do balanço patrimonial haver uma operação de empréstimo onde verdadeiramente não há tal operaçãa ${ }^{627}$.

Neste ponto é importante fazer a distinção das operações nas quais há integralização inicial de debêntures/cotas subordinadas, limitando-se a exposição do ente cedente ao fluxo de caixa dos créditos, daqueles em que, além da integralização inicial, há o compromisso de aportes adicionais em caso de aumento da inadimplência dos créditos. Neste segundo caso, que, para os FIDCs, se identifica com a hipótese do artigo 30, III, da Instrução CVM n. 489/11 ${ }^{628}$, fica clara a garantia integral de solvência dos créditos por

${ }^{626}$ FAVERO JUNIOR, Osvaldo Zanetti. Securitização de ativos e transferência de risco: evidências do mercado de capitais brasileiro, p. 60: "O que se pretende destacar é que considerando-se a existência de um nível de subordinação acima do valor das perdas esperadas da carteira transferida em uma estrutura de securitização (por exemplo, em um fundo) e não havendo nenhum outro mecanismo de retenção de risco pelo cedente que o exponha a riscos além do nível registrado, esse critério conduz ao registro de um critério que não reflete as condições econômicas da transação."

${ }^{627}$ FAVERO JUNIOR, Osvaldo Zanetti. Securitização de ativos e transferência de risco: evidências do mercado de capitais brasileiro, p. 62: "Verifica-se, portanto, que a definição de retenção de risco pelo nível de subordinação pode trazer um retrato contábil não consistente com a estrutura econômica da transação. Mesmo que se considere um nível de subordinação inferior às perdas esperadas, não se pode dizer que há diferença entre esta e a situação que absorva, por exemplo, a totalidade do risco dos ativos, sendo que a exposição em ambas as situações é com base em um ativo, que, no limite, seria igual a zero. Não se está inferindo, contudo, que não haja retenção do risco pelo cedente com a situação de retenção de cotas subordinadas. O que se quer mostrar é que a situação desta retenção não induz, per se, a existência de um passivo, sendo que este valor registrado nunca será exigido (não é uma obrigação presente). Concorda-se que há uma retenção de risco através de cotas subordinadas, podendo-se até ser uma retenção substancial dos riscos de acordo com o nível, mas não se pode vincular essa retenção à manutenção dos ativos transferidos no cedente e muito menos ao reconhecimento de um passivo, não havendo adesão deste retrato à estrutura econômica subjacente à transação."

628 "Art. $3^{\circ}(\ldots) \$ 2^{\circ}$ No grupo definido no inciso II do caput devem ser classificadas as operações em que o fundo não adquire substancialmente todos os riscos e benefícios de propriedade do direito creditório objeto da operação e que, como consequência, não ensejam a baixa do direito creditório nos registros 
Operações estruturadas: conceito, oportunidades e impactos nas finanças públicas

parte do cedente e, por consequência, se tratar de uma operação de crédito. O mesmo se pode dizer no caso de ajuste para substituição de créditos inadimplidos por outros créditos, na forma do inciso IV do mesmo dispositivo ${ }^{629}$.

É interessante atentar ao fato de que as conclusões se mantêm independentemente de se tratar de cessão de créditos tradicional ou de cessão apenas do fluxo desses créditos. A confusão ocorre sob o entendimento equivocado do conceito de true sale, havendo aqueles que entendam que a chamada true sale, que equivocadamente identificam com a cessão do crédito ao invés da cessão apenas do fluxo financeiro, seria essencial para a transferência substancial do risco ao cessionário. Contudo, não há relação entre um elemento e outro.

A chamada true sale aparece no contexto da preocupação dos adquirentes dos créditos (ou dos fluxos) de que estes não serão arrecadados em eventual falência do cedente ou que de a cessão não se sujeitará a ação revocatória em caso de falência do cedente ${ }^{630}$. No caso brasileiro, tal blindagem é assegurada pelo artigo 136, $\$ 1^{\circ}$ da Lei n. 11.101/2005, que estabelece que "[n]a hipótese de securitização de créditos do devedor, não será declarada a ineficácia ou revogado o ato de cessão em prejuízo dos direitos dos portadores de valores mobiliários emitidos pelo securitizador". Para valer-se de tal dispositivo, portanto, é irrelevante a existência ou não de coobrigação, bastando que a alienação seja definiti$\mathrm{va}^{631}$. Não há, portanto, relação entre o conceito de true sale ${ }^{632}$ e a cessão de créditos alternativamente à cessão apenas do fluxo financeiro gerado por tais créditos.

É importante ter em vista que em toda operação de securitização haverá custo financeiro, normalmente na forma de deságio ${ }^{633}$, apresentando-se como a forma por meio da

contábeis do cedente, tais como: (...) III - cessão de direitos creditórios para os quais o cedente ou parte relacionada, garanta, por qualquer forma, inclusive com a aquisição de cotas subordinadas, compensar o fundo, no mínimo, pelas perdas de crédito prováveis de ocorrer, observado o disposto no art. 40; e (...).”

629 "Art. $3^{\circ}(\ldots) \$ 2^{\circ}(\ldots)$ IV - quaisquer outros mecanismos, fora das condições normais de mercado, que visem mitigar a exposição ao risco de mercado ou de crédito do fundo, tais como recompra, substituição ou permuta de direitos creditórios ou ainda aporte de cotas subordinadas pelo cedente ou parte relacionada, de forma recorrente ou sistemática."

630 FAVERO JUNIOR, Osvaldo Zanetti. Securitização de ativos e transferência de risco: evidências do mercado de capitais brasileiro, pp. 50-1: "O significado da cessão definitiva utilizado no conceito de cessão sem coobrigação acima descrito possui um significado diverso do utilizado para explicar o conceito do termo true sale (termo emprestado do mercado norte-americano) ou venda efetiva, sendo este relacionado à impossibilidade dos ativos cedidos retornarem ao cedente no caso de falência deste (impossibilidade de recaracterização da operação). Este termo está ligado ao significado de uma blindagem (ou firewall) nos ativos transferidos, de forma que os credores do cedente não os alcancem em uma eventual falência, garantindo os investidores da EPE que seus direitos não serão diluídos com os dos credores do cedente, em caso de falência deste".

${ }^{631}$ FAVERO JUNIOR, Osvaldo Zanetti. Op. cit., p. 51. E na página 53: "Entende-se, portanto, que pelas características do ambiente regulatório brasileiro, as incertezas provenientes de uma eventual descaracterização do true sale não são significativas, independendo da forma de representação contábil. Mesmo porque, de acordo com as características das operações praticadas através dos FIDCs e em atendimento às diretrizes da Resolução n. 3533(2008), da Deliberação CVM n. 604(2009) ou da ICVM n. 408(2004), a maior parte das operaçôes de securitização de ativos através dos FIDCs estão on balance no cedente (são registradas contabilmente como empréstimos garantidos)."

${ }^{632}$ Vale lembrar que o conceito de true sale é de vital importância nas operações de securitização como elemento de isolação dos riscos dos créditos em relação aos riscos do cedente.

633 ROQUE, Pamela Romeu. Op. cit., p. 47. 


\section{•• Teoria jurídica do crédito público e operações estruturadas}

qual o titular dos valores mobiliários emitidos obterá o retorno do seu investimento. Este fato por si não significa que haverá prejuízos ao cedente dos créditos. Pelo contrário, especialmente no caso da cessão de créditos pendentes de pagamento e de difícil recuperação, mesmo um grande deságio pode representar obter algum valor de ativos que, na perspectiva do cedente e nas suas forças de cobrança e administração dos créditos, não têm nenhum potencial de geração de valor ${ }^{634}$.

Também não se pode dizer que a existência de deságio na cessão dos créditos para securitização seja elemento suficiente para caracterizar uma operação de crédito. O deságio não representa apenas o desconto decorrente da antecipação de um fluxo de caixa esperado, mas também e principalmente o risco deste fluxo de caixa. Quando o risco do fluxo de caixa é mantido sob responsabilidade do cedente, como no caso de um desconto de duplicata, é clara a realização de uma operação de crédito, sendo o deságio mera remuneração pelo adiantamento dos recursos, ligada ao risco de default do próprio cedente. Por outro lado, quando o risco do fluxo de caixa é transferido integralmente ao adquirente do crédito, então, o deságio refletirá principalmente o risco de default dos créditos cedidos, retratando o valor do ativo alienado e não apenas o custo do dinheiro no tempo.

Feitas as necessárias distinçōes de natureza econômica, jurídica e contábil, convém analisar o tratamento da questão na legislação brasileira, de maneira a identificar o regime jurídico das securitizações de ativos no setor público e suas possíveis consequências no âmbito do acompanhamento e controle do endividamento estatal.

Como demonstrado, as operações de securitização baseiam-se em negócio jurídico de cessão de créditos e não em negócio jurídico de mútuo ou de promessa de mútuo (abertura de crédito). Assim, ainda que se possa apontar semelhanças econômicas entre as securitizaçôes e os empréstimos ${ }^{635}$, do ponto de vista jurídico devem ser claramente identificados os pontos de divergência entre os institutos, de maneira a não pretender aplicar às operações de securitização as consequências aplicáveis às operações de crédito, na linha do contido na Constituição Federal, na Lei de Responsabilidade Fiscal e nas Resoluções do Senado Federal, especialmente as Resoluçōes SF n. 40/2001 e Resolução SF n. 43/2001.

O primeiro ponto a se notar com relação ao tema consiste no fato de que a Constituição Federal atribui ao Congresso Nacional, mediante lei complementar, a competência para tratar de operações de crédito e dívida pública, nos termos do artigo 48, $\mathrm{II}^{636}$, e do

634 ROQUE, Pamela Romeu. Op. cit., p. 48: "No âmbito das securitizações de créditos vencidos e não pagos, o deságio é um elemento ainda mais sensível. Com efeito, uma de suas particularidades é a de que as perdas já se concretizaram para o cedente e, consequentemente, o risco da inadimplência, na verdade, já é um fato presente. Segundo V. P ZICA, a cessão, nessa hipótese, por qualquer valor, representará recuperação imediata, receita líquida, quase sem custo e que ainda estancará os gastos de cobrança e gerenciamento.

De fato, a oportunidade de securitização de créditos vencidos e não pagos surge pela necessidade dos credores (futuros cedentes) encontrarem uma solução rápida para depurar seus balanços e monetizar créditos problemáticos, otimizando a alocação de capital e liberando recursos humanos e tecnológicos para geração e tratamento de novos ativos."

$635 \mathrm{O}$ que, como argumentado, se faz em grande medida em razão das regras de contabilização da operação em caso de não transferência substancial dos riscos e benefícios dos ativos cedidos.

636 "Art. 48. Cabe ao Congresso Nacional, com a sanção do Presidente da República, não exigida esta para o especificado nos arts. 49, 51 e 52, dispor sobre todas as matérias de competência da União, especial- 
artigo $163^{637}$. Assim sendo, não pode haver em norma infralegal ou em lei ordinária qualquer conceito de operação de crédito que viole as diretrizes fixadas na Constituição e as regras gerais estabelecidas na Lei Complementar n. 101/2000.

Com relação a este ponto, portanto, mister atentar para a redação do artigo 29, III ${ }^{638}$, da LRF, que traz o conceito de operação de crédito, e também para o artigo $37^{639}$ da mesma lei, que traz as hipóteses de equiparação a operações de crédito, que se encontram vedadas. Sobre essas hipóteses, deve-se ressaltar que não são propriamente operações de crédito. Se fossem, estariam abarcadas pelo conceito do artigo 29, III, e bastaria ao artigo 37 vedar o rol de espécies de operações de crédito que o legislador pretendia impedir aos entes públicos de realizar. Tendo tido o cuidado de utilizar a expressão "equiparam-se a operaçôes de crédito", o legislador corretamente notou que as operaçôes listadas não representam, do ponto de vista ontológico ou deontológico operaçōes de crédito, sendo a elas equiparadas e vedadas tão somente por semelhanças no plano axiológico.

Paralelamente, não se deve interpretar a expressão "e outras operaçôes assemelhadas" do artigo 29, III da LRF como autorização para interpretação ampliativa dos casos de operação de crédito. Isto, pois o artigo em referência é restritivo da liberdade de contratar dos entes federados e, portanto, é norma que deve seus limites à eficácia do princípio federativo $^{640}$. É necessária, portanto, a clara demonstração do vínculo objetivo entre a ope-

mente sobre: (...) II - plano plurianual, diretrizes orçamentárias, orçamento anual, operações de crédito, dívida pública e emissões de curso forçado."

637 “Art. 163. Lei complementar disporá sobre: I - finanças públicas; II - dívida pública externa e interna, incluída a das autarquias, fundações e demais entidades controladas pelo Poder Público; III - concessão de garantias pelas entidades públicas; IV - emissão e resgate de títulos da dívida pública; V - fiscalização financeira da administração pública direta e indireta; (Redação dada pela Emenda Constitucional n. 40, de 2003); VI - operaçóes de câmbio realizadas por órgãos e entidades da União, dos Estados, do Distrito Federal e dos Municípios; VII - compatibilização das funçôes das instituições oficiais de crédito da União, resguardadas as características e condições operacionais plenas das voltadas ao desenvolvimento regional."

638 “Art. 29. Para os efeitos desta Lei Complementar, são adotadas as seguintes definições: (...) III - operação de crédito: compromisso financeiro assumido em razão de mútuo, abertura de crédito, emissão e aceite de título, aquisição financiada de bens, recebimento antecipado de valores provenientes da venda a termo de bens e serviços, arrendamento mercantil e outras operações assemelhadas, inclusive com o uso de derivativos financeiros; $\$ 1^{\circ}$ Equipara-se a operação de crédito a assunção, o reconhecimento ou a confissão de dívidas pelo ente da Federação, sem prejuízo do cumprimento das exigências dos arts. 15 e 16."

639 "Art. 37. Equiparam-se a operações de crédito e estão vedados: I - captação de recursos a título de antecipação de receita de tributo ou contribuição cujo fato gerador ainda não tenha ocorrido, sem prejuízo do disposto no $\$ 7^{\circ}$ do art. 150 da Constituição; II - recebimento antecipado de valores de empresa em que o Poder Público detenha, direta ou indiretamente, a maioria do capital social com direito a voto, salvo lucros e dividendos, na forma da legislação; III - assunção direta de compromisso, confissão de dívida ou operação assemelhada, com fornecedor de bens, mercadorias ou serviços, mediante emissão, aceite ou aval de título de crédito, não se aplicando esta vedação a empresas estatais dependentes; IV assunção de obrigação, sem autorização orçamentária, com fornecedores para pagamento a posteriori de bens e serviços."

640 TORRES, Heleno Taveira. Direito Constitucional Financeiro: Teoria da Constituição Financeira, p. 449: "Questão tormentosa, portanto, reside na utilização da expressão 'e outras operações assemelhadas', o 
ração sob análise e os casos listados na enumeração do artigo 29, III, ou mesmo nos casos de operaçốes equiparadas a operações de crédito ${ }^{641}$.

Aproveitando-se da ideia de definitividade e transferência de riscos por meio da cessão de créditos, tanto a doutrina quanto órgãos de advocacia pública têm corretamente afastado as operações de securitização de ativos da ideia de operação de crédito, o que, no setor público, tem o efeito imediato de excluir a aplicação das restrições, limites e condições presentes na LRF e nas Resoluções SF n. 40/2001 e 43/2001 das referidas operações de securitização.

O Parecer PGFN/CAF/N. 2900/2007, por exemplo, da Procuradoria Geral da Fazenda Nacional (PGFN), trata de análise, em tese, de estrutura de operação sugerida pelo Banco do Brasil, envolvendo a constituição de Fundo de Investimentos em Direitos Creditórios para receber o produto de cessão de fluxo de caixa de estados e municípios decorrente do pagamento de créditos tributários confessados e incluídos em parcelamento.

Neste parecer, a PGFN já considerava a transferência completa do risco ao cessionário como o principal aspecto a se observar para a decisão de se caracterizar ou não a ope-

que permitiria a compreensão de que se está diante de definição exemplificativa, e não taxativa. Contudo, esta é mesmo regra limitativa da autonomia dos Estados, com afetação às finanças públicas dos entes estatais, com efeito sobre o próprio federalismo fiscal, o que impede qualquer recurso a interpretações ampliativas ou capazes de acrescer limites que a LRF não constitui. Com 'outras operaçôes assemelhadas', somente pode-se entender aquilo que se mantenha em conexão material ou causal com contratos de 'mútuo', de 'abertura de crédito', de 'emissão e aceite de título', de 'aquisição financiada de bens', de 'recebimento antecipado de valores provenientes da venda a termo de bens e serviços', de 'arrendamento mercantil' ou 'uso de derivativos financeiros'. Ou seja, somente terá o condão de se afirmar como 'operação de crédito' vedada pela LRF, ainda que na forma de 'novação', 'refinanciamento' ou 'postergação', alguma operação que mantenha identidade ou semelhança com estas modalidades, devido ao caráter taxativo e vinculante dos atos e negócios jurídicos defesos pela LRF." No mesmo sentido, SOUTO, Marcos Juruena Villela; ROCHA, Henrique Bastos. Securitização de recebíveis de royalties do petróleo: "A lei complementar federal impõe uma restrição na liberdade de atuação de todas as entidades federadas, que, por força do princípio federativo (arts. $1^{\circ}$ e 18, da CF/1988, são dotadas de autonomia, inclusive para a gestão de seus recursos.

Assim, considerando tratar-se de norma restritiva de direitos, a merecer interpretação fechada, poder-se-ia firmar uma linha de raciocínio, não livre de polêmica, que outras situações não foram abrangidas e, em razão disso, não haveria limitação à liberdade inerente à autonomia estadual."

641 TORRES, Heleno Taveira. Op. cit., p. 450: "Desse modo, para que determinada operação seja considerada assemelhada àquelas dispostas no art. 29 da LRF faz-se necessário um vínculo objetivo entre a operação considerada e aquelas listadas no dispositivo em questão. Por outro giro, se as equiparações realizadas pela própria lei mantêm uma relação objetiva com as operações de crédito expressamente referidas pelo art. 29, III, não restam dúvidas de que esse vínculo deve ser perquirido pelo intérprete ao pretender tratar determinada operação como assemelhada àquelas expressamente arroladas.” E novamente na página 451: "As citadas equiparações adotadas pela LRF bem revelam que o legislador não pretendeu conferir margem de discricionariedade ao intérprete, para alcançar pela definição legal de operaçôes de crédito situações dessemelhantes daquelas referidas até mesmo como 'equiparadas'. Feita essa delimitação material, não hã que se pretender sua extrapolação. Mesmo diante de uma miríade de operações que poderiam ser vistas como operações de crédito - não apenas aquelas expressas na LRF mas também as 'assemelhadas' - é defesa a inclusão, dentre as operações de crédito, de operações que não se apresentam como equivalentes.” 
ração como operação de crédito. Assim, em não havendo garantias por parte do ente cedente de um fluxo positivo específico decorrente dos créditos, não se poderia distinguir a operação de uma simples alienação de $\operatorname{ativos}^{642}$.

No ano de 2012, novamente, a PGFN manifestava-se sobre o assunto por meio do Parecer PGFN/CAF/N. 1975/2012, que tratava da análise da minuta de contrato de cessão de créditos decorrentes de participações especiais e royalties em função da exploração de petróleo e gás natural, entre o Banco do Brasil S/A e o Fundo Único de Previdência Social do Estado do Rio de Janeiro (RIOPREVIDÊNCIA).

No Parecer PGFN/CAF/N. 1975/2012 são apontados dois elementos como essenciais para que uma operação não possa ser caracterizada como uma operação de crédito: (i) a definitividade da cessão e (ii) a ausência de garantias ao adimplemento do crédito. Estando diante de operação que contemple ambas as características, a operação deverá ser reconhecida como simples operação de alienação de ativos, assemelhada a uma compra e venda. Nota-se que não há qualquer referência no Parecer à transferência substancial ou não de riscos do ativo ao adquirente ${ }^{643}$. A não transferência da totalidade dos riscos, assim, em nosso entendimento, representaria apenas um elemento indiciário da existência de garantias implícitas de adimplemento, o que precisaria ser inequivocamente demonstrado para que se pudesse falar em operação de crédito.

Finalmente, no Parecer PGFN/CAF n. 1579/2014, mais uma vez, a PGFN confirma os argumentos previamente apresentados, repisando a não existência de operação de crédito no caso de cessão de créditos sem compromisso de solvência por parte do cedente dos créditos ${ }^{644}$.

${ }^{642}$ Parecer PGFN/CAF/N. 2900/2007, p, 2: "Não haverá, da maneira como detalhada na Nota n. 1.674/ STN/COPEM, de 2007, assunção de riscos pelos Estados e Municípios, pois os recursos provenientes da cessão pretendida ingressarão definitivamente no orçamento do ente da federação que a contratar, não devendo este restituí-los futuramente ao cessionário, ainda que o fluxo de caixa decorrente do produto de parcelamento de dívidas confessadas seja inferior ao montante por ele pago.Enfim, não há outra obrigação para os entes além da entrega ao FIDC do fluxo de recebimentos oriundos de parcelamento.Trata-se, portanto, de alienação de ativos definitiva, sem assunção de riscos pelos entes da federação, o que, conforme precedentes desta Procuradoria-Geral, não se enquadra no conceito de operação de crédito."

643 Parecer PGFN/CAF/N. 1975/2012, p. 1: "O tema relativo à natureza jurídica das cessões de receitas provenientes de créditos decorrentes de exploração de recursos naturais a que fazem jus os entes da Federação já foi objeto de reiteradas manifestaçôes desta Procuradoria-Geral da Fazenda Nacional, sendo pacífico o entendimento de que tais operações só não se caracterizam como operação de crédito se elas forem definitivas, assemelhadas a uma compra e venda à vista de um bem incorpóreo - o crédito. Para tanto, o cedente não pode conceder qualquer tipo de garantia de adimplemento, ou seja, não deve haver qualquer outra obrigação para o cedente além do repasse ao cessionário do fluxo de recebimentos oriundos da compensação financeira."

${ }^{644}$ Parecer PGFN/CAF n. 1579/2014: "Na cessão do fluxo financeiro decorrente de créditos inscritos em dívida ativa, não é transferida a titularidade do crédito pelo cedente ao cessionário (que permanece, pois, no ativo do primeiro), mas tão somente o fluxo financeiro decorrente dos pagamentos efetuados pelos devedores ao credor. Desde que inexistente, no caso concreto, obrigação por parte do cedente de garantir eventual crédito inadimplido pelo devedor - seja em dinheiro, seja substituindo-o por outro crédito -, não há que se falar em operação de crédito, já que inexistiria obrigação de pagar por parte do cedente, 


\section{•- Teoria jurídica do crédito público e operações estruturadas}

É semelhante o entendimento da Procuradoria Geral do Estado de São Paulo, em parecer subscrito por Mário Engler Pinto Junior. Contudo, neste parecer, é ainda realizada importante distinção entre operações a título de antecipação de receitas e operações de securitização de recebíveis.

A importância de tal distinção reside no fato de que o artigo 37 da LRF considera operação equiparada à operação de crédito e vedada a operação de captação de recursos a título de antecipação de receita de tributo ou contribuição cujo fato gerador ainda não tenha ocorrido. Este não é o caso, porém, das operaçôes de securitização de recebíveis decorrentes de parcelamentos tributários que se tem realizado no Brasil, visto que, nestas operações, ao contrário, encontram-se créditos já constituídos, decorrentes de fatos geradores passados. Esse mesmo motivo é suficiente para distinguir a securitização de simples operação de crédito por antecipação de receita orçamentária, na qual há a obrigação de devolução do valor integralmente adiantado e que não faz referência necessariamente a tributos devidos por fatos geradores já ocorridos ${ }^{645}$.

Assim, também esse parecer se filia à tese de que a característica fundamental para que se possa classificar uma operação de cessão de créditos como uma operação de crédito é a existência de garantia ao correto pagamento dos créditos pelos devedores cedidos ${ }^{646}$.

A mesma opinião é defendida por Carlos Ari Sundfeld, que apresenta relevante argumento contra a caracterização como operação de crédito nas operações de cessão onerosa de direitos creditórios decorrentes de parcelamentos tributários. Segundo esse autor, nessas operações de cessão, não se estaria antecipando receita, na medida em que a receita

mas, apenas obrigação de fazer, no caso, repassar ao cessionário o numerário entregue ao credor pelo devedor inscrito em dívida ativa. Tal entendimento permanece verdadeiro, mesmo no caso de o cedente se obrigar a cobra judicialmente o crédito não adimplido, tendo em vista que tal obrigação não se caracteriza enquanto obrigação de pagar, mas se fazer."

645 Consultoria Jurídica da Secretaria da Fazenda do Governo do Estado de São Paulo. Parecer n. 611/2010, p. 15: "O Contrato de Cessão pretende antecipar o recebimento de ICMS cujo fato gerador já ocorreu, por se tratar de crédito tributário definitivamente constituído e reconhecido pelo contribuinte devedor. Portanto, o negócio jurídico a ser celebrado entre o Estado e a CPSEC não se enquadra na categoria de antecipação de receita orçamentária (cf. art. 38), devendo ser considerado como hipótese não vedada de antecipação de receita tributária (cf. art. 37, I). A receita tributária antecipada possui desde logo existência legal, embora ainda não tenha se materializado financeiramente. A realização financeira ocorrerá ao longo do tempo, na medida em que os créditos parcelados forem sendo pagos espontaneamente pelo sujeito passivo ou recuperados coativamente pelo sujeito ativo."

646 Consultoria Jurídica da Secretaria da Fazenda do Governo do Estado de São Paulo. Parecer n. 611/2010, pp. 15-6: "A vinculação do fluxo financeiro gerado pelos créditos tributários parcelados, em cumprimento de obrigação contraída pelo Estado no Contrato de Cessão, somente será considerada operação de crédito sob a ótica da Lei de Responsabilidade Fiscal, se o Estado ficar responsável perante a cessionária CPSEC pelo efetivo pagamento dos Direitos Creditórios pelos contribuintes devedores. Qualquer garantia dada pelo Estado nesse particular caracterizaria compromisso financeiro assumido em razão do recebimento antecipado de valores provenientes da venda a termo de bens e serviços, forçando a equiparação do negócio de cessão a operação de crédito, nos termos do artigo 29, III, da LRF. Nesse caso, a realização da operação dependeria de prévia aprovação das autoridades federais (cf. art. 31, Resolução do Senado n. 43, de 2001), além de o montante antecipado ser incorporado no estoque da dívida do Estado para efeito de aplicação dos limites cabíveis." 
já estaria constituída, ainda que não arrecadada. Isto, pois, nos casos de parcelamento tributário, não se pode falar de fato gerador a ocorrer ${ }^{647}$.

Esse argumento ganha ainda mais força em vista das modificações recentes nas normas de contabilidade aplicadas ao setor público, que exigem a adoção do regime de competência para o reconhecimento de receitas públicas. Assim, ainda que não arrecadadas e recolhidas aos cofres públicos, as receitas lançadas e, portanto, constituídas já devem ser reconhecidas contabilmente, dando lastro à existência de um ativo no balanço patrimonial da entidade pública.

Nesta linha, verifica-se que os elementos que são considerados pela doutrina jurídica como essenciais na separação de atividades de financiamento por meio de operações de crédito de simples operaçôes de cessão de créditos (logo, alienação de bens), foram adotados pela Resolução n. 11/2015 do Senado Federal, que deu nova redação ao artigo 5º da Resolução n. 43/2001 do Senado Federal, tendo sido, posteriormente, modificada pela Resolução n. 17/2015 $5^{648}$. Esta resolução foi aprovada com o objetivo de tratar das operaçôes de securitização de parcelamentos tributários, mais especificamente, operações envolvendo créditos inscritos em dívida ativa.

Assim é que a redação atual do artigo $5^{\circ}$, VII, veda as operações de cessão de fluxos de recebimentos de direitos creditórios (apenas de dívida ativa, deve-se ressaltar) que não sejam definitivas ou que envolvam a concessão de garantias de solvência dos créditos em relação ao adquirente. Ou seja, o Senado Federal proíbe expressamente, na Resolução n. 43/2001, qualquer operação de crédito realizada por meio de cessão de créditos inscritos em dívida ativa. Isso não significa que o Senado Federal proíba todas as operações de securitização de crédito inscritos em dívida ativa, afinal, careceria o Senado de competência constitucional para tanto, mas apenas que o Senado pró́be as operações de crédito realizadas por meio da cessão de créditos inscritos em dívida ativa, sendo os critérios definitividade e ausência de garantia de adimplemento os elementos definidores da natureza da operação.

647 SUNDFELD, Carlos Ari. Opinião legal fornecida ao Banco do Estado do Rio Grande do Sul, relativa a operação envolvendo o Estado do Rio Grande do Sul e a Caixa de Administração da Dívida Pública Estadual S/A - CADIP, p. 4: "Mas as receitas que denominamos de passadas - os créditos oriundos dos parcelamentos - são, ao contrário, plenamente alienáveis, como, aliás, é reconhecido tanto pela doutrina como por normas vigentes (cite-se, novamente, o Convênio ICMS 104/02).Quando o Estado aliena onerosamente tais receitas ele não está fazendo uma antecipação do futuro, mas uma recuperação do passado. Por isso, não se trata de endividamento. Não há, portanto, submissão aos limites previstos no art. 52 da Constituição, razão por que não há necessidade de manifestação prévia da Secretaria do Tesouro Nacional."

648 "Art. 50 É vedado aos Estados, ao Distrito Federal e aos Municípios: (...) VII - em relação aos créditos inscritos em dívida ativa: a) ceder o fluxo de recebimentos relativos aos direitos creditórios da dívida ativa de forma não definitiva ou com cláusula revogatória; (Inciso com redação dada pela Resolução n. 17, do Senado Federal, de 11/11/2015) b) ceder o fluxo de recebimentos relativos aos direitos creditórios da dívida ativa com assunção, pelo Estado, pelo Distrito Federal ou pelo Município, perante o cessionário, de responsabilidade pelo efetivo pagamento a cargo do contribuinte ou de qualquer outra espécie de compromisso financeiro que possa, nos termos da Lei Complementar n. 101, de 4 de maio de 2000, caracterizar operação de crédito. (Inciso com redação dada pela Resolução n. 17, do Senado Federal, de 11/11/2015) c) (Inciso acrescido pela Resolução n. 11, do Senado Federal, de 31/8/2015, e revogado pela Resolução n. 17, do Senado Federal, de 11/11/2015).” 


\section{•• Teoria jurídica do crédito público e operações estruturadas}

Nesta ordem de considerações, deve-se observar que em análise constante do Parecer n. 1.019/2015 ao Projeto de Resolução do Senado PRS n. 50, o Relator do Parecer no Senado Federal deixou evidente a intenção de reduzir os óbices para que estados e municípios realizem a cessão de direitos creditórios de dívida ativa, desde que não envolvam a assunção de qualquer tipo de garantia por parte do cedente. Assim verifica-se que o principal objetivo das Resoluções n. 11 e 17, de 2015, sempre foi o de facilitar as operações de securitização de créditos de dívida ativa, conforme reconheceu a própria Comissão de Assuntos Econômicos do Senado Federal ${ }^{649}$ (CAE), no Parecer CAE n. 463/2016, de Relatoria do Senador Lindbergh Farias, que trata do Aviso n. 21, de 2016, do Tribunal de Contas da União, que encaminha cópia do Acórdão n. 772/2016 - TCU, com o entendimento preliminar da área técnica do TCU de que as operações de securitização realizadas por estados e municípios poderiam configurar operação de crédito, nos termos dos artigos 29 e 37 da LRF.

Neste ponto, cabe mais uma vez recordar que não cabe ao Senado Federal fixar o conceito de operação de crédito, mas apenas dispor sobre os seus limites globais e condiçôes. A atribuição de dispor sobre operações de crédito é privativa do Congresso Nacional, conforme prevê o citado artigo 48, II, da Constituição Federal.

Tendo isso em vista, ressalta-se que, no mesmo Parecer da CAE, o Relator também debate a questão do reforço de crédito, posicionando-se no sentido de que não é bastante para configurar operação de crédito que a securitização conte com mecanismos de reforço de crédito, na modalidade de garantia parcial implícita ${ }^{650}$, na linha do que já argumentado no presente trabalho. Portanto, para que as garantias possam caracterizar a operação de crédito, é necessário que claramente se mostrem excessivas, a representar verdadeiro compromisso de adimplemento dos créditos cedidos.

Antes de passar à análise do impacto fiscal das operações de securitização, vale observar a estranha guinada dada pela Procuradoria Geral da Fazenda Nacional no ano de 2016, por meio do Parecer PGFN/CAT n. 1894/2016 ${ }^{651}$, o qual, em contradição com os pareceres

649 Parecer CAE n. 463/2016, Relator Senador Lindbergh Farias, p. 11: “Observe-se que, na Análise constante do Parecer n. 1.019, de 2015, referente ao Projeto de Resolução do Senado (PRS) n. 50, fica patente o objetivo do Relator de reduzir as dificuldades para que municípios e estados cedam onerosamente os direitos creditórios da dívida ativa. Há, sem dúvida, preocupação em proibir a assunção de qualquer tipo de garantia por parte do cedente, mas, claramente, não há qualquer intenção de vedar tais operações. Pelo contrário, como dissemos, o objetivo maior das Resoluçóes n. 11 e 17, de 2015, era facilitar tais operações."

650 Parecer CAE n. 463/2016, Relator Senador Lindbergh Farias, p. 15: "Em tese, não haveria problemas em oferecer garantias. Isso não transformaria a venda de um ativo em um empréstimo. Na década passada, por exemplo, vários bancos, por determinação do Banco Central, tiveram de desmobilizar seus ativos e passaram a vender seus imóveis. Em vários leilóes, o imóvel era vendido com a garantia de pagamento mínimo de aluguel durante determinado período. Essa garantia não altera a natureza econômica de venda do ativo, apenas altera o preço que as pessoas estarão dispostas a pagar pelo imóvel. Por outro lado, o oferecimento de garantia (ou instrumentos assemelhados) pode ser transformado em operação de empréstimo se essas garantias forem excessivas."

651 É possível que a contradição decorra do fato de que este parecer foi emitido por outra coordenadoria (PGFN/CAT), enquanto os anteriores eram de autoria de PGFN/CAF. Essa seria uma explicação baseada na desordem administrativa, não em argumentos jurídicos, não sendo razoável que uma divisão de 
anteriores do órgão, fez grave confusão entre os conceitos de definitividade de cessão de crédito e poderes de cobrança do crédito, em operações com cessão de fluxo financeiro.

De maneira a piorar ainda mais o cenário e contribuir negativamente com a insegurança jurídica sobre o tema, a Secretaria do Tesouro Nacional publicou em 2018 a Instrução de Procedimentos Contábeis IPC 13 - Cessão de direitos creditórios, com orientações de procedimentos contábeis a serem adotados por estados e municípios em operações de securitização.

O documento Instruções de Procedimentos Contábeis IPC 13, produzido pela Secretaria do Tesouro Nacional para observância por todos os entes públicos nacionais, embora tenha como ponto positivo a previsão dos lançamentos contábeis a serem adotados conforme a espécie de cessão de direitos creditórios (se com transferência de riscos ou sem transferências de riscos), incorre em grave equívoco, na classificação das operações, confundindo-se, na esteira do Parecer PGFN usado como fundamento para elaboração do IPC, na aplicação de conceitos jurídicos como "cessão de fluxo de recebíveis", "cessão com coobrigação" e "cessão definitiva", concluindo ser impossível a cessão de fluxo de recebíveis com retenção da titularidade do crédito e da cobrança, sem que sejam retidos riscos substanciais.

Ora, esta conclusão não é de natureza contábil, mas jurídica, nem pode ser feita sem avaliação cuidadosa dos documentos da operação, os quais devem dispor sobre os direitos e obrigações das partes envolvidas. Deve-se, portanto, analisar com cautela o alcance do IPC 13 e seus efeitos sobre as operações desenvolvidas especialmente por estados e municípios. Como exemplos da mencionada confusão no IPC 13, podem-se citar os seguintes trechos selecionados:

A. "15. Dentre os modelos de cessão com coobrigação, o mais utilizado é a securitização. (...)"652 Ora, há securitizações realizadas com e sem coobrigação, sendo o mais comum inclusive no mercado privado exatamente o oposto do previsto no IPC, ou seja, securitizações sem coobrigação);

B. “(...) entende-se que para que seja caracterizada a cessão definitiva e, por conseguinte a alienação de ativos, o controle do recurso há de ser transferido integralmente." ${ }^{53}$ Ao contrário do afirmado no trecho, a cessão definitiva se opõe a uma cessão sujeita a condição, isto é, sujeita a uma cláusula acidental do tipo regulado pelos artigos 121 e seguintes do Código Civil e não a uma cessão de fluxo financeiro alternativa a uma cessão de crédito.

C. "Por fim, este órgão entende que, nos casos em que Estados e Municípios editaram leis que permitem a cessão onerosa de créditos tributários, por meio de SPE

um mesmo órgão possa ignorar entendimentos consolidados do p oprio órgão, nem que um órgão jurídico possa sujeitar análises jurídicas a opiniōes, por mais qualificadas que sejam, de órgãos que não detém a competência legal ou técnica para a análise jurídica, como é o caso da STN.

${ }^{652}$ SECRETARIA DO TESOURO NACIONAL (STN). Instrução de procedimentos contábeis IPC 13 Cessão de direitos creditórios, p. 6.

653 SECRETARIA DO TESOURO NACIONAL (STN). Op. cit., p. 8. 
ou FIDC ou qualquer entidade criada para este fim, sem alterar sua natureza jurídica, nem modificar a sujeição ativa do tributo, ou seja, sem transmitir a titularidade dos referidos créditos, o registro contábil mais apropriado é o assemelhado ao de operações de crédito do tipo empréstimos com garantia." ${ }^{654}$ Neste trecho, a STN conclui, sem fazer referência às condições de assunção de risco próprias de cada operação, que a simples decorrência de se tratarem de operações de cessão de créditos tributários seriam suficientes para o registro como empréstimos com garantia. Contudo, não seria difícil se apresentar um contra-argumento, bastando se imaginar a situação de uma cessão não sujeita a condição suspensiva ou resolutiva (ou seja, definitiva) de fluxo financeiro sem qualquer cobertura na forma de (i) debêntures ou cotas subordinadas; (ii) obrigação de reposição de créditos não performados; (iii) obrigação de compensação por créditos não performados. Esse caso limite se enquadraria perfeitamente à hipótese mencionada no trecho destacado, sem, contudo, apresentar qualquer semelhança jurídica ou econômica a uma operação de crédito, na qual a obrigação de devolução dos recursos pelo seu valor nominal (ou às vezes real) é característica central e fundamental. Nota-se, por conseguinte, que a generalização apresentada no IPC 13 é desprovida de fundamento jurídico.

A confusão ocorre, em nossa opinião, em parte por conta do interrelacionamento entre Direito e Contabilidade em diversos dos temas relacionados ao direito privado dos negócios. Se a incorreta extrapolação de efeitos jurídicos a partir de ideias contábeis já é corriqueira entre os praticantes do direito privado, em tese mais acostumados aos institutos do direito empresarial, com ainda maior incidência poderá ocorrer equívocos entre os praticantes do direito público, considerando-se a novidade que é para grande parte dos entes públicos a realização de operações estruturadas, entre as quais operações de securitização. Este fato revela a importância da dedicação da dogmática jurídica ao tema do presente trabalho.

Os objetivos da Contabilidade não coincidem com os objetivos do Direito. A Contabilidade é o conjunto de conhecimentos e técnicas voltados ao registro de fatos com impacto sobre o patrimônio de uma organização. Seu interesse principal é na geração de informações, por meio de relatórios, que reflitam da maneira mais fiel o possível o valor do patrimônio da organização em todas as suas componentes, bem como o resultado de suas atividades $^{655}$. O Direito, por sua vez, tem como um de seus valores fundamentais a ideia de segurança e de estabilização das expectativas na sociedade, visando à pacificação dos conflitos. Neste contexto, embora se tratem de ramos do conhecimento que com frequência se cruzam, não é correto, do ponto de vista metodológico, pretender extrair de procedimentos contábeis consequências definitivas em matéria jurídica. Esse equívoco, muito comum na área do direito financeiro, comercial, econômico e tributário, tende a conduzir a conclusões juridicamente erradas, baseadas em uma petição de princípio (petitio principii).

654 SECRETARIA DO TESOURO NACIONAL (STN). Op. cit., p. 10.

655 IUDÍCIBUS, Sérgio de; MARION, José Carlos. Contabilidade comercial, p. 5. 
A questão é suficientemente relevante, em nosso entendimento, para que apresentemos um exemplo, de maneira a mais bem apresentar a distinção de objetivos entre Direito e Contabilidade e o fato de que não se pode pretender extrair consequências jurídicas exclusivamente da forma de apresentação contábil de uma determinação operação.

Um exemplo dessa distinção de tratamento consiste nas regras contábeis para reconhecimento de ativos. Conforme o item 5.6 da Norma Brasileira de Contabilidade, NBC TSP Estrutura Conceitual, de 23 de setembro de 2016, aprovada pelo Conselho Federal de Contabilidade, de acordo com o Pronunciamento intitulado The Conceptual Framework for General Purpose Financial Reporting by Public Sector Entities, emitido pelo International Public Sector Accounting Standards Board da International Federation of Accountants (IPSASB/IFAC), ativo é "um recurso controlado no presente pela entidade como resultado de evento passado", sendo que para avaliar se a entidade controla o recurso no presente, deve ser observada a existência dos seguintes indicadores de controle: (i) propriedade legal; (ii) acesso ao recurso ou a capacidade de negar ou restringir o acesso a esses; (iii) meios que assegurem que o recurso seja utilizado para alcançar os seus objetivos; ou (iv) a existência de direito legítimo ao potencial de serviços ou à capacidade para gerar os benefícios econômicos advindos do recurso, reconhecendo-se ainda que, embora esses indicadores não sejam determinantes e conclusivos acerca da existência do controle, sua identificação e análise podem subsidiar essa decisão ${ }^{656}$.

Conforme se verifica, contabilmente, um bem ou um direito pode ser considerado como integrante do patrimônio de uma determinada entidade, sem que legalmente a propriedade seja sua, bastando para tanto que os benefícios econômicos daquele bem ou direito fluam para essa entidade, assim como os riscos a que este bem ou direito está su-

656 “Ativo. Definição. 5.6 Ativo é um recurso controlado no presente pela entidade como resultado de evento passado. Recurso. 5.7 Recurso é um item com potencial de serviços ou com a capacidade de gerar benefícios econômicos. A forma física não é uma condição necessária para um recurso. O potencial de serviços ou a capacidade de gerar benefícios econômicos podem surgir diretamente do próprio recurso ou dos direitos de sua utilização. Alguns recursos incluem os direitos da entidade a uma série de benefícios, inclusive, por exemplo, o direito a: (a) utilizar o recurso para a prestação de serviços (inclusive bens); (b) utilizar os recursos de terceiros para prestar serviços como, por exemplo, arrendamento mercantil; (c) converter o recurso em caixa por meio da sua alienação; (d) beneficiar-se da valorização do recurso; ou (e) receber fluxos de caixa. (...) 5.12 Para avaliar se a entidade controla o recurso no presente, deve ser observada a existência dos seguintes indicadores de controle: (a) propriedade legal; (b) acesso ao recurso ou a capacidade de negar ou restringir o acesso a esses; (c) meios que assegurem que o recurso seja utilizado para alcançar os seus objetivos; ou (d) a existência de direito legítimo ao potencial de serviços ou à capacidade para gerar os benefícios econômicos advindos do recurso. Embora esses indicadores não sejam determinantes conclusivos acerca da existência do controle, sua identificação e análise podem subsidiar essa decisão. 5.12 A A propriedade legal do recurso, tal como terreno ou equipamento, é um dos métodos para se verificar o potencial de serviços ou os benefícios econômicos de um ativo. No entanto, os direitos ao potencial de serviços ou à capacidade de gerar benefícios econômicos podem existir sem que se verifique a propriedade legal do recurso. Por exemplo, os direitos ao potencial de serviços ou à capacidade de gerar benefícios econômicos por meio da manutenção e utilização de item patrimonial arrendado são verificados sem que haja a propriedade legal do próprio item arrendado. Portanto, a propriedade legal do recurso não é uma característica essencial de um ativo. No entanto, a propriedade legal é um indicador de controle." 


\section{•• Teoria jurídica do crédito público e operações estruturadas}

jeito sejam suportados por essa entidade. Este fato é reconhecido pela própria norma contábil, não fazendo qualquer sentido alegar que juridicamente a propriedade seja transferida unicamente por conta do reconhecimento de um ativo em uma determinada entidade e da sua consequente baixa em outra entidade, por decorrência do respeito às normas contábeis. Reflexamente, não cabe ao Direito determinar como deverá ocorrer a contabilização de um determinado fato, considerando-se que este fenômeno é objeto de outra ciência, com princípios e técnicas diversos.

Feita essa ressalva, convém, finalmente, analisar a questão relativa aos impactos da securitização sobre as gerações seguintes, avaliando as eventuais restrições dessa natureza à sua realização. Nessa linha, argumenta-se que careceria de legitimidade cessão de créditos relativos a exercícios posteriores ao encerramento do mandato do chefe do Poder Executivo, sob o fundamento de que assim o gestor estaria onerando as futuras gerações e prejudicando a realização do programa político dos próximos mandatários ${ }^{657}$.

Não dividimos a opinião quanto à limitação da cessão de créditos relativos a exercícios posteriores ao encerramento do mandato do chefe do Poder Executivo como regra geral. Primeiramente, é preciso observar que tal regra encontra-se expressa apenas quanto à participação governamental obrigatória, nas modalidades de royalties, participaçóes especiais e compensações financeiras, no resultado da exploração de petróleo e gás natural, de recursos hídricos para fins de energia elétrica e de outros recursos minerais (artigo 5o, VI, $a$ e $b$ da Resolução SF n. 43/2001), não se aplicando automaticamente para as demais espécies de cessão de créditos. No mais, não é verdade que qualquer cessão comprometa o equilíbrio intergeracional, sendo certo que há aplicações para os recursos antecipados que poderão gerar resultados para as gerações vindouras, sendo esse o aspecto essencial a se observar.

Nesta linha de pensamento, mister observar que a legislação financeira já conta com regras de resguardo no sentido de evitar o desequilíbrio intergeracional na aplicação de tais recursos, sendo a principal delas a limitação de aplicação de receitas de alienação de bens em despesas de capital, na forma do artigo 44 da LRF ${ }^{658}$. Ademais, entende-se que o controle político realizado pelo Poder Legislativo na autorização da alienação dos direitos creditórios para a securitização aproxima-se do controle existente para as operaçôes de crédito, que pressupõe a existência de autorização legislativa específica (artigo 32, $₫ 1^{\circ}$, I, da LRF).

Sobre esse ponto, vale observar que os direitos creditórios cedidos em uma operação de securitização são juridicamente considerados bens móveis, motivo pelo qual a sua alie-

657 SOUTO, Marcos Juruena Villela; ROCHA, Henrique Bastos. Securitização de recebíveis de royalties do petróleo. “(...) em se tratando de alienação de bem estadual, mais uma vez se impóe a autorização legislativa para a operação. Sob o aspecto da legitimidade, impõe-se desde logo apontar que a operação deve ser limitada ao mandato dos atuais governantes; isto porque não se pode comprometer o recebimento de receitas futuras com o atual programa político, posto que destinadas ao atendimento de programas a serem executados por futuros governos (evitando, assim, o citado conflito intergeracional)."

658 "Art. 44. É vedada a aplicação da receita de capital derivada da alienação de bens e direitos que integram o patrimônio público para o financiamento de despesa corrente, salvo se destinada por lei aos regimes de previdência social, geral e próprio dos servidores públicos." 
nação dispensaria autorização legislativa, nos termos do artigo 17, II, da Lei n. 8.666/1993. Nada obstante, a prática dessas operaçôes no Brasil vem se dando com prévia autorização legislativa, como forma de mitigar riscos jurídicos e políticos que poderiam inviabilizar a demanda do mercado por títulos emitidos com lastro nos direitos creditórios cedidos. Embora despicienda, com base na legislação vigente, a prática é recomendável também do ponto de vista do equilíbrio intergeracional, na medida em que permite a realização de um debate mais amplo a respeito dos custos e dos benefícios da realização da operação.

Conforme se buscou demonstrar, as operações de securitização de ativos consistem em expediente próprio do mercado de capitais cada vez mais utilizado por entes estatais como alternativa para a obtenção de recursos para financiamento de despesas, sobretudo despesas de capital. Ainda que, em regra, as securitizações partam de um negócio jurídico de cessão de créditos, alinhando-se a uma lógica própria da alienação de bens, a semelhança econômica da operação às operações de crédito tem causado incerteza na doutrina e entre os administradores públicos e órgãos de controle, na aplicação do instituto.

Ainda que a securitização possa se aproximar, do ponto de vista econômico e contábil, de uma operação de crédito, daí não se pode induzir que se trate juridicamente de uma operação de crédito, nos limites do conceito fixado pela Lei Complementar n. 101/2000. Do ponto de vista jurídico, ao contrário, as operações de securitização, via de regra, envolvem a transferência - ainda que não integral - dos riscos e benefícios relativos aos ativos cedidos aos investidores subscritores dos valores mobiliários emitidos. Assim, a operação se distingue das operações de crédito, em que não há risco para os emprestadores além do risco normal de crédito do tomador dos recursos.

Nada obstante, reconhece-se que, no contexto atual, ainda há grande incerteza quanto à aplicação das regras da LRF às operações de securitização, em parte devido à escassez de trabalhos científicos sobre o tema do ponto de vista jurídico. Assim, os administradores públicos, instituições financeiras que atuam como intermediárias e também os órgãos de controle se veem obrigados a recorrer a trabalhos de outras áreas correlatas, tais como Contabilidade e Economia, que, embora auxiliem na compreensão da operação, não têm o necessário cuidado terminológico no tratamento dos conceitos jurídicos, provocando com frequência confusões desnecessárias.

\subsubsection{Constituição de fundos de investimentos e fundos públicos especiais}

Os fundos de investimento são organizados na forma de condomínios, fechados ou abertos, desprovidos de personalidade jurídica e criados a partir de um ato de vontade do seu administrador, que aprova o seu regulamento e oferta as suas cotas ${ }^{659}$. Como veículos

659 EIZIRIK, Nelson et al. Mercado de capitais: regime jurídico, p. 78: "Os fundos de investimento são constituídos pelo administrador, que elabora o regulamento e o prospecto, ofertando publicamente as cotas de emissão do fundo ao mercado (artigo $3^{\circ}$ da Instrução CVM 409/2004). Por sua vez, os investidores que adquirem estas cotas passam à condição de cotistas do fundo, mantendo nele sua aplicação.” E continua na mesma página 78: "Os fundos de investimento organizam-se, juridicamente, sob a forma de condomínio, sem personalidade jurídica, constituindo uma comunhão de recursos destinados à apli- 


\section{•• Teoria jurídica do crédito público e operações estruturadas}

de investimento e aplicação de recursos, os fundos de investimento possuem características que podem impactar as finanças públicas, especialmente quanto ao modo e à transparência relativa à aplicação dos recursos públicos.

A doutrina brasileira consolidou-se, em face da expressa menção do direito positivo, no sentido de aceitar que os fundos de investimento são condomínios sui generis, muito embora possuam semelhanças com institutos como as sociedades despersonalizadas. Contudo, fato é que há grande variedade de teorias a respeito da natureza dos fundos de investimento, tais como (i) Teoria Condominial; ii) Teoria da Comunidade de Bens não Condominial; iii) Teoria da Propriedade em Mão Comum; iv) Teoria da Propriedade Fiduciária; e, v) Teoria da Organização Associativa ${ }^{660}$.

Embora sejam desprovidos de personalidade jurídica, as cotas do fundo de investimento não se confundem com o patrimônio do fundo, sendo valor mobiliário representativo de fração do patrimônio deste sem com ele se confundir. Esta é uma característica de extrema relevância para a dinâmica dos fundos de investimento no mercado de capitais, na medida em que afasta a possibilidade de execução do patrimônio do fundo por dívidas dos seus cotistas, reduzindo assim os riscos do investimento conjunto ${ }^{661}$.

Sob esta perspectiva, afirma-se que os fundos de investimento representam a adoção no direito brasileiro de elementos dos chamados trusts oriundos do direito anglo-saxão ${ }^{662}$, por meio do qual se admite a existência de uma dupla relação de propriedade com o bem, sendo a propriedade do trustee meramente fiduciária. Neste contexto, deixa o bem de pertencer ao original titular para se agregar a um patrimônio de afetação administrado por instituição devidamente habilitada. Contudo, tal patrimônio não é de livre disposição pelo administrador-trustee, devendo respeitar as condições e regras de afetação. Também por esta razão, tais bens não se confundem com os bens particulares dos administradores, não respondendo por dívidas destes ${ }^{663}$, o que é de central relevância para a existência dos citados fundos como veículos de investimentos coletivos.

cação em carteiras compostas pelos mais diversos ativos financeiros, como títulos da dívida pública, açôes, debêntures e outros títulos ou contratos existentes no mercado."

660 Sobre esse tema ver CARVALHO, Márcio Tavernard Martins de. Regime jurídico dos fundos de investimento, passim. Cf. também EIZIRIK, Nelson et al. Mercado de capitais: regime jurídico, p. 78, n. 122: "Existem diversas correntes a respeito da natureza jurídica dos fundos de investimento, a saber: a) Teoria Condominial; b) Teoria da Comunidade de Bens não Condominial; c) Teoria da Propriedade em Mão Comum; d) Teoria da Propriedade Fiduciária; e) Teoria da Organização Associativa."

${ }^{661}$ EIZIRIK, Nelson et al. Mercado de capitais: regime jurídico, p. 87: "As cotas são representativas de frações ideais do patrimônio do fundo, adotando as formas escriturais e nominativas. $\mathrm{O}$ valor das cotas varia de acordo com a valorização do patrimônio do fundo (artigo 10 da Instrução CVM n. 409/2004).”

${ }_{662}$ CHALHUB, Melhim Namem. Negócio fiduciário, p. 363: "A Lei n. 4.728, de 1965, abriu perspectivas para assimilação, no ordenamento nacional, de elementos essenciais do instituto anglo-americano do trust, pelo menos na modalidade específica de investimento."

663 CHALHUB, Melhim Namem. Negócio fiduciário, p. 363: "O Fundo tem patrimônio autônomo, separado do patrimônio da sociedade administradora, permanecendo imune aos efeitos de eventual insolvência desta. $\mathrm{Na}$ sua configuração se pode reconhecer um condomínio de natureza especial, com patrimônio próprio, contabilidade específica, capacidade de representação em juízo e administração por uma espécie de trustee." 
Os fundos de investimento, portanto, ao contrário de serem simples vinculação de receitas, são, em verdade, patrimônio afetado a uma determinada finalidade, cuja titularidade se expressa por meio de valores mobiliários.

Tradicionalmente, a ideia de patrimônio estava intimamente vinculada à ideia de personalidade, representando o conjunto de relações jurídicas ativas e passivas da pessoa, por meio do qual se garantiria o cumprimento das suas obrigações, de maneira geral. Esta é a concepção da chamada "teoria subjetiva" do patrimônio ${ }^{664}$, desafiada pela existência de casos legais de redução do patrimônio como garantia indivisível das dívidas do seu titular, como ocorre com o instituto do bem de família e do fideicomisso, por exemplo ${ }^{665}$.

Contudo, modernamente, a teoria subjetiva deu lugar à teoria do patrimônio de afetação, por meio da qual se compreende no patrimônio um conjunto de relações jurídicas unidas por uma finalidade, qual seja a de servir a um fim econômico determinado ${ }^{666}$. Assim, o patrimônio se liga ao seu titular, na medida em que apresenta como finalidade servir de garantia para as obrigações por este assumidas. Entretanto, pode a lei conferir a certa parcela de bens destinação distinta, constituindo, assim, patrimônio afetado a finalidades que não se confundem com a finalidade geral de garantia das obrigações diversas do seu titular ${ }^{667}$.

A importância da digressão aqui realizada a respeito do histórico das teorias do patrimônio torna-se mais evidente na medida em que se reconhece a possibilidade de que a

${ }^{664}$ STURZENEGGER, Luiz Carlos. A doutrina do patrimônio de afetação e o novo sistema de pagamentos brasileiro, RDBMC 11/2001: "Até recentemente o conceito de patrimônio girava em torno de uma única idéia: a de que os bens da pessoa física ou jurídica são o lastro real garantidor do cumprimento de todas as obrigaçôes assumidas indistintamente com todos os seus credores, dado o caráter vinculativo do patrimônio à personalidade jurídica do sujeito que o possui.

Boa parte dos ordenamentos jurídicos modernos segue essa doutrina, originalmente denominada de teoria subjetiva, que considera o patrimônio uma universalidade indivisível de direitos, sendo, assim, uma unidade autônoma, distinta dos elementos que a compóe."

${ }^{665}$ STURZENEGGER, Luiz Carlos. A doutrina do patrimônio de afetação e o novo sistema de pagamentos brasileiro, RDBMC 11/2001: "Contra o subjetivismo da teoria clássica e apresentando uma construção capaz de compreender o porquê da existência de tais casos excepcionais, os escritores modernos imaginaram a construção de uma outra teoria, pela qual é perfeitamente aceitável uma segregação ou divisão do patrimônio pelo encargo imposto a certos bens, que são postos, de maneira incomunicável com o restante do conjunto patrimonial, a serviço de um fim determinado."

666 STURZENEGGER, Luiz Carlos. A doutrina do patrimônio de afetação e o novo sistema de pagamentos brasileiro, RDBMC 11/2001: "A situação peculiar do patrimônio especial resulta, assim, dos fins igualmente especiais a que se encontra vinculado. Não se pode esquecer, todavia, que a unidade patrimonial somente se perde quando há um conjunto de normas legais regendo a flexibilização dessa unidade; em outras palavras, quando existe, na esfera patrimonial, uma esfera jurídica mais restrita, delimitada por critérios legalmente determinados. É a lei, portanto, e somente ela, o instrumento capaz de determinar as relações jurídicas entre os patrimônios especial e geral para a consecução dos fins objetivados."

${ }^{667}$ STURZENEGGER, Luiz Carlos. A doutrina do patrimônio de afetação e o novo sistema de pagamentos brasileiro, RDBMC 11/2001: "A construção doutrinária segundo a qual determinados bens se destacam da unidade abstrata do patrimônio geral para servir a fim determinado, limitando-se, por este modo, a ação dos credores sobre esse ou aquele patrimônio, é hoje materializada, e em alguns países já positivada, no chamado patrimônio de afetação." 


\section{•• Teoria jurídica do crédito público e operações estruturadas}

cada patrimônio de afetação seja atribuído um diferente administrador ${ }^{668}$. Isto, pois, nessa hipótese, notam-se de maneira mais evidente os contornos dos fundos de investimento como patrimônios afetados a finalidades específicas pelo seu regulamento, não se confundindo tal patrimônio com o patrimônio geral dos cotistas, tampouco com o patrimônio geral da administradora.

Argumenta-se, outrossim, que a teoria do patrimônio de afetação permitiria a "assimilação dos benefícios do instituto do trust" em ordenamentos jurídicos de origem romano-germânica, como o caso do direito brasileiro ${ }^{669}$. Daí a colocação de que os fundos de investimento seriam condomínios especiais, baseados sobre a concepção de patrimônio de afetação, cujos efeitos práticos o aproximariam do flexível instituto do trust do direito anglo-saxão ${ }^{670}$.

Os fundos especiais não se confundem com os fundos de investimentos, na medida em que os primeiros são meros destacamentos do orçamento estatal, vinculado a finalidades específicas. Trata-se, por conseguinte, de técnica legislativa de vinculação de recursos públicos a destinações precisas. Nesta ordem, os fundos especiais não são sujeito de direito destacado do seu ente instituidor. Os fundos de investimentos, por outro lado, são sujeitos de direito despersonalizados, cujo patrimônio e operações guardam autonomia em relação ao patrimônio e ações do ente estatal instituidor ${ }^{671}$.

${ }^{668}$ STURZENEGGER, Luiz Carlos. A doutrina do patrimônio de afetação e o novo sistema de pagamentos brasileiro, RDBMC 11/2001: "O patrimônio especial pode ser gerido por pessoa diversa da de seu titular ou diversa da que tem a administração do patrimônio geral. Em tal caso, se manifesta abertamente a separação dos patrimônios. Em outros casos pode administrá-los o mesmo titular de ambos os patrimônios, de forma que é confiada a ele a manutenção da separação entre as duas massas patrimoniais."

669 STURZENEGGER, Luiz Carlos. A doutrina do patrimônio de afetação e o novo sistema de pagamentos brasileiro, RDBMC 11/2001: “(...) É possível desenvolver em países com essa tradição, por exemplo, pela afetação do patrimônio, a assimilação dos benefícios do instituto do trust, de origem saxônica. A melhor expressão dessa assimilação encontra-se na doutrina que altera e expande o conceito do direito romano de negócio fiduciário, para formular a teoria moderna do fideicomisso legal."

670 STURZENEGGER, Luiz Carlos. A doutrina do patrimônio de afetação e o novo sistema de pagamentos brasileiro, $R D B M C$ 11/2001: "De outro lado, apesar de, por dificuldades dogmática e históricas, os esforços para assimilação da idéia do trust no Brasil não terem produzido os mesmos resultados alcançados em outros países de tradição romana (notadamente México e Canadá), esses esforços pelo menos deram origem ao aproveitamento, no Brasil, de alguns dos elementos do instituto anglo-americano.

É nessa linha que se encontra a estrutura dos fundos de investimento, formulada no direito brasileiro a partir da vigência da Lei de Mercado de Capitais (Lei 4.728, de 1965), notadamente aquela pertinente ao fundo de investimento imobiliário, regulado pela Lei 8.668, de 1993."

671 ZANCHIM, Kleber Luiz. Fundos especiais e projetos de infraestrutura, pp. 959-60: "Os fundos especiais são, do ponto de vista estrutural, destaques orçamentários afetados a determinado fim. Correspondem a um conjunto de recursos separado do restante do orçamento de um ente estatal. Como se trata de dinheiro, os fundos especiais são objeto de direito. Não titulam posiçôes jurídicas. Ao contrário, servem de meio para o cumprimento de certas obrigaçôes relativas a programas de governo. (...)

Dessa forma, os fundos especiais são diferentes dos fundos de investimento do mercado de capitais. Estes são sujeitos de direito com patrimônio próprio, não se confundindo com seus cotistas. O patrimônio dos cotistas são suas cotas; o do fundo, seus ativos e passivos. Os resultados positivos ou negativos da operação são apropriados pelo fundo em si, alcançando seus investidores apenas quando do rateio de ganhos ou perdas. Economicamente as cotas se valorizam ou se desvalorizam acompanhando o desem- 
A vinculação de receitas proporcionada pelos fundos especiais meramente contábeis não gera direito real de garantia a eventuais credores do Poder Público sobre os recursos arrecadados, servindo apenas como espécie de "reforço de crédito", ou seja, garantia econômica de existência de recursos, o que poderá provocar em eventuais contratantes privados a sensação de menor risco na relação jurídica e econômica travada com o Estado ${ }^{672}$.

O grande risco dessa forma de garantia, consiste justamente no fato de não permitir a execução forçada dos recursos públicos, tornando necessário o recurso ao Poder Judiciário e, consequentemente, inevitável que a execução se dê por meio do regime de precatórios previsto no artigo 100 da Constituição Federal ${ }^{673}$.

A criação de fundos especiais (ou fundos contábeis), na forma do artigo 71 da Lei n. $4.320 / 64^{674}$, muito se assemelha à ideia de vinculação de receitas. Contudo, os fundos contábeis implicam maior transparência na aplicação dos recursos, na medida em que se cria segregação orçamentária especial para a utilização dos recursos, com observância de regras contábeis próprias, visando demonstrar a arrecadação, a aplicação e os saldos dos recursos vinculados ${ }^{675}$.

penho do fundo. Juridicamente, porém, há duas relaçôes: uma entre o cotista e o fundo, outra entre este e suas contrapartes operacionais."

${ }^{672}$ NUNES, Cleucio Santos. Comentários aos arts. 71 a 74, p. 244: "Por isso os fundos especiais despontam como uma garantia de reserva de recursos públicos para aplicação na política pública que lhe dá ensejo.” Cf. também SCHIRATO, Vitor Rhein. Os sistemas de garantia nas parcerias público-privadas: "A vinculação de receitas é um mecanismo orçamentário e, conforme a estruturação no negócio, contratual. A sistemática de vinculação de receitas não permite a constituição de um direito real de garantia em favor do particular. Apenas acena com a existência de uma receita específica que servirá para garantir o integral e pontual pagamento das obrigaçóes do parceiro público nos termos do contrato de PPP celebrado.

Haverá uma obrigação (legal e, dependendo do arranjo do projeto, contratual) de o parceiro público utilizar os recursos vinculados para o pagamento dos valores devidos. Todavia, não é assegurado ao particular o direito de tomar os recursos para si e proceder à sua excussão, conforme mecanismo assegurado ao credor contemplado com direito real de garantia.” No mesmo sentido CARVALHO, André Castro. Vinculação de receitas públicas, p. 132: "Diante disso, a segunda regra é que a vinculação de receitas não funciona como garantia de autossatisfação de um débito, mas sim como certeza de que os créditos orçamentários vinculados para este fim não poderão ser tredestinados em detrimento do adimplemento da obrigação contraída. Com isso, conclui-se que a vinculação de receitas, na função de garantia (vinculação-garantia), traduz-se no comprometimento orçamentário de que os recursos deverão ser utilizados para o adimplemento da obrigação contraída, sendo vedadas a dupla vinculação e autossatisfação do débito por meio das receitas garantidas."

673 SCHIRATO, Vitor Rhein. Os sistemas de garantia nas parcerias público-privadas: "Entretanto, essa sistemática apresenta alguns riscos para o parceiro privado, pois não é mais concreta, sólida e líquida das formas de garantia em operaçōes dessa natureza. Os riscos decorrentes da inexistência de direito real de garantia são, ainda, agravados pela impossibilidade de ação de execução patrimonial direta com vistas à penhora dos recursos vinculados contra a Administração Pública, com fundamento no artigo 100 da Constituição Federal, o que dificulta ainda mais o acesso do parceiro privado aos recursos vinculados."

674 NUNES, Cleucio Santos. Comentários aos arts. 71 a 74, p. 239: "A Constituição de 1988 prescreveu no art. $165, \$ 99^{\circ}$, II que cabe à lei complementar estabelecer as condições para instituição e funcionamento de fundos. À mingua da lei complementar a que alude o dispositivo constitucional, o Supremo Tribunal Federal decidiu que a Lei n. 4.320/1964 exerce esse papel em seus arts. 71 a 74 (ADI-MC 1726/DF, rel. Min. Maurício Corrêa, j. 16.09.1998)."

675 SCHIRATO, Vitor Rhein. Os sistemas de garantia nas parcerias público-privadas: "Fundos contábeis constituem uma forma de segregação de recursos orçamentários, operada dentro do próprio orçamento 
Os fundos públicos especiais, assim como os fundos de investimento, não possuem personalidade jurídica. $\mathrm{Na}$ prática, contudo, é possível se observar autarquias que são nomeadas como "fundos", sem perderem a sua natureza de autarquia, donde decorre a sua personalidade jurídica ${ }^{676}$. Não são, porém, verdadeiros fundos públicos especiais ${ }^{677}$.

Os fundos públicos, contudo, apresentam nível de risco semelhante ao credor, em relação à simples vinculação de receitas, na medida em que o fundo apresenta-se como mera segregação contábil de recursos, não apresentando personalidade jurídica apartada da do ente instituidor, o que torna inviável a constituição de qualquer direito real de garantia sobre o seu patrimônio ${ }^{678}$.

Embora Cleucio Nunes defenda que a diferença entre fundos especiais e fundos de investimento consiste simplesmente na compulsoriedade da formação dos primeiros em relação aos últimos ${ }^{679}$, não se pode, em nossa opinião, sustentar essa visão.

Em verdade, ao contrário dos fundos de investimento, os fundos públicos não têm o seu patrimônio representado por cotas. Não há, ademais, relação fiduciária nos fundos

público. Vale dizer, por meio da instituição de um fundo orçamentário, o Poder Público estabelece que determinadas receitas orçamentárias serão segregadas das demais e destinadas a finalidades específicas. Constituem forma de exceção ao princípio da unicidade de tesouraria, insculpido no artigo 56 da Lei n. 4.320/64, na medida em que determinam que parcela das receitas públicas especialmente designadas terá como finalidade específica a cobertura de uma certa e especificada despesa pública."

${ }^{676}$ NUNES, Cleucio Santos. Op. cit., p. 244: "Não é possível esquecer, no entanto, que certas entidades autárquicas recebem a denominação generalizante de fundo. Trata-se de mera denominação. Em verdade, tais entes são autarquias e o conceito de autonomia financeira deve ser aplicado integralmente para esse tipo de ente público."

677 NUNES, Cleucio Santos. Op. cit., p. 240: "Por meio desse conceito, não há dúvidas de que o 'fundo público' é aplicação de recursos em determinado fim. Daí porque perdem corpo especulações a respeito da natureza jurídica dos fundos públicos, as quais confundem 'fundos especiais' (públicos) com entidades, tentando emprestar àqueles personalidade jurídica que, na essência é irrelevante para compreender o que são 'fundos'."

678 SCHIRATO, Vitor Rhein. Os sistemas de garantia nas parcerias público-privadas: "Vistas as questôes constitutivas dos fundos, é importante mencionar que esses não são oponíveis a terceiros, sendo vinculantes apenas com relação à Administração Pública que os houver instituído. É dizer, não é válido qualquer pleito em face do fundo orçamentário, nem tampouco a tentativa de execução, penhora, sequestro, ou outro meio de tomada, dos recursos neles contidos. Tais fundos são simples reservas orçamentárias de recursos.

Em vista disso, vislumbramos, com relação aos fundos contábeis, risco semelhante ao vislumbrado com relação à vinculação de receitas. É bem verdade que os fundos contábeis apresentam um certo nível de segurança ao particular em razão da existência de reserva de recursos para a realização dos pagamentos devidos (é o denominado mecanismo de cash trap em operaçóes similares).

Contudo, a inexistência de direito real sobre os recursos contidos no fundo especial apresenta risco ao particular, que dependerá (i) da manu tenção da existência do fundo durante toda a vigência do contrato de PPP (risco político) e (ii) da efetiva existência de recursos no fundo (risco de realização das receitas alocadas ao fundo) e (iii) da efetiva utilização, pela Administração Pública, dos recursos existentes no fundo para o saldo de suas obrigações (novamente, risco político)."

${ }^{679}$ NUNES, Cleucio Santos. Comentários aos arts. 71 a 74, p. 241: "O que distingue o fundo de investimento (de natureza privada) do fundo especial (de natureza pública) é simplesmente a compulsoriedade da formação do capital e a finalidade." 
públicos, sendo o próprio Poder Público titular direto dos recursos que integram o fundo, agindo diretamente em seu próprio nome e não por meio de administrador. Os fundos contábeis não se confundem com fundos de investimento, criados na forma da legislação do mercado de capitais, portanto. Estes últimos constituem patrimônio separado do patrimônio do seu instituidor, muito embora não detenham personalidade jurídica própria. Assim, a propriedade do ente público instituidor do fundo de investimentos restringe-se às cotas deste fundo, não detendo o ente público titularidade sobre os bens que integram o patrimônio do fundo de investimentos ${ }^{680}$.

Também não é possível aos fundos públicos, meras vinculações de receita e de saldos financeiros que são ${ }^{681}$, terem em seu patrimônio outros bens além de moeda corrente, créditos em instituição financeira lastreados em contrato de conta-corrente, ou quotas de fundos de investimento para aplicação de suas disponibilidades, na forma do artigo 43 da LRF.

Os fundos especiais devem ainda integrar a lei orçamentária anual e, assim, a utilização dos seus recursos deve estar autorizada por crédito orçamentário devidamente aprovado pelo Poder Legislativo ${ }^{682}$. O mesmo não ocorre no caso dos fundos de investimento, ainda que públicos, sendo impensável a necessidade de se prever autorização orçamentária específica, por exemplo, para a aquisição de tal ou qual título público por fundo de investimentos de renda fixa administrado por instituição financeira, no interesse da preservação do valor real das disponibilidades financeiras do Poder Público. Assim, de forma semelhante ao que ocorre com as empresas estatais, a autorização para a aplicação dos recursos de fundo de investimentos público decorre da adequação dessa aplicação à finalidade da sua criação, na forma do seu regulamento.

A criação de fundos públicos especiais, do ponto de vista das finanças públicas, deve ser muito bem avaliada a cada caso, tendo em vista os custos de manutenção de tais fundos e as obrigações acessórias a eles vinculadas. Ademais, a vinculação de receitas públicas a fundos específicos torna a execução orçamentária menos flexível, contribuindo para um maior risco financeiro em situação de redução da arrecadação, além de representar potencial enfraquecimento do debate democrático que anualmente deveria se realizar por conta da tramitação da proposta de lei orçamentária ${ }^{683}$.

680 SCHIRATO, Vitor Rhein. Op. cit.: "No que concerne à adoção de fundos garantidores, é importante mencionar que esses não se confundem com os fundos contábeis analisados no item 2.2 acima, posto que os fundos mencionados no inciso $\mathrm{V}$ do artigo $8^{\circ}$ da Lei n. 11.079/04 são fundos constituídos com natureza de fundos de investimento (com características sui generis, como se verá no item subsequente com relação ao FGP) e patrimônio próprio e não simplesmente reservas contábeis denominadas fundos."

${ }^{681}$ NUNES, Cleucio Santos. Comentários aos arts. 71 a 74, p. 242: "O conceito de fundo, portanto, emerge da própria noção de orçamento público, na medida que o 'fundo' serve para reunir receitas afetadas e dirigidas para determinadas finalidades. Somente a fixação das receitas e despesas em um orçamento é capaz de ensejar a instrumentalização de receitas públicas em torno de um fim específico."

${ }^{682}$ NUNES, Cleucio Santos. Comentários aos arts. 71 a 74, p. 243: "A Constituição da República é taxativa nesse sentido, ao prescrever que a lei orçamentária anual compreenderá, além do orçamento fiscal dos poderes da República, o dos fundos, órgãos e entidades da administração direta e indireta (art. 165, $\left.\$ 5^{\circ}, \mathrm{I}, \mathrm{da} \mathrm{CF} / 1988\right) . ”$

683 NUNES, Cleucio Santos. Op. cit., p. 250: "Primeiramente, é conveniente avaliar se os cursos com a criação e a manutenção do fundo e dos instrumentos para a sua execução não serão mais elevados do 


\section{•• Teoria jurídica do crédito público e operações estruturadas}

A utilização de recursos do fundo fica submetida às regras gerais de finanças públicas e orçamentárias, entre as quais se destacam as normas relativas à responsabilidade fiscal, sobretudo o atingimento de metas de superávit fiscal e nominal, na forma definida pelos anexos da Lei de Diretrizes Orçamentárias anualmente aprovada ${ }^{684}$. Isto, pois, vincular a receita a uma determinada finalidade não implica transformar tal vinculação em regra de despesa obrigatória ${ }^{685}$.

Ao contrário do previsto pela Lei n. 4.320/1964 para os fundos especiais, os fundos de investimento públicos não precisam de autorização legal para serem criados pelo simples fato de não serem criados por ato de vontade do Poder Público, mas por ato de vontade do seu administrador, que aprova o seu regulamento, conforme determina para os fundos de investimento em geral a Instrução CVM n. 555/2016, no seu artigo $6^{\text {o686 }}$.

Ainda assim, a desnecessidade de autorização legal para constituição de fundos de investimento públicos, entendidos como aqueles cujos cotistas únicos são pessoas de direito público, não elide a necessidade de autorização legal orçamentária para a realização da despesa pública ligada à subscrição das cotas do referido fundo de investimentos criado por deliberação do seu administrador. Também não fica afastada a obrigatoriedade de atenção às condiçôes do artigo 17 da Lei n. 8.666/1993, para o aporte de bens e direitos do ente público em fundos de investimento, destacando-se a necessidade de autorização legal específica para o aporte de bens imóveis. Contudo, verifica-se como inaplicável a exigência, neste caso, de realização de licitação por ser incompatível com a natureza do aporte ${ }^{687}$.

ponto de vista da economicidade, do que prever a execução das despesas pela via orçamentária comum. Cada fundo que se cria é sinônimo de elevação de gastos com a máquina administrativa, por meio da criação de uma unidade gestora, ou o aumento de gastos operacionais com o sistema contábil de execução do fundo.

O número de fundos existentes pode ser também o sintoma de enfraquecimento da lei orçamentária, que não consegue atender às demandas dos setores públicos, entregando ao poder Executivo liberdade de gestão orçamentária na área de atuação do fundo. Assim, bastam se prever recursos orçamentários para o fundo e a presunção é a de que o interesse público está sendo satisfatoriamente atendido.”

684 NUNES, Cleucio Santos. Op. cit., p. 252: "Fixadas essas premissas, logo se percebe que os fundos públicos não podem ficar dissociados das metas fiscais estabelecidas pela política econômica e nas leis de diretrizes orçamentárias.” E na página 253: “Com esses fundamentos é possível asseverar a viabilidade jurídica de contingenciamento de receitas dos fundos públicos nas hipóteses de ameaças de vulneração das metas."

685 NUNES, Cleucio Santos. Op. cit., p. 255: “(...) Os arts. 71 e 72 da Lei n. 4.320/1964, apenas asseguram a vinculação das receitas do fundo à sua respectiva conta e finalidade, mas não a necessária execução de despesas previstas na lei orçamentária com as receitas do fundo.”

686 Art. 60 O fundo será constituído por deliberação de um administrador a quem incumbe aprovar, no mesmo ato, o regulamento do fundo.

687 MEIRELLES, Hely Lopes. Direito municipal brasileiro, p. 332: “Alienação é toda transferência de propriedade, remunerada ou gratuita, sob a forma de venda, doação, dação em pagamento, permuta, investidura, legitimação de posse ou concessão de domínio. Qualquer dessas formas de alienação pode ser usada pelo Município, desde que satisfaça as exigências administrativas para o contrato alienador e atenda aos requisitos específicos do instituto utilizado. Em princípio, toda alienação de bem público depende de lei autorizadora, de licitação (Lei 8.666/1993, art. 17, I, e II) e de avaliação da coisa a ser alienada; mas casos há de inexigibilidade dessas formalidades, por incompatíveis com a própria natureza do contrato. (...)". 
Conforme argumentado, não se pode confundir os fundos de investimentos com fundos públicos especiais. Os primeiros detêm a natureza jurídica de condomínio especial, constituindo verdadeiro patrimônio de afetação que se aproxima da ideia de propriedade fiduciária existente nos trusts do direito anglo-saxão. Por outro lado, os fundos especiais são meras vinculações legais de receitas, com contabilização específica.

Diante desse quadro jurídico-normativo, a questão que se coloca, portanto, seria a de identificar a natureza jurídica dos fundos de investimentos públicos e, consequentemente, o regime jurídico a eles aplicável.

Antes de mais nada, convém definir o que se entende neste trabalho por fundos de investimentos públicos. Tais fundos nada mais são do que fundos de investimentos cujas cotas são titularizadas por pessoas jurídicas de direito público. Sendo assim, as cotas de referidos fundos são consideradas bens públicos móveis, sujeitando-se às regras de alienação próprias dos bens públicos, na forma do artigo 17, II ${ }^{688}$, da Lei n. 8.666/93.

Com relação a este ponto específico, interessante questão consiste em avaliar a possibilidade de aplicação por analogia do artigo 17, II, $c$, em caso dos chamados exchangetraded funds (ETFS). Os ETFs são fundos de investimento cujas cotas são admitidas à negociação em bolsas de valores, assim como as açôes de empresas. Tais fundos vêm se popularizando como uma forma de aplicação de longo prazo em renda variável, por suas menores taxas de administração, maior liquidez e possíveis eficiências tributárias ${ }^{689}$.

${ }^{688}$ Art. 17. A alienação de bens da Administração Pública, subordinada à existência de interesse público devidamente justificado, será precedida de avaliação e obedecerá às seguintes normas: (...) II - quando móveis, dependerá de avaliação prévia e de licitação, dispensada esta nos seguintes casos: a) doação, permitida exclusivamente para fins e uso de interesse social, após avaliação de sua oportunidade e conveniência sócio-econômica, relativamente à escolha de outra forma de alienação; b) permuta, permitida exclusivamente entre órgãos ou entidades da Administração Pública; c) venda de ações, que poderão ser negociadas em bolsa, observada a legislação específica; d) venda de títulos, na forma da legislação pertinente; e) venda de bens produzidos ou comercializados por órgãos ou entidades da Administração Pública, em virtude de suas finalidades; f) venda de materiais e equipamentos para outros órgãos ou entidades da Administração Pública, sem utilização previsível por quem deles dispōe.

689 BODIE, Zvi; KANE, Alex; MARCUS, Alan. Investimentos, pp. 91-94: "Os fundos negociados em bolsa (exchange-traded funds - ETFs) são uma ramificação dos fundos mútuos criados em 1993 que permitem que os investidores negociem carteiras de índice do mesmo modo que negociam ações. (...) Os ETFs oferecem várias vantagens em relação aos fundos mútuos convencionais. Primeiro, como já ressaltamos, o NAV do fundo mútuo é cotado - e, portanto, os investidores podem comprar ou vender suas ações no fundo - uma única vez ao dia. Em contraposição, os ETFs são negociados constantemente. Além disso, assim como outras ações, mas diferentemente dos fundos mútuos, os ETFs podem ser vendidos a descoberto ou comprados na margem.

Adicionalmente, os ETFs oferecem uma possível vantagem tributária em relação aos fundos mútuos. Quando um grande número de investidores de fundos mútuos resgata suas ações, o fundo precisa vender títulos para atender aos resgates. A venda pode gerar impostos sobre os ganhos de capital, que são repassados para os acionistas remanescentes e devem ser pagos por eles. Em contrapartida, quando os pequenos investidores desejam resgatar sua posição em um ETF, eles simplesmente vendem suas ações a outros negociadores, e o fundo não precisa vender nenhuma parte da carteira subjacente. Os grandes investidores podem trocar suas açôes do ETF pela carteira subjacente; essa forma de resgate também evita incidência de impostos. 


\section{•• Teoria jurídica do crédito público e operações estruturadas}

Em nosso entendimento, embora o artigo 17, II, c, da Lei n. 8.666/93 textualmente se refira apenas às ações como sujeitas à alienação em bolsa, entendemos que o procedimento de oferta de venda em bolsa assegura ao Poder Público o mesmo nível de transparência e isonomia que seriam obtidos por meio das modalidades de licitação previstas na Lei n. 8.666/93. Isto ocorre, pois, as transações ocorridas em bolsa se sujeitam à regulação específica da Lei n. 6.385/76, às regras emanadas da CVM e à autorregulação decorrente de normas de operação estipuladas pelas próprias bolsas de valores, sempre no interesse de proteção da poupança pública e da redução de assimetrias de informação. Assim, conclui-se pela possibilidade de alienação de outros valores mobiliários detidos pelo Poder Público na forma da legislação específica relativa ao mercado de capitais, o que, evidentemente, inclui cotas de ETFs.

É relevante observar que no caso dos fundos de investimento abertos, o resgate de cotas não se confunde com a sua alienação ao administrador, sendo evento próprio deste tipo de veículo de investimento. Portanto, não há que se falar em (in)observância de normas relativas à alienação de bens públicos no caso de resgate de cotas de fundo de investimento aberto ${ }^{690}$. Também não se poderá dizer, em respeito às normas orçamentárias e financeiras aplicáveis - sobretudo a Lei n. 4.320/1964 e a Lei Complementar n. 101/2000 - que o resgate de cotas de fundo de investimento aberto gere o reconhecimento de uma nova receita pública, devendo-se tão somente, neste evento, reconhecer a ocorrência de um fato patrimonial permutativo, especialmente quando a valorização das cotas já esteja adequadamente refletida no patrimônio do ente público delas titular.

Outro tema relevante consiste em saber se é necessária autorização legal para a constituição de fundo de investimento público, dada a exigência legal que existe para a constituição de fundos públicos especiais, conforme já tratado acima neste trabalho.

Ainda que não se possa confundir fundos públicos especiais e fundos de investimento públicos, deve-se atentar para o fato de que ambos requerem autorização legal para a aplicação de recursos públicos. No caso dos fundos de investimento, naturalmente, a autorização legal não é requisito para a constituição do fundo, dado que esta ocorre por ato de vontade do seu administrador ${ }^{691}$. Por outro lado, a autorização legal se faz necessária para a aplicação de recursos públicos em fundo de investimento, por meio da aquisição de cotas.

Os ETFs são também mais baratos do que os fundos mútuos. Os investidores que compram ETFs o fazem por meio de corretores, e não comprando diretamente do fundo. Dessa forma, o fundo poupa o custo de negociar diretamente com os pequenos investidores. Essa redução de despesas traduz-se em menores taxas de administração."

690 CORDONIZ, Gabriela; PATELLA, Laura (Coord.). Comentários à Lei do Mercado de Capitais - Lei n. 6.385/76, pp. 65-6: "Desta forma, considera-se aberto o fundo em que o cotista não pode ceder a sua cota, mas pode solicitar o resgate de seu investimento a qualquer momento. Por outro lado, considera-se fechado o fundo em que o cotista pode resgatar suas cotas apenas no término do fundo, mas, entretanto, pode cedê-las, sendo estas passíveis de negociação em mercado secundário.”

691 CORDONIZ, Gabriela; PATELLA, Laura (Coord.). Comentários à Lei do Mercado de Capitais - Lei n. 6.385/76, p. 66: "Os fundos de investimento são constituídos por deliberação de seu administrador (figura prevista no art. 23 da Lei n. 6.385/76, e regulado pela Instrução CVM n. 306, de 5 de maio de 1999), responsável pela administração e gestão do patrimônio comum dos cotistas. Ao administrador é facultado terceirizar certos serviços prestados ao fundo de investimento, como a gestão da carteira do fundo, que pode ser realizada por pessoa física ou jurídica credenciada junto à CVM como administrador de carteira de valores mobiliários." 
No caso dos fundos de investimento públicos voltados à aplicação de disponibilidades financeiras do Poder Público, com a finalidade exclusiva de manter o seu valor real e evitar os custos financeiros decorrentes da manutenção de recursos em depósitos bancários não remunerados, a autorização legal é genérica e contida no artigo $35, \$ 2^{\circ 692}$, e no artigo $43^{693}$ da Lei Complementar n. 101/2000, assim como no artigo $164, \$ 3^{\circ}$, da Constituição Federal ${ }^{694}$.

Deve-se concluir dessa maneira, em virtude de os dispositivos tratados exigirem que a aplicação dos recursos se dê por meio de instituição financeira oficial ${ }^{695}$, ao mesmo tempo em que se permite expressamente a aplicação de disponibilidades em títulos públicos emitidos pela União Federal.

Ora, um dos meios de se assegurar a aplicação das disponibilidades financeiras dos entes públicos em títulos públicos por meio de instituição financeira oficial seria justamente a aplicação em cotas de fundo de investimento exclusivo, criado e administrado por instituição financeira oficial, cujo regulamento preveja a aplicação exclusiva em títulos públicos de emissão da União. Em nosso entendimento, neste caso específico, os mencionados dispositivos legais e da Constituição supririam autorização específica para aplicação de recursos em fundo de investimentos. Nesta situação, inclusive, a aplicação de recursos não representaria execução orçamentária de despesa, mas mero fato patrimonial permutativo, com reflexos unicamente extraorçamentários.

Outra deve ser a conclusão em caso de aplicação de recursos públicos por meio da aquisição de cotas de fundos de investimento. Tratando-se da aplicação de recursos públicos para a aquisição de valores mobiliários que não representam mera aplicação de disponibilidades financeiras para preservação do seu valor real, deve preceder tal aplicação autorização legal, contida em lei orçamentária anual, que deverá prever o limite de créditos orçamentários para a ação específica.

Por outro lado, não é necessária autorização legal específica para a criação do fundo de investimentos, ou autorização legal em lei apartada à lei orçamentária anual, posto que os fundos de investimento públicos não se confundem com os chamados fundos públicos especiais, não havendo imposição de autorização de criação por lei específica para os fundos de investimento como há para os fundos especiais.

Assim, entende-se como possível a aplicação de recursos públicos em finalidades estatais por meio de fundos de investimento público, desde que previamente autorizada a

${ }^{692}$ Art. 35. É vedada a realização de operação de crédito entre um ente da Federação, diretamente ou por intermédio de fundo, autarquia, fundação ou empresa estatal dependente, e outro, inclusive suas entidades da administração indireta, ainda que sob a forma de novação, refinanciamento ou postergação de dívida contraída anteriormente. (...) $\$ 2^{\circ} \mathrm{O}$ disposto no caput não impede Estados e Municípios de comprar títulos da dívida da União como aplicação de suas disponibilidades.

${ }^{693}$ Art. 43. As disponibilidades de caixa dos entes da Federação serão depositadas conforme estabelece o $\$$ $3^{\circ}$ do art. 164 da Constituição.

${ }^{694}$ Art. 164 (...) $₫ 3^{\circ}$ As disponibilidades de caixa da União serão depositadas no banco central; as dos Estados, do Distrito Federal, dos Municípios e dos órgãos ou entidades do Poder Público e das empresas por ele controladas, em instituições financeiras oficiais, ressalvados os casos previstos em lei.

${ }^{695} \mathrm{Ou}$ seja, instituição financeira pública. 


\section{•• Teoria jurídica do crédito público e operações estruturadas}

aplicação pela abertura de crédito orçamentário. A utilização do veículo dos fundos de investimento públicos pode ser interessante mecanismo alternativo à criação de empresas estatais, por exemplo, sobretudo nas atividades estatais de fomento e de intervenção no domínio econômico, sendo os Fundos de Investimentos em Parcerias (FIPs) um instrumento possível de ser utilizado nesse sentido.

Por fim, observa-se que também na função de mecanismo garantidor os fundos de investimento público podem servir de alternativa às empresas estatais que, conforme apresentado anteriormente, são comumente utilizadas com essa finalidade. Assim como o patrimônio das empresas estatais, o patrimônio dos fundos garantidores - que no caso das PPPs são criados com base no artigo $8^{\circ}$ da Lei n. 11.079/2004 - não se sujeita à execução por regime de precatórios, por não se confundir com o patrimônio do ente instituidor, ao mesmo tempo em que carecem os fundos de investimento de personalidade jurídica, seja de direito público seja de direito privado ${ }^{696}$.

Com relação exclusivamente ao Fundo Garantidor de Parcerias, posteriormente incorporado ao Fundo Garantidor de Infraestrutura criado com base no artigo 32 c/c artigo 58 da Lei n. 12.712, de 30 de agosto de 2012, Vitor Rhein Schirato entende não ser possível aos entes estaduais e municipais a criação de fundos de investimento garantidores, na forma do FGP criado em âmbito federal, por se tratar de matéria de competência exclusiva da União Federal (direito comercial) ${ }^{697}$.

O autor sustenta o seu entendimento sobre a ideia de não se tratar o FGP de fundo de investimentos convencional, criado conforme as regras gerais para fundos de investimento editadas pela CVM, isto pois o FGP garante ele próprio os contratos públicos, não se tratando de garantia da União por meio de penhor ou cessão fiduciária de cotas do Fundo, o que não estaria interditado aos estados e municípios ${ }^{698}$. Tendemos a concordar com tal argumentação, ressaltando, porém, que esse entendimento não obsta a prestação de garantia por estados e municípios por meio da cessão fiduciária ou do penhor de cotas de fundos de investimento.

696 SCHIRATO, Vitor Rhein. Op. cit.: "Ademais, por serem entidades de Direito privado, as empresas estatais ou fundos garantidores não se sujeitam ao regime de precatórios consagrado no artigo 100 da Constituição Federal, recaindo qualquer execução diretamente contra seus respectivos patrimônios. Esse expediente facilita consideravelmente a aceitabilidade do sistema de garantias constituídas por empresa ou fundo, na medida em que aumentam a certeza de recebimento dos recursos."

697 SCHIRATO, Vitor Rhein. Op. cit.: "Muito embora possa haver certa controvérsia, entendemos ser clara a inclusão da matéria de fundos de investimento no campo do Direito Comercial, visto que se trata de tema afeto à realização de operações financeiras comerciais. Destarte, não poderiam Estados, Distrito Federal e Municípios entrar em campo de competência privativa da União Federal e criar fundo de investimento sui generis, com regime próprio, tal como fez a Lei n. 11.079/04 com relação ao FGP.”

698 SCHIRATO, Vitor Rhein. Op. cit.: "Sendo assim, entendemos que, de lege lata, não é possível a constituição, por Estados, Distrito Federal e Municípios, de fundo de investimento para a garantia de projetos de PPP, em modelo semelhante ao adotado pela União Federal, com relação ao FGP. No que concerne ao inciso V do artigo $8^{\circ}$ da Lei n. 11.079/04, podem Estados, Distrito Federal e Municípios optar por constituir empresa estatal garantidora, ou uma das modalidades de fundo de investimento atualmente existentes, sendo que no último caso a garantia seria representada pelas quotas do fundo e não pelo patrimônio do fundo, tal como ocorre com o FGP.” 
Nota-se, portanto, que os fundos de investimento públicos são instrumento alternativo à disposição do Estado para o atingimento de seus objetivos e para a formatação de operaçôes estruturadas de diversas naturezas. É preciso, porém, que sejam observadas algumas condiçôes, tais como as devidas autorizações orçamentárias para a aplicação de recursos em tais fundos, dado o fato de que os bens de tais fundos, ao contrário dos bens públicos, são plenamente penhoráveis. Ademais, os fundos de investimento público demandam especial atenção do ponto de vista fiscal, considerando-se o fato de que os cotistas do fundo respondem pelo patrimônio líquido negativo deste, conforme determina o artigo 15 da Instrução CVM n. 555/2014699.

Desta forma, verifica-se que os fundos de investimentos podem ser empregados pelo Estado como instrumento de mobilização de capitais para o seu próprio desenvolvimento. Assim como ocorre com as empresas estatais, contudo, os fundos de investimento podem originar passivos e contingências fiscais ao Estado, bem como servir de meio de alavancagem dos recursos das gerações presentes, comprometendo recursos públicos para o futuro. Esse fato reforça a necessidade de transparência na realização dessas operações e a necessidade de uma sólida dogmática jurídica sobre o tema, de maneira a conferir segurança às operaçôes e resguardar os interesses envolvidos.

\subsubsection{Contratos built to suit e esquemas sell and lease back}

Passamos no presente momento à análise de duas outras espécies de operações estruturadas que, ao contrário das demais operações citadas neste capítulo, não têm sido utilizadas com a mesma frequência pelos entes públicos, embora possam apresentar interessantes vantagens do ponto de vista do atendimento das necessidades operacionais desses entes, com possíveis impactos, porém, sobre a sua situação fiscal de médio e longo prazo. As operações a serem analisadas são, de um lado, os contratos chamados pela doutrina como built-to-suit (BtS) e, de outro, os chamados arrendamentos mercantis, ou leasings.

$\mathrm{O} \mathrm{BtS}$ - também conhecido por "locação por encomenda" - é uma espécie de contrato bastante frequente em empreendimentos comerciais e industriais e consiste na combinação dos contratos de empreitada e de aluguel, podendo ainda ser combinado com um contrato de prestação de assessoria imobiliária, para a prospecção de imóveis para a unidade que será instalada. Trata-se de um contrato, via de regra, de longo prazo, por meio do qual o investimento inicial com a obra, realizado pelo investidor via contrato de empreitada, é amortizado com o recebimento do aluguel ajustado durante todo o período de vigência do contrato. Do ponto de vista do locador, o BtS proporciona a colocação à sua disposição de imóvel adaptado ou construído conforme as suas necessidades e especificaçôes, sem a necessidade de adiantar qualquer capital para tanto ${ }^{700}$.

${ }^{699}$ Art. 15. Os cotistas respondem por eventual patrimônio líquido negativo do fundo, sem prejuízo da responsabilidade do administrador e do gestor em caso de inobservância da política de investimento ou dos limites de concentração previstos no regulamento e nesta Instrução.

700 BENEMOND, Fernanda Henneberg. Contratos built to suit, p. 12: “(...) se trata de um negócio jurídico no qual uma das partes contrata a construção ou reforma substancial de um imóvel, de acordo com as suas necessidades, e o recebe para uso e fruição, mediante o pagamento de determinada remuneração. Este tipo de negócio é destinado a construçôes ou reformas com finalidade comercial ou industrial." 
$\mathrm{O} \mathrm{BtS}$ envolve via de regra três agentes diferentes: o contratante, o investidor e o empreiteiro, sendo que as duas últimas figuras podem, em alguns casos, se confundir. $\mathrm{O}$ contratante do BtS é o sujeito interessado no imóvel, o qual contrata o investidor para prospectar opçôes de imóveis e providenciar as obras de engenharia civil necessárias. $\mathrm{O}$ empreiteiro, por sua vez, é contratado pelo investidor para a realização das obras, sendo que este remunera o empreiteiro normalmente a partir de recursos levantados no mercado financeiro ou de capitais ${ }^{701}$. Com os recursos dos aluguéis que o contratante paga ao investidor pelo uso bem e amortização dos investimentos, finalmente, este faz o pagamento dos seus credores pelos recursos originalmente levantados e retira o seu lucro na operação ${ }^{702}$.

Do ponto de vista econômico e comercial, o buit to suit apresenta uma série de vantagens em relação a alternativas disponíveis, tais como a aquisição de um imóvel seguida da contratação de uma empreitada ${ }^{703}$, podendo ainda ser consideravelmente vantajoso em

701 O financiamento dos investimentos em um buit to suit podem ser favorecidos pela securitização dos créditos imobiliários decorrentes da assinatura do contrato, o que é permitido pelo regime fiduciário que pode ser instituído com base no artigo $8^{\circ}$ da Lei n. 9.514/1997. BENEMOND, Fernanda Henneberg. Op. cit., p. 48: "A securitização propicia, fundamentalmente, do ponto de vista do tomador de recursos, o acesso a uma fonte alternativa de financiamento, com redução de custos, seja por via direta, mediante diminuição da taxa de juros, ou por via indireta, com o encurtamento dos prazos de retorno dos ativos imobilizados, por meio de títulos de dívida, e, do ponto de vista dos ativos imobilizados, por meio de títulos de dívida, e, do ponto de vista do investidor, pode viabilizar o objetivo de dispor de uma modalidade de investimento que pode oferecer vantagens, comparativamente com outros papéis do mercado, em razão da maior rentabilidade e maior segurança, pois a redução de riscos, ou sua relativa eliminação, é um dos propósitos fundamentais do processo de securitização.”

702 BENEMOND, Fernanda Henneberg. Op. cit., p. 20: "Assim, em vista dos argumentos acima, entendemos que seria mais apropriado afirmar que o built to suit consiste em um modelo de negócio jurídico no qual a parte interessada em ocupar um imóvel para o desenvolvimento de uma atividade (contratante) contrata com um empreendedor: (i) a construção, pelo próprio empreendedor ou por terceiros, de um empreendimento (edificação) em um determinado terreno (imóvel) e/ou a sua reforma substancial, de forma a atender as especificações e os interesses da contratante; e, após o término da construção ou reforma substancial, (ii) a cessão do uso e fruição (locação) do terreno com o empreendimento, por um valor que permita ao empreendedor remunerar a quantia investida na execução da obra, bem como o período de uso e fruição do imóvel, de modo a lhe proporcionar certa margem de lucro. Normalmente, estes contratos são celebrados por prazo determinado."

703 VALENÇA, Marcelo José Lomba. Built to suit - operação de crédito imobiliário estruturada: "Através do Modelo Built to suit (i) o empresário moderniza suas instalações, melhora seus índices de liquidez, e gera despesa operacional dedutível; (ii) o empreendedor imobiliário comercializa os projetos antes deles serem desenvolvidos; e (iii) o Agente Financeiro concede crédito garantido com recursos próprios e/ou de terceiros, com diferentes possibilidades de amortização e não necessariamente vinculados a qualquer sistema de financiamento imobiliário disponível."; BENEMOND, Fernanda Henneberg. Op. cit., pp. 12-3: "Dentre suas vantagens, podemos mencionar as seguintes: (i) a contratante (também chamada de 'usuária' ou 'locatária') moderniza suas instalaçôes, melhora seus índices de liquidez e contabiliza a remuneração paga ao empreendedor como despesa operacional, permitindo uma redução de sua carga tributária, (ii) o empreendedor (também chamado de 'locador' ou 'investidor') comercializa os projetos antes de seu desenvolvimento; (iii) o empreendedor capta recursos a juros menores do que aqueles cobrados por instituições financeiras, por meio da securitização dos créditos advindos do built to suit; e, (iv) o público investidor, adquirindo os valores mobiliários emitidos em razão da securitização dos créditos do built to suit, recebe, muitas vezes, uma remuneração mais elevada do que aquelas oferecidas nas tradicionais aplicações financeiras.” 
caso de equipamentos públicos, que normalmente demandam condições específicas de usabilidade, demandando intervençôes no imóvel cujo contrato convencional de aluguel normalmente não são suficientemente seguros, do ponto de vista do asseguramento do retorno do capital investido pelo locador privado, para permitir a sua execução ${ }^{704}$.

Do ponto de vista do presente trabalho, a característica mais relevante do $\mathrm{BtS}$ consiste no fato de que este contrato permite a diluição do investimento no tempo, evitando a necessidade de investir integralmente os recursos necessários à aquisição e à empreitada antes do início da fruição dos benefícios da nova infraestrutura ${ }^{705}$. Por essa exata razão, a remuneração paga pelo contratante no $\mathrm{Bt} S$ não se resume a um aluguel, isto é, a remunerar a utilização de um bem alheio, mas também a remunerar a empreitada e o custo financeiro suportado pela contraparte que antecipa os investimentos e coloca à disposição do contratante o imóvel segundo suas especificações ${ }^{706}$.

Essa característica é relevante, pois, do ponto de vista econômico, a operação se assemelharia a um financiamento realizado por meio do investidor, uma vez que este se socorre do mercado financeiro e de capitais para colocar à disposição, no nosso caso, do ente público o imóvel conforme as suas especificaçôes. De outro lado, isso gerará para o Estado o compromisso de pagar os aluguéis convencionados até o prazo final do contrato, o qual usualmente excede o ano financeiro e consequentemente a validade dos créditos orçamentários. A semelhança com uma operação de financiamento fica ainda mais evidente quando se observa que as operações de $\mathrm{BtS}$ são normalmente alavancadas pelo investidor a partir da securitização dos créditos decorrentes dos futuros aluguéis ${ }^{707}$.

${ }^{704}$ BENEMOND, Fernanda Henneberg. Op. cit., p. 17: "O built to suit também é vantajoso para hospitais, laboratórios, escolas, depósitos e outras atividades que necessitam de imóvel com estrutura especial, uma vez que cabe à contratante especificar as condições e detalhes do imóvel a ser construído e, posteriormente, cedido para uso e fruição."

705 BENEMOND, Fernanda Henneberg. Op. cit., p. 22: "Por outro lado, caso a contratante opte por adquirir um terreno e proceder à construção da edificação por meio de uma empreitada normal, terá, necessariamente, um desembolso inicial muito grande, o que aumentaria exponencialmente se esta mesma empresa tivesse que obter um financiamento para consecução desse objetivo. Assim, do ponto de vista financeiro, há uma efetiva diluição do custo quando se compara o built to suit com a hipótese de aquisição do terreno e posterior construção, especialmente se a contratante não possuir disponibilidade imediata de recursos para arcar com o investimento, o que demandaria a obtenção de financiamento, com custos inerentes a isso."

706 BENEMOND, Fernanda Henneberg. Op. cit., p. 29: "No buit to suit, a remuneração pactuada é resultado de uma equação que leva em consideração (i) o retorno dos investimentos efetivados com a eventual aquisição do terreno e com a construção da edificação e/ou sua reforma substancial, conforme o interesse da contratante (payback); (ii) a remuneração pelo uso e fruição do imóvel pela contratante durante determinado prazo; e, (iii) a margem de lucro do empreendedor."

707 SCAVONE JÚNIOR, Luiz Antonio. Direito imobiliário: teoria e prática, pp. 1166-7: "É comum, neste tipo de contrato, que, além do contratante (o locatário, que rece o imóvel encomendado) e do contratado (o locador, que providencia a construção e cede o imóvel), esteja presente um terceiro, ou seja, uma companhia securitizadora de recebíveis.

Em outras palavras, o contratado (locador) constrói ou manda construir, cede o seu imóvel ao contratante (locatário) mediante pagamentos mensais e transfere os seus créditos para uma companhia securitizadora, recebendo antecipadamente, o valor estabelecido no contrato. 


\section{•• Teoria jurídica do crédito público e operações estruturadas}

O compromisso do Estado no $\mathrm{BtS}$ acaba por se tornar um compromisso com repercussões sobre períodos futuros, por conta da possibilidade de renúncia no contrato do direito à proposição de ação revisional do valor do aluguel e também por conta da possibilidade de fixação de multa equivalente à soma dos valores dos aluguéis a receber até o termo final da locação no caso de denúncia antecipada do vínculo locatício pelo locatário, conforme expressamente prevê o art. 54-A da Lei n. 8.245/1991 (Lei do Inquilinato - LI).

Assim, o primeiro desafio a ser analisado consiste na possibilidade de contratação do $\mathrm{BtS}$ por entes públicos, considerando a limitação de prazo para os contratos administrativos prevista no art. 57, da Lei n. 8.666/1993 e o fato de que se trata de contrato assinado geralmente por prazos mais longos, de maneira a permitir a amortização dos investimentos realizados no imóvel.

De nossa parte, entendemos como possível a contratação, considerando-se o art. 62, $\$ 3^{\circ}$, I, da Lei n. 8.666/1993, que expressamente reconhece que os contratos de locação são regidos predominantemente por normas de direito privado, aplicando-se apenas residualmente e no que couber, as normas gerais decorrentes daquela lei.

De toda forma, o caráter plurianual da despesa decorrente dos contratos $\mathrm{BtS}$ justifica a sua inclusão, de forma expressa no planejamento orçamentário documentado no PPA e também na LDO, permitindo incorporar os efeitos fiscais de tais contratos sobre o comportamento de médio e longo prazo das despesas públicas, contribuindo assim com maior transparência das decisões de financiamento e também com um menor risco de contingências fiscais daí decorrentes.

Ainda que se possa considerar os contratos $\mathrm{BtS}$ como operações estruturadas de financiamento, não podem tais operações serem equiparadas às operaçôes de crédito para fins legais, considerando-se a ausência de parâmetro constitucional para tanto. Conforme argumentado anteriormente, o conceito de operação de crédito albergado constitucionalmente prevê operação na qual haja a obrigação de devolução de recursos antecipados, sujeitando-se o emprestador ao risco de crédito do ente público prestamista ${ }^{708}$.

O built to suit não se confunde com o leasing, muito embora possam estar presentes ao mesmo tempo em uma mesma operação estruturada quando, ao final do prazo de locação, for resguardada opção de compra ao contratante que é beneficiário da cessão de uso do bem ${ }^{709}$. Passemos, portanto, agora a analisar essa segunda espécie contratual.

A companhia securitizadora, por sua vez, emite Certificado de Recebíveis Imobiliários nos termos do art. $6^{\circ}$ da Lei 9.514/1997, legalmente definido como um 'título de crédito nominativo, de livre negociação, lastreado em créditos imobiliários' que 'constitui promessa de pagamento em dinheiro' e providencia a averbação junto ao Oficial de Registro de Imóveis da circunscrição imobiliária competente, ou seja, no local da matrícula do imóvel objeto do contrato 'built-to-suit'."

708 Mesmo assim, do ponto de vista contábil, seria adequado o acompanhamento do saldo de parcelas a pagar do contrato em conta de controle, até o reconhecimento do passivo por regime de competência, como forma de assegurar uma completa visão da situação fiscal do ente público decorrente de tais contratos.

709 BENEMOND, Fernanda Henneberg. Op. cit., 155-6: "No que diz respeito ao leasing (ou arrendamento mercantil), entendemos que existe sim a possibilidade de o contrato built to suit ser caracterizado como tal, caso as condições estabelecidas na legislação sobre esta modalidade contratual sejam atendidas pelas partes 
O leasing, ou arrendamento mercantil, tem utilidade para as corporações na medida em que permite a utilização de bens, sobretudo bens de capital, sem que seja necessária a imobilização da totalidade dos recursos para a sua aquisição.

Embora apresente algumas semelhanças em relação ao leasing de imóvel o built to suit se distingue, entre outras características, pela contraparte não precisar ser, necessariamente, uma instituição regulada autorizada pelo Banco Central do Brasil a operar carteira de arrendamento mercantil ${ }^{710}$, podendo se dar a contratação, por exemplo, pela própria responsável pela empreitada. Além disso, é importante mencionar que, se no arrendamento mercantil, sobretudo o financeiro, existe a possibilidade de o arrendatário permanecer, ao final do prazo do contrato, com o imóvel, no caso do built to suit essa possibilidade não existe ${ }^{711}$.

Trata-se o leasing de contrato com três elementos fundamentais: (i) o aluguel do bem; (ii) a opção de compra ao final do período de aluguel; (iii) o financiamento. O leasing pode ser contratado com o próprio fornecedor do bem ou - como é o mais comum - com instituição específica que, no interesse do arrendatário, adquire o bem do fornecedor, colocando-o à disposição do interessado, na forma de aluguel por prazo determinado, com opção de compra ao final do prazo ${ }^{712}$.

Quanto à regulamentação do mercado financeiro, as operações de leasing são tratadas pela Resolução CMN n. 2.309/1996, a qual prevê a existência de duas espécies de operação: (i) o arrendamento mercantil financeiro e o (ii) arrendamento mercantil opera-

no contrato built to suit, uma das entidades autorizadas a operar no SFI, e contendo o contrato disposição concedendo à contratante a opção de, ao seu término: (i) adquirir o terreno com o empreendimento, mediante o pagamento do valor residual garantido, (ii) restituir o empreendimento ao empreendedor, ou (iii) renovar o contrato, ainda que somente no que tange ao uso e fruição do empreendimento; pode, a nosso ver, o contrato built to suit também ser caracterizado como leasing imobiliário."

710 No Brasil, as operações de arrendamento mercantil são reguladas pelo CMN e supervisionadas pelo BCB, na forma da Lei n. 6.099/1974, e da Resolução CMN n. 2.309/1996.

711 VALENÇA, Marcelo José Lomba. Op. cit:: "No Brasil o modelo de Built to suit é uma alternativa atrativa, quando comparada ao leasing imobiliário, por uma série de razões, entre as quais destacamos as seguintes:

(i) regulatória - o arrendador mercantil deve necessariamente ser uma instituição financeira autorizada a operar carteira de leasing, e, portanto, sujeito às regras aplicáveis às instituiçôes financeiras, ao passo que o Empreendedor, no modelo acima, não está sujeito a nenhuma regulamentação específica;

(ii) captação de funding - o arrendador mercantil, na qualidade de instituição financeira, está sujeito às taxas daquele mercado para captação do funding para a operação. No caso do Empreendedor, o mesmo pode utilizar recursos próprios; captar privada ou publicamente recursos de terceiros através de investimento direto ou de empréstimo, seja de partes financeiras ou não financeiras;

(iii) custo da operação - a remuneração de uma operação de leasing envolve, entre outras variantes, a possibilidade, ainda que remota, do arrendador mercantil ficar com o Imóvel e custos relacionados (custo de oportunidade de imobilização de capital, enquadramento em perfis de liquidez, manutenção e liquidação de um ativo com características específicas para o Ocupante). Em uma operação de Built to suit, é de sua essência que o Empreendedor fique com o Imóvel ao final."

712 MAXIMILIAN, Paulo. Contratos bancários, p. 180: "O leasing, assim como o contrato de desconto bancário ..., representa uma forma lícita e muito utilizada pelas empresas para fomentar e garantir melhores resultados para seus negócios, na medida em que, num primeiro momento, as mesas 'adquirem' bens sem que, para isso, tenham de mobilizar capital de forma adiantada e, num segundo, mantém seu maquinário dentro das inovações tecnológicas. (...)”. 


\section{•• Teoria jurídica do crédito público e operações estruturadas}

cional. O primeiro caso mais se aproximaria de uma operação de financiamento, considerando-se, por exemplo, que, neste caso, as despesas de assistência técnica deverão ser necessariamente de responsabilidade da arrendatária, ou que, neste caso, as contraprestaçóes deverão ser suficientes para a recuperação pela arrendadora do custo do bem e de obtenção de retorno sobre os recursos investidos. Já o segundo caso poderá não representar uma operação de financiamento a depender das suas condiçôes específicas.

A contraprestação paga pelo arrendatário incorpora normalmente diversas componentes, como o valor do bem, os custos de captação do arrendante, despesas gerais da operação, depreciação do bem, prêmio de risco e lucro do arrendante ${ }^{713}$. Para a questão que se quer discutir no presente trabalho, é essencial a ideia de valor residual e a possibilidade de acordo sobre um valor residual garantido no contrato. O valor residual (VR) nada mais é do que a diferença entre a soma das contraprestações pagas pelo arrendatário e o valor do bem acordado para a eventualidade do exercício da opção de compra. O valor residual garantido (VRG), por sua vez, corresponde ao valor mínimo que as partes concordam que o arrendante deverá fazer jus pelo contrato, ainda que o arrendatário não venha a optar pela aquisição do bem. Assim, caso a venda do bem em leilão não resulte no valor mínimo acordado, o arrendatário deverá pagar a diferença necessária, de modo a satisfazer o valor residual garantido. Não é incomum que os contratos prevejam a obrigatoriedade de antecipação dos pagamentos do VRG pelo arrendatário, sem que isso represente no momento da antecipação uma receita do arrendante ${ }^{714}$.

De nossa parte, mais uma vez, entendemos que andou mal o legislador ao mencionar no art. 29, III, da LRF as operaçóes de arrendamento mercantil como exemplos de operações de crédito, sem melhor qualificar a inclusão. Isto pois as operações de arrendamento mercantil podem ser alternativa vantajosa não apenas às operações de aquisição financiada de bens, cujo financiamento pode ser feito com o próprio vendedor do bem ou com terceiro, mas também ao aluguel de bens cuja propriedade ao final não seja necessariamente do interesse do ente público. Ademais, nas operações de arrendamento mercantil operacional, pode-se convencionar que as despesas com a assistência técnica sejam de responsabilidade do arrendante, assim como o risco de perecimento da coisa arrendada, o que terminam por afastar a operação das características fundamentais de uma operação de crédito.

Mais uma vez, portanto, entendemos que a classificação de um contrato de arrendamento mercantil com ente público como operação de crédito, para fins de aplicação das restrições constitucionais e infraconstitucionais ao endividamento do setor público de-

713 MAXIMILIAN, Paulo. Op. cit., p. 184: "Verifica-se, então, que, na composição do preço, são levados em consideração os seguintes aspectos: (a) valor de aquisição do bem; (b) custos de captação desses recursos; (c) despesas inerentes à operação; (d) depreciação do bem; (e) lucro da operação; e (f) riscos do contrato."

714 MAXIMILIAN, Paulo. Op. cit., p. 186: "O que se estabeleceu, em verdade, foi uma nova função para o valor residual (VR), que passou a ser tanto o preço contratualmente estipulado para exercício da opção de compra (VR) quanto o valor contratualmente garantido pelo arrendatário, como mínimo que será recebido pela arrendadora na venda a terceiros. Nesse caso, após a alienação (a um terceiro), o arrendatário pode ser chamado a 'completar' o valor percebido na venda, até o montante garantido (VRG).” 
Operações estruturadas: conceito, oportunidades e impactos nas finanças públicas

penderão de uma análise caso a caso, avaliando-se as características específicas da operação, com destaque para os direitos e deveres das partes.

Nada obsta que as operaçôes de crédito ocorram por meio da compra financiada de bens, o que será possível especialmente nos casos em que se recomendaria a realização de operaçãa convencional de crédito para financiamento da aquisição posterior de bens. Isso não implica dizer que todas as operações envolvendo o pagamento de prestações ao longo do tempo em troca de direitos sobre um bem se identifiquem como operação de crédito. Não haverá dúvidas, por exemplo, de que uma operação de aluguel não pode ser considerada como operação de crédito. Por outro lado, não deve haver dúvida que uma aquisição financiada de bens com garantia fiduciária é uma operação de crédito, ainda que a propriedade do bem não seja imediatamente transferida ao adquirente ${ }^{715}$.

Escrevendo ainda sob a égide da Constituição Federal de 1969, Antônio Marcello da Silva ressaltava o fato de que o leasing nem sempre apresentar natureza de operação financeira, quanto mais operação de financiamento. Entende o autor que o fato de que o leasing permite ao leasee a utilização de um determinado bem sem contar com o capital necessário para adquiri-lo não representa elemento essencial à configuração de uma operação de financiamento, posto que tal finalidade é também determinante na opção pela locação convencional em relação à compra e venda ${ }^{716}$.

715 Quanto a este último exemplo, é interessante observar a posição de Geraldo Ataliba, para quem tais modalidades de garantia não seriam possíveis no caso de compra financiada de bens pela Administração Pública em razão da afetação dos bens ao serviço público, o que se daria em razão do seu titular. ATALIBA NOGUEIRA, José Geraldo de. Empréstimos públicos e seu regime jurídico, p. 77: “Três observações esta modalidade sugere: a primeira é a insuperabilidade do procedimento de licitação para a aquisição dos bens ou serviços. A circunstância do negócio ser complexo e envolver operação de crédito não afasta a incidência da legislação específica concernente às licitações.” De nossa parte, por entendermos que a impenhorabilidade está ligada à atividade antes de à pessoa, entendemos como possível a eficácia de garantia de alienação ou cessão fiduciária de bens não afetados ao serviço público.

716 SILVA, Antônio Marcello da. Leasing, arrendamento mercantil e endividamento público: "Com muito maior razão, nem a intenção do 'lessor' de realizar um investimento financeiro, nem a função econômica do contrato, nem a motivação do 'lessee', pretensamente fixadas na liberação de capitais de giro, são idôneas para transformar o leasing em operação financeira. Isto porque os interesses financeiros que levam as partes ao leasing, cujo objetivo direto é, inegavelmente, a locação de determinado bem, esgotam-se na esfera das motivaçôes subjetivas, sem afetar a natureza do contrato, como demonstra Philomeno J. da Costa, lembrando que: 'Quando se compra a prazo um equipamento procura-se aumentar o ativo fixo com o emprego de crédito; nem por isso se configura uma operação ou um negócio em que a mercadoria seja o dinheiro’ (Philomeno J. da Costa, “Aspectos contratuais do leasing, in Simpósio Nacional do Leasing, São Paulo, 1973, p. 215 e ss.). No mesmo sentido, analisando a natureza jurídica do arrendamento mercantil, que considera sinônimo de leasing, João Henrique Renault observa que, se 'o complexo arrendamento mercantil', com suas múltiplas faces negociais, parece indicar mesmo uma intenção do locatário de não dispensar vultoso capital, de uma só vez, para aquisição dos bens de que necessita, isto é comum a toda locação: o capitalista gira com seu capital e aluga seu escritório (é locatário); os bancos não podem aplicar em imóveis, porque seus depósitos se destinam a girar; os comerciantes não compram as lojas, de ordinário, mas as locam'; e conclui: 'Na sua estrutura jurídica é que o Direito define o contrato, não exclusivamente na sua demasiado enfatizada, no caso, finalidade econômica, na que, aliás, não difere o ‘arrendamento mercantil' essencialmente do comum das locações' (João Henrique Renault, 'O arrendamento mercantil ou leasing e o município', in 'Teses do 7o Encontro Nacional de Procuradores Municipais, Fortaleza, 4 a 9.1.81', p. 51 e ss.).” 


\section{•• Teoria jurídica do crédito público e operações estruturadas}

Com base na revogada Resolução CMN n. 668/80717, o autor criticava o que entendeu ser uma usurpação da competência constitucional de fixar o conceito de operação de crédito, impondo aos entes públicos limitação em sua esfera de atuação não contida no texto constitucional. Isto se tornaria ainda mais patente diante do fato de que a referida resolução não faria qualquer distinção entre operações de arrendamento mercantil operacional e operaçôes de arrendamento mercantil financeiro ${ }^{718}$.

Finalmente, convém mencionar o chamado sale and lease back, o qual consiste na operação de venda de um bem para a arrendante pela própria arrendatária, que obtém assim os recursos decorrentes da venda sem a perda da posse do bem e suas vantagens econômicas ${ }^{719}$. Também essa operação poderá se distinguir de uma operação de crédito,

717 Resolução CMN n. 668/80, item V: "V - Estabelecer que, para os efeitos previstos nesta Resolução, bem como nas Resoluções ns. 345 e 346, ambas de 13.11.75, e 397, de 17.11.76, do Banco Central, as operaçôes de arrendamento mercantil equiparam-se às operações de crédito."

718 SILVA, Antônio Marcello da. Op. cit:: "Por isso mesmo, o endividamento público não deveria sofrer outras limitações que não as impostas pelo crédito público, isto é, pela confiança que a entidade estatal merecer de seus eventuais mutuantes. Entre nós, todavia, a Constituição da República restringe a liberdade de endividamento de Estados e Municípios através de dois dispositivos, os ns. IV e VI do seu art. 42. O primeiro, já antigo no nosso ordenamento constitucional, afeta os empréstimos externos (e, agora, quaisquer operaçóes ou convênios externos), que só podem ser validamente contratados com autorização do Senado, ouvido o Poder Executivo Federal (n. IV). O segundo, introduzido pela Carta de 1967 (art. 69, \$2 2o) e mantido pela de 1969 (art. 42, VI), diz respeito à divida consolidada e às obrigações emitidas para a sua formação, sujeitas, aquela e estas, a limitações pelo Senado Federal, por proposta do Presidente da República.

Essas restrições constitucionais ferem diretamente a autonomia das entidades estatais menores, pelo que os atos baixados para a sua efetivação só são válidos enquanto contidos nos estritos termos dos dispositivos que as estabelecem, principalmente no que concerne às limitaçōes pertinentes à dívida consolidada (de maior interesse para este estudo, pois é no art. 42, VI, da Carta Magna que, se esteiam as Res. 62/75 e 93/76 do Senado Federal e, indiretamente, a Res. CMN/BCB - 668/80). Isto porque, em face da atual conjuntura, com a inflação caminhando a passos largos, nada podendo contra ela os empíricos controles da União, que, além disso, assenhoreou-se da parte do leão da receita tributária, Estados e Municípios vêem-se constrangidos a buscar mais e mais empréstimos a longo prazo para a realização de seus objetivos institucionais.

É imprescindível, portanto, que o Senado e os órgãos que incumbiu de velar pelo fiel cumprimento de suas resoluções, o CMN e o BCB, não percam de vista o exato significado de dívida consolidada, a fim de que nem mesmo inadvertidamente venham a levar as mencionadas restrições além do permitido pela Constituição da República.

Fixemos, pois, a correta exegese do dispositivo que, excepcionando a regra constitucional da autonomia financeira das entidades estatais menores, faculta o estabelecimento de restriçōes ao seu endividamento, no que concerne à dívida consolidada e à emissão de obrigaçôes, para que possamos delimitar o campo de atuação do Senado Federal, do CMN e do BCB.”

719 MAXIMILIAN, Paulo. Op. cit., p. 183: "Existe uma característica que diferencia o lease-back das demais modalidades, que é justamente o fato de confundirem-se na mesma pessoa o arrendatário e o fornecedor do bem, funcionando como se fosse um empréstimo como dação do bem (objeto do contrato) em garantia. Todavia, não o é, pois se transfere a propriedade do bem, garantindo-se, entretanto, o direito de recomprá-lo.” Essas operações também não se confundem com o já estudado BtS, ver VALENÇA, Marcelo José Lomba. Op. cit.: "É importante destacar que operações de Built to suit não são operações de sale lease back para simples desmobilização de ativos, com aumento de liquidez e despesa operacional dedutível. O Built to suit, além de proporcionar aumento de liquidez e geração de despesa operacional dedutível, envolve necessariamente a realização de investimentos relevantes por parte do Empreendedor para atender as necessidades do ocupante tais como, mas não se limitando, à aquisição 
quando não houver nenhum compromisso de recompra por parte da arrendatária, sendo operação legítima para a melhor alocação de capital por parte do ente público.

Conclui-se, portanto, com a necessidade de atenção da doutrina jurídica para os reflexos das operações mencionadas nesse item sobre o endividamento do Estado, considerando-se as repercussōes de longo prazo desses contratos sobre a sustentabilidade fiscal. Ainda assim, não é correto do ponto de vista jurídico, afirmar que, pelo simples fato de economicamente servirem ao propósito de deslocamento de recursos ao longo do tempo, tais operações estejam sujeitas às regras da LRF aplicáveis às operações de crédito.

Assim, caso se conclua ser o caso de se reforçar a necessidade de cautela quanto à possibilidade de superexposição dos entes públicos a esse tipo de operação, comprometendo as futuras geraçôes, tal reforço deverá ocorrer pela via legislativa, contribuindo com a segurança jurídica que deve imperar no ordenamento, não devendo ser realizado por meio de interpretaçôes ampliativas que comprometam a lógica do sistema.

\subsubsection{Project finance e PPPs}

As parcerias público-privadas (PPP) são interessante mecanismo de mobilização de recursos para projetos de interesse da sociedade, em especial grandes projetos de investimentos em infraestrutura. Isto, pois a utilização de parcerias com a iniciativa privada, na forma da Lei n. 11.079/2004, tem potencial para incrementar a eficiência econômica na prestação de serviços públicos à população ou na prestação de serviços adquiridos diretamente pelo Estado.

Contudo, o caráter de longo prazo dos contratos envolve riscos à sustentabilidade fiscal dos entes públicos que devem ser adequadamente mapeados e comunicados à sociedade $^{720}$. Tais riscos estão relacionados à tendência à seleção da modalidade de contratação por PPP não por que as características econômicas ou operacionais do projeto o recomendem, mas com o objetivo de afastar os efeitos financeiros da contratação sobre o orçamento público e sobre o balanço patrimonial do governo ${ }^{721}$.

de imóveis e a construções de unidades empresariais. Desta forma, ao afirmarmos que o Built to suit é uma forma de desmobilização para o Ocupante, com o conseqüente aumento de liquidez, estamos partindo da premissa de que o mesmo alienará suas antigas e próprias unidades empresariais para alugar novas, construídas exclusivamente para atender as necessidades operacionais do ocupante."

720 OLIVEIRA, Fernão Justen. Garantias ao parceiro privado e comprometimento fiscal, p. 467: "Mais do que isso, a atenção do Parlamento voltou-se à limitação do endividamento público de longo prazo, o que já se manifestara a Lei de Responsabilidade Fiscal. A magnitude prevista para os projetos de PPP inspiram o cuidado do legislador com o comprometimento orçamentário de longo prazo, a título de contraprestação do parceiro público."

721 EUROPEAN PARLIAMENT. DIRECTORATE-GENERAL FOR EXTERNAL POLICIES. POLICY DEPARTMENT. Financing for development post-2015: improving the contribution of private finan$c e$, p. 29: "Attention needs to be paid to the costs to developing country governments of mechanisms to leverage additional private investment, particularly public - private partnerships (PPPs). As the box below shows, PPPs are by far the most expensive way to fund projects. Equally important, the cost is often non - transparent and not accountable to auditors, parliaments or civil society groups. Similarly, debt sustainability assessments do not currently take account of this cost as these are treated as off budget transactions, and PPPs have also tended to be very high risk financing." 


\section{•• Teoria jurídica do crédito público e operações estruturadas}

Para evitar essa tendência, que sacrifica o longo prazo em nome de benefícios de curto prazo, é necessária transparência nos contratos de PPP e a adoção de critérios claros e adequados de contabilização dos contratos. Nestas situações, mister ainda avaliar o impacto das referidas parcerias sobre os montantes totais de dívida do ente estatal contratante, face aos limites impostos pela legislação e à capacidade de pagamento do ente público.

A escolha por parcerias público-privadas como forma de financiamento de investimentos em infraestrutura deve ser adequadamente justificada, com base em elementos materiais e raciocínio econômico que comprove os ganhos de eficiência decorrentes da escolha da iniciativa privada como executora dos investimentos e da operação da infraestrutura após pronta. Do contrário, há sérios riscos de que a parceria se torne menos econômica do que a execução direta do objeto do contrato pelo Poder Público ${ }^{722}$.

Os investimentos em infraestrutura no Brasil correspondem a menos de $2 \%$ do $\mathrm{PIB}^{723}$. Entende-se que este número é pequeno se comparado ao número necessário ${ }^{724}$ para

722 PORTO, Telmo Giolito. Futuro sombrio para as PPPs: "Passados vários anos concluo que as PPPs unem o pior de dois mundos: o mundo dos contratos públicos e o dos contratos privados. Explico: nos contratos com o setor público, obtidos com base na Lei 8666/93, o capital é público e a legislação é pública, ou seja, aplica-se o Direito Administrativo. O empresário somente aplicará recursos em capital de giro"; ver também EUROPEAN PARLIAMENT. DIRECTORATE-GENERAL FOR EXTERNAL POLICIES. POLICY DEPARTMENT. Op. cit., pp. 29-30: "However, there is rapidly growing evidence that this has proved a very expensive method of financing, and has significantly increased the cost to the public purse. The chart below shows that PPPs are by far the most expensive way to fund projects, due to, for example, demands from equity funders and other lenders for 20-25\% annual returns on even the most bankable projects, costs of up to $10 \%$ for arranging the financing. In addition, project costs are often much higher due to limited competition or poor procurement by the private sector.

Equally important, this cost is often non - transparent and not accountable to auditors, parliaments or civil societies. Similarly, debt sustainability assessments do not currently take account of this cost as these are treated as off - budget transactions, thus perversely encouraging countries to use them in order to circumvent national or IMF agreed debt limits.

PPPs have also tended to be very high risk financing. Evidence from developed countries is that 25-35\% of such projects fail to deliver project $s$ as planned due to cost overruns, implementation delays or poor work specifications and bankruptcy or failure to repay financing. In developing countries with lower negotiation/management capacity, failure rates have been even higher. For these reasons and other concerns, LIC governments have expressed strong preferences for types of infrastructure financing other than public - private partnerships (OIF 2013)."

723 MÁXIMO Luciano. Investimento mais forte em infraestrutura deve ficar para 2019. VALOR ECONÔMICO. São Paulo: Organizações Globo, [2000?]. Diário.

${ }^{724}$ EHLERS, Torsten. BIS Working Papers n. 454: understanding the challenges for infrastructure finance, p. 2: "Infrastructure financing will need to come increasingly from the private sector. The demand for infrastructure investments is likely to grow faster than output, and therefore tax revenues. A McKinsey study estimates that the share of total infrastructure financing in GDP will need to increase from around $3.8 \%$ to $5.6 \%$ in 2020 worldwide (McKinsey Global Institute (2012)). In emerging markets, the required increase would be even more pronounced. Analysis for the G20 suggests that developing countries will need to invest an additional $\$ 1$ trillion a year up to 2020 to keep pace with the demands of urbanisation, and better global integration and connectivity (G20 (2013)). Developed countries will likely need to invest a similar amount to finance low-carbon emission energy projects through 2050; on top of necessary investments into transport and social infrastructure at potentially similar amounts." 
Operações estruturadas: conceito, oportunidades e impactos nas finanças públicas

levar o estoque de infraestrutura disponível no país a nível semelhante ao experimentado por países como a Coreia do Sul, que experimentaram crescimento econômico sustentado nas últimas décadas. Para que esse objetivo seja alcançado, estima-se ser necessário investir cerca de 5\% do PIB brasileiro, ao longo de diversas décadas ${ }^{725}$.

O investimento total da economia também vem apresentando desempenho abaixo do esperado, o que corresponde a um gargalo ao crescimento sustentado de longo prazo no país. O investimento nos últimos anos têm se aproximado de $19 \%$ do $\mathrm{PIB}^{726}$, quando seria necessário investimento de cerca de $25 \%$ do PIB para sustentar crescimento anual do produto da economia entre $5 \%$ e $6 \%{ }^{727}$.

Estudo do Banco Mundial aponta a Constituição Federal de 1988 como uma das causas do baixo desempenho dos investimentos públicos em infraestrutura no Brasil, ao lado de desempenho precário do setor privado, prejudicado por cenários regulatório e institucional desgastados. Isso ocorreria devido ao federalismo fiscal adotado na nova Constituição, que teria substituído receitas tributárias com destinação específica por outras fontes de receitas não vinculadas a investimentos em infraestrutura. Além disso, a $\mathrm{CF} / 88$ teria impulsionado o crescimento de despesas correntes, especialmente no setor de saúde e educação, que se tornaram despesas obrigatórias ${ }^{728}$.

Em um contexto de maior restrição orçamentária, com pressões decorrentes de um maior espectro de serviços públicos prestados pelo Estado de forma corrente, não é simples equacionar as receitas públicas disponíveis com a necessidade de investimentos

${ }^{725}$ OLIVEIRA, Gesner; MARCATO, Fernando S.; SCAZUFCA, Pedro. Como destravar as parcerias público-privadas, p. 16.

${ }^{726}$ Com variações para mais e para menos e com queda conjuntural mais recente, em virtude da crise política e econômica pela qual passa o país ao menos desde o segundo semestre de 2014. Conferir dados em Ipeadata, disponível em http://www.ipeadata.gov.br/ExibeSerie.aspx?serid=38432, último acesso em 29 de junho de 2017.

${ }^{727}$ Op. cit., p. 17.

728 BANCO MUNDIAL. Como revitalizar os investimentos em infraestrutura no Brasil: políticas públicas para uma melhor participação do setor privado, p. 21: "13. A Constituição de 1988 contribuiu para enfraquecer o marco institucional para infraestrutura. O financiamento do setor público - a parte central do marco institucional para o setor de infraestrutura - sofreu uma acentuada redução com a Constituição de 1988. Em primeiro lugar, a Carta Magna substituiu os impostos federais incidentes sobre alguns segmentos específicos - energia, transporte e telecomunicações - por outros não específicos no nível estadual. Por exemplo, a taxa rodoviária, que contribuiu para os investimentos nas estradas federais, foi transferida para os estados, enquanto a tarifa do setor de eletricidade foi incorporada ao ICMS dos estados. Em segundo lugar, a Constituição aumentou as transferências de verbas federais para os governos subnacionais, especialmente os municípios: a parcela municipal da receita federal e da arrecadação de impostos sobre produtos industrializados, por exemplo, cresceu de $17 \%$ para $22,5 \%$. Essa medida reduziu o montante de recursos públicos disponíveis para as despesas de capital e acarretou potenciais problemas de coordenação entre os três níveis da administração, quando há necessidade de participação dos governos subnacionais no co-financiamento de projetos de infraestrutura federais. Finalmente, a Constituição de 1988 aumentou e pré-fixou determinados gastos públicos correntes - particularmente em saúde e educação - enquanto as despesas de capital, em geral, e os investimentos em infraestrutura, em particular, foram deixados a critério dos formuladores de políticas." 


\section{•- Teoria jurídica do crédito público e operações estruturadas}

públicos $^{729}$. Além disso, é importante lembrar que, com maior rigidez orçamentária decorrente da existência de despesas de caráter obrigatório, aliada à existência de limites legais e constitucionais à elevação do endividamento, os gastos públicos em investimentos tornam-se o principal mecanismo de ajuste em casos de necessidade de obtenção de maior resultado fiscal, para a manutenção da sustentabilidade da dívida pública, ou para a condução da política macroeconômica ${ }^{730}$.

Neste contexto geral de dificuldade de impulsionar os necessários investimentos públicos em infraestrutura por razões de insuficiência orçamentária, as PPPs foram propagandeadas como sendo a solução derradeira a esse problema. Como retratadas inicialmente no Brasil pela mídia e por políticos pouco informados, as PPPs seriam capazes de atrair investidores privados para projetos públicos, resolvendo, assim, o problema da ausência de recursos públicos para investimentos ${ }^{731}$.

Parcerias público-privadas são contratos administrativos de concessão que, diferentemente dos contratos de concessão de serviços públicos regulados pela Lei n. 8.987/1995, permitem ao Poder Público ser o demandante exclusivo dos serviços (concessão administrativa) ou contribuir, no caso de serviços públicos, juntamente ao pagamento de tarifas pelos usuários dos serviços, com parte da remuneração do concessionário ${ }^{732}$.

O objetivo da previsão desta modalidade de contrato administrativo de concessão é o de tornar atrativos ao setor privado projetos de serviços e obras públicas que, de outra forma, não seriam economicamente interessantes, seja pelo risco envolvido, seja pelo elevado valor dos investimentos a serem pagos no curto prazo que vigora para as contrataçóes tradicionais de obras públicas, nos termos da Lei n. 8.666/1993.

Não é verdade, contudo, que as PPPs tenham a característica de gerar novos recursos para investimentos. As PPPs são, em essência, uma forma de financiamento de investimentos e de serviços do interesse do Estado. Não são, por conseguinte, uma forma de custeio de tais investimentos e serviços.

Isso significa dizer que ao recorrer a uma PPP, o Estado não está a produzir novas fontes de recursos para o pagamento da infraestrutura a ser instalada. Os recursos continuam tendo origem no orçamento público, com as mesmas restrições de antes sobre o

729 OLIVEIRA, Gesner; MARCATO, Fernando S.; SCAZUFCA, Pedro. Op. cit., p. 19: "Em segundo lugar, o governo conta com restrições fiscais. Não seria realista imaginar que o setor público pudesse, por si só, aumentar em três ou quatro vezes a participação de seus investimentos em infraestrutura do PIB. Um saldo de investimento público dessa magnitude seria inviável por conta da já mencionada baixa capacidade de poupança do setor público e das restrições fiscais para elevação do gasto público, sem contar a dificuldade de elaboração, gerenciamento e execução de projetos."

730 CARVALHO, André Castro. Direito da infraestrutura: perspectiva pública, p. 439: "Para se compreender o porquê da existência desses fatores, deve-se ter como premissa que as despesas com infraestrutura são, comumente, as mais atingidas em políticas de restrições orçamentárias. A despeito de elas poderem ter funções econômicas relevantes em políticas anticíclicas, é praxe no ordenamento e nas leis orçamentárias que, em períodos de austeridade financeira, sejam elas fatalmente reduzidas - ou desprogramadas. São despesas, portanto, que, em regra, não gozam de garantias financeiras."

731 MING, Celso. As PPP não decolaram. Disponível em: http://economia.estadao.com.br/blogs/celso-ming/2011/03/05/as-ppps-nao-decolaram/. Último acesso: 06 de novembro de 2014.

732 Lei n. $11.079 / 04$, art. $2^{\circ}$. 
Operações estruturadas: conceito, oportunidades e impactos nas finanças públicas

espaço fiscal existente ${ }^{733}$. Entretanto, em vez de recorrer o Estado diretamente ao financiador do projeto, o Estado o faz por meio de um parceiro privado, que passa a ser responsável pela entrega da infraestrutura e dos serviços e pelo pagamento do financiador com os recursos das contraprestações pagas pelo Estado.

Se isso é verdade, então qual o principal motivo que levaria o Estado a recorrer à contratação de um projeto por meio de PPP? A resposta a esta pergunta estaria na essência da parceria. A iniciativa privada, por suas próprias características organizacionais, estaria mais preparada para gerenciar alguns riscos de projetos de infraestrutura. Além disso, a maior agilidade administrativa de que goza a iniciativa privada, torna possível a existência de ganhos de eficiência na construção e na operação das utilidades públicas, o que se converteria num menor custo de oferta daquele bem à sociedade.

Assim, a realização de investimentos por meio de PPPs apenas se justificaria nos casos em que os ganhos de eficiência trazidos pela gestão do projeto pelo setor privado fossem superiores à economia que ocorreria ao se recorrer ao financiamento pelo próprio governo ${ }^{734}$. Isso, pois, em casos normais, o governo tem acesso a fontes de financiamento mais baratas que o parceiro privado ${ }^{735}$, o que torna a realização do investimento

733 BUDINA, Nina; BRIXI, Hana Polackova; IRWIN, Timothy. Public-private partnerships in the new the new EU member states: managing fiscal risks. World Bank: working paper n. 114., p. 2: "Creating fiscal space is critical when additional fiscal spending would likely boost medium-term growth and also pay for itself in terms of future fiscal revenue. There are different ways to create fiscal space: through revenue mobilization; optimization of the composition of budgetary expenditure (for example, by cutting low priority public expenditure); measures to limit contingent liabilities and quasi-fiscal operations of other public entities; additional borrowing or money creation; and, finally, structural reforms to promote growth."

734 Tais ganhos de eficiência podem ter origem em práticas administrativas mais modernas; em menor custo de contratação e manutenção de pessoal; em menor dificuldade na seleção de parceiros comerciais e fornecedores em geral; entre outras.

735 IMF - INTERNATIONAL MONETARY FUND. Public-private partnerships, p. 12: "This result may appear to rest somewhat uneasily with the fact that private sector borrowing generally costs more than government borrowing. However, this mainly reflects differences in default risk. The government's power to tax reduces the likelihood that it will default on its debt, and the private sector is therefore prepared to lend to the government at close to the risk-free interest rate to finance risky projects. This being the case, when PPPs result in private borrowing being substituted for government borrowing, financing costs will in most cases rise even if project risk is lower in the private sector. Then the key issue is whether PPPs result in efficiency gains that more than offset higher private sector borrowing costs." O impacto disso sobre o custo de capital e a decisão pelo financiamento público ou privado, contudo, pode ser relativizado, como se verifica em BUDINA, Nina; BRIXI, Hana Polackova; IRWIN, Timothy. Op. cit., p. 11: "PPPs are sometimes thought to have a higher cost of capital than publicly financed projects, which--with all other things being equal--would make them more expensive. The public party can usually borrow at a lower rate than the private partner, and it is sometimes thought that these extra interest payments should be weighed against any possible fiscal benefits. Borrowing costs do not give a complete picture of the cost of capital, however. The cost of capital invested in a project, whether the capital is public or private, is best thought of as its opportunity cost--the returns that could be earned by investing the capital in the best alternative project. Because projects differ in their risks, sophisticated assessments of the cost of capital adjust for differences in risk (using theories such as the capital-asset pricing model). The implicit approach taken here is to assume that the opportunity costs are the same for the public and private sectors, and that the risk-adjusted cost of capital is unaffected by the choice between a PPP and publicly financed investment (Brealey, Cooper, and Habib 1997; Klein 1997).” 


\section{•• Teoria jurídica do crédito público e operações estruturadas}

pelo parceiro privado, de início, menos econômica que a realização pelo próprio Poder Público.

Em virtude das regras aplicáveis no Brasil, a licitação para a contratação de obras e de serviços pela Administração Pública somente poderá ocorrer em caso de previsão de recursos orçamentários para o pagamento dos serviços executados dentro do exercício financeiro e de previsão do produto da obra entre as metas do Plano Plurianual ${ }^{736}$. No caso de PPPs, as exigências de previsão de recursos orçamentários e de contemplação do projeto pelo PPA estão igualmente presentes ${ }^{737}$.

Ocorre, porém, que, sendo as PPPs contratos de longo prazo $^{738}$, os desembolsos financeiros e o comprometimento orçamentário por parte do parceiro público normalmente não ocorrem no momento imediato da contratação e, em muitos casos, nem mesmo nos primeiros anos após a contratação ${ }^{739}$. Isto se deve, em parte, à proibição de que haja contraprestação da Administração Pública antes da disponibilização do serviço objeto do contrato de parceria ${ }^{740}$.

Desmistificando, o risco fiscal existente é o de que o descasamento entre a assinatura dos contratos de PPP, a realização das obras, e os respectivos pagamentos, possa provocar nos agentes públicos uma tendência à irresponsabilidade fiscal na assinatura desses contratos que, no longo prazo, poderiam ser considerados insustentáveis ${ }^{741}$. Isto pois, a depender das características específicas do contrato, a assinatura de uma PPP pode se assemelhar a um aumento no endividamento do Estado. Esse aumento não implica necessariamente dizer que a situação líquida do Estado ou da sociedade tenha piorado, visto que os benefícios sociais da infraestrutura produzida podem superar os custos envolvidos. Ainda assim, é necessário assegurar que a posição patrimonial do Estado esteja adequadamente retratada pelos relatórios fiscais, permitindo avaliar e monitorar de forma eficaz eventuais contingências passivas ${ }^{742}$.

736 Lei n. 8.666/93, art. 7o, III e IV.

737 Lei n. 11.079, art. 10, III e V.

738 No mínimo cinco e no máximo trinta e cinco anos de duração, conforme prevê o art. 5º da Lei n. $11.079 / 04$.

739 BUDINA, Nina; BRIXI, Hana Polackova; IRWIN, Timothy. Op. cit., p. 5: "A government that uses public financial resources to build infrastructure needs to make large upfront payments for construction. Unless the government increases taxes, its reported deficit and debt immediately increase. A government that uses a PPP, on the other hand, usually need not pay anything upfront. Construction bills are paid by the private partner, and the government's reported deficit and debt do not immediately increase. Therefore, PPPs can be attractive to governments under pressure to reduce their deficits and debt."

740 Lei n. 11.079/04, art. 7o. Ressalve-se, porém, a possibilidade aporte público durante a fase de investimentos (art. $\left.6^{\circ}, \$ 2^{\circ}\right)$ e a possibilidade de contrapartida de parcela fruível do serviço $\left(\operatorname{art.} 7^{\circ}, \$ 1^{\circ}\right)$.

741 BUDINA, Nina; BRIXI, Hana Polackova; IRWIN, Timothy. Op. cit., p. vii: "Governments might pay nothing now, but face the risk of paying later, perhaps when they can least afford it. The danger of PPPs is that governments' desire to avoid reporting immediate liabilities may blind them to the future fiscal costs and risks. That not only increases fiscal vulnerability, but may also lead to poorly designed projects with a higher cost than necessary or the use of PPPs when either public finance or purely private finance would be better."

742 BUDINA, Nina; BRIXI, Hana Polackova; IRWIN, Timothy. Op. cit., p. 6: "While the government's obligations to make these payments may not entail an accounting liability, they do entail an economic 
Esse ponto traz à tona a questão a respeito da adequada forma de contabilização dos contratos de PPP, de maneira a assegurar a transparência das informações patrimoniais do Estado, bem como de suas contingências. A transparência dessas informações é a única maneira de se assegurar a responsabilidade intertemporal dos agentes públicos na contratação de parcerias com a iniciativa privada na forma da Lei n. 11.079/2004, evitando situações de insolvência do Poder Público. Contudo, ainda não há suficiente clareza no Brasil, a respeito das regras aplicáveis às PPPs para fins de atendimento às restrições de endividamento contidas na Lei Complementar n. 101/2000 ${ }^{743}$.

A depender das características do contrato de PPP, a essência econômica da transação pode ser a de um endividamento de longo prazo, visando a aquisição de um ativo, ao qual a dívida se vincula. Neste caso específico, a operação se assemelharia a um arrendamento mercantil financeiro, com algumas especificidades. Em regra, é mister analisar o grau de segurança que se tem a respeito dos valores a serem despendidos a título de contraprestação por parte do Poder Público, para se concluir se se trata ou não de uma operação assemelhada a uma operação de crédito. Em caso positivo, o espírito da LRF exigiria a inclusão dessa operação nos limites de endividamento aplicáveis ao ente público ${ }^{744}$.

A experiência de Portugal com PPPs é valiosa na compreensão da importância da adequada avaliação das contingências decorrentes de PPP e de seu impacto sobre o nível de endividamento público.

A década de 1990 foi bastante produtiva para Portugal no sentido de geração de infraestrutura, por meio de parcerias com a iniciativa privada. $O$ principal motivador de tais contra-

liability. When the government is the sole purchaser of the output of the private partner, the government usually needs to commit itself to payments that equal, in present values, the cost of the investment. Subject to some qualifications set out in the next chapter, the economic liability may be the same as the debt the government would have incurred had it used public finance. Lower public debt associated with these PPPs is in large part an artifact of governments' standards for financial reporting." No mesmo sentido, IMF - INTERNATIONAL MONETARY FUND. Public-private..., pp. 4-5: After a modest start, a wave of PPPs is now beginning to sweep the world. Yet it is doing so against a background where, as in the early days of privatization, the driving force behind PPPs may be not only a quest to increase economic and social efficiency, but also the ability to bypass expenditure controls, and to move public investment off budget and debt off the government balance sheet, by exploiting loopholes in current fiscal accounting and reporting conventions."

743 OLIVEIRA, Gesner; MARCATO, Fernando S.; SCAZUFCA, Pedro. Op. cit., p. 38: "Além disso, não há clareza de como as PPPs devem ser classificadas para fins de endividamento público e aplicação da Lei de Responsabilidade Fiscal. Uma solução estrutural e definitiva permitiria que estados e municípios pudessem desenvolver seus programas de PPPs de forma sustentada e com estabilidade de regras."

744 OLIVEIRA, Gesner; MARCATO, Fernando S.; SCAZUFCA, Pedro. Op. cit., pp. 38-9: "Há entendimento divergente no sentido de afirmar que Lei de Responsabilidade Fiscal e a própria Constituição Federal não imporiam limites a contratações de PPPs. Nessa hipótese, a única limitação para a contratação de PPPs por estados e municípios seria a impossibilidade de acessar recursos federais, caso o limite de $5 \%$ da receita corrente líquida fosse ultrapassado.

Essa interpretação, porém, parece ferir o espírito da Lei de Responsabilidade Fiscal e da própria Constituição, pois permitiria a estados e municípios elevar seu endividamento com PPPs sem nenhuma limitação. Do ponto de vista econômico, por sua vez, pretende-se estimular a formação de parcerias sem, contudo, comprometer o equilíbrio das contas públicas, outro elemento fundamental para assegurar a elevação da taxa de investimento." 


\section{•• Teoria jurídica do crédito público e operações estruturadas}

tos, contudo, não foi a maior eficiência econômica que a escolha do modelo de PPPs traria ao Poder Público, mas a possibilidade de desviar das restriçóes orçamentárias impostas pelo Tratado de Maastricht (1992) ${ }^{745}$, relativas ao nível máximo de déficit e dívida por país membro.

Esse desvio na utilização das PPPs em Portugal foi um dos motivos apontados pela literatura como responsáveis pelo fracasso da estratégia de parcerias neste país e pela insustentabilidade do seu endividamento no início da década de $2010^{746}$. Segundo relatório do Banco Europeu de Investimentos, o investimento total em PPPs em Portugal ocupava nas décadas 1990-2009 o terceiro lugar em toda a Europa, atrás apenas do Reino Unido e da Espanha $^{747}$. Além disso, em relação ao PIB do país, os investimentos realizados por meio de PPPs em Portugal superaram os investimentos realizados por todos os outros países europeus pesquisados no estudo, apresentando relevantes impactos macroeconômicos ${ }^{748}$.

745 Tratado de Maastricht, Art. 104-c: "Article 104c. 1. Member States shall avoid excessive government deficits. 2. The Commission shall monitor the development of the budgetary situation and of the stock of government debt in the Member States with a view to identifying gross errors. In particular it shall examine compliance with budgetary discipline on the basis of the following two criteria: (a) whether the ratio of the planned or actual government deficit to gross domestic product exceeds a reference value, unless - either the ratio has declined substantially and continuously and reached a level that comes close to the reference value; - or, alternatively, the excess over the reference value is only exceptional and temporary and the ratio remains close to the reference value; (b) whether the ratio of government debt to gross domestic product exceeds a reference value, unless the ratio is sufficiently diminishing and approaching the reference value at a satisfactory pace. The reference values are specified in the Protocol on the excessive deficit procedure annexed to this Treaty."

746 REIS, Ricardo Ferreira; SARMENTO, Joaquim Miranda. A ascensão e queda das parcerias-público privadas em Portugal, pp. 146-7: "Em Portugal, as PPPs surgem em meados da década de 1990, apresentadas ao poder político como uma solução extremamente vantajosa, pois permitiriam a construção e a gestão de infraestruturas pelo setor privado sem qualquer impacto no déficit orçamentário. Por um lado, era a fórmula para recuperar o atraso nas infraestruturas em face dos outros países da União Europeia. Por outro, evitava os constrangimentos orçamentários decorrentes da convergência para a moeda única. Só mais tarde, durante a fase de operação, é que existiram encargos para o Estado. Sendo o modelo teórico das PPPs sustentável e considerando as experiências positivas ocorridas até então no Reino Unido, Austrália, Canadá e Nova Zelândia e o enquadramento português, quais os motivos que levam a experiência portuguesa a ser classificada como negativa hoje em dia, passados cerca de 20 anos?

O nosso estudo aponta para um conjunto de fatores que serão desenvolvidos ao longo do trabalho. Entre eles, os quatro principais consistem (1) na tentação orçamentária de realizar infraestruturas sem impacto imediato no déficit. A isto se junta (2) a falta de preparo do setor público para contratos desta complexidade e (3) o elevado número de projetos em um curto espaço de tempo. Por fim, (4) incorreta alocação do risco (sobretudo do risco de demanda, demand risk) condicionou a eficiência destes projetos."

747 KAPPELER, Andreas; NEMOZ, Mathieu. Public-private partnerships in Europe: before and during the recent financial crisis, p. 9: "The distribution in terms of project value over the past 20 years gives a similar picture. PPPs in the UK account for $53 \%$ of the total value of European PPPs (58\% in Blanc-Brude et al. (2007)). PPP market share in Spain by value is even larger than by number of projects. Portugal is the third largest PPP market by value - and has become more important in recent years. This reflects mainly the completion of some large road projects such as the Douro Litoral Toll Road or the Transmontana Highway in recent years. France, Germany and Greece together represent about $15 \%$ of the value of PPPs in Europe (11\% in Blanc-Brude et al. (2007)). The PPP market in Hungary remains the largest one among New Member States (NMS)."

748 KAPPELER, Andreas; NEMOZ, Mathieu. Op. cit., pp. 16-7: "In all countries PPP investment flows represent less than one percent of GDP. Figure 6 suggests that PPPs are of macroeconomic significance 
O resultado foi desastroso para Portugal, que diante da crise da dívida soberana que atingiu diversos países europeus, teve de reconhecer o impacto dos contratos de parceria sobre a sua situação geral de endividamento. Ao escolher a realização de investimentos por meio de PPPs como forma de ocultar o real impacto orçamentário das ações públicas, Portugal descobriu, de maneira trágica, que as parcerias não geram - como afirmado anteriormente - recursos novos, consistindo apenas em forma alternativa de financiamento de investimentos que, cedo ou tarde, serão pagos pelo Poder Público ${ }^{749}$.

A experiência de Portugal, portanto, reforça a necessidade de um monitoramento eficaz dos contratos de PPP, sob a perspectiva da sustentabilidade fiscal, não apenas do fluxo orçamentário, mas, principalmente, da sustentabilidade do endividamento público no longo prazo. Isto fica especialmente evidente se se considerar que reclassificaçõos contábeis de contratos de PPP em Portugal foram responsáveis no início desta década por um aumento de mais de 10 pp. no endividamento total reportado pelo país ${ }^{750}$.

Ademais, a experiência portuguesa ressalta a necessidade da governança dos contratos de PPPs envolverem a participação, com poder de veto, das autoridades orçamentárias e financeiras dos órgãos estatais, de forma a assegurar que as considerações fiscais sejam devidamente incorporadas ao cálculo político-administrativo da vantajosidade da contratação.

No âmbito internacional, o Fundo Monetário Internacional (FMI), entre outras atividades, elabora relatórios de cenário econômico, estatísticas fiscais e relatórios de sustentabilidade da dívida dos países-membros, ao mesmo tempo em que oferta empréstimos emergenciais em caso de desajustes na balança de pagamentos de seus membros. Para desempenhar a sua atividade de monitoramento da situação fiscal dos diversos países-membros, o FMI depende da adoção de metodologia uniforme entre os países para a elaboração de estatísticas fiscais. É com essa finalidade que o FMI mantém atualizado Manual de Estatísticas Fiscais para Governos e Guia de Estatísticas de Dívida para o Setor Público $^{751}$. Nessa ordem de consideraçōes, o FMI chama a atenção para a discussão a respeito do conceito de "governo geral" nas estatísticas fiscais.

only in Greece, Portugal, the UK and, to some extent, Spain and Ireland. Greece is in fact characterized by a small number of large PPP projects. The countries with the largest increase of PPPs relative to GDP over the past five years are Ireland, Spain, the UK and, in relative terms, France, Germany and Italy."

749 REIS, Ricardo Ferreira; SARMENTO, Joaquim Miranda. Op. cit., p. 153: "Em Portugal, usaram-se PPPs para que o investimento não fosse contabilizado no déficit. Assim, condicionou-se a decisão dos agentes públicos. Já não havia a possibilidade de escolha entre empreitada tradicional ou PPP. A obra tinha de ser realizada e em PPP por motivos orçamentários. O princípio básico em finanças de separar a decisão de investimento da decisão de financiamento (DAMODARAN, 2001) não foi aqui respeitado (SARMENTO, 2010). Adicionalmente, o Ministério das Finanças teve um controle incipiente da parte orçamentária, sobretudo nos encargos futuros, e a inexistência de uma regra fiscal impediu que se criasse um limite a esses encargos, não tendo o Tesouro a decisão final relativa aos grandes investimentos públicos."

750 IMF - INTERNATIONAL MONETARY FUND. Modernizing the Framework for Fiscal Policy and Public Debt Sustainability Analysis, p. 28: "Reclassifications of SOEs and PPPs into the general government in Europe (e.g., Greece, Hungary, and Portugal) are recent examples of how off-budget entities may end up affecting public debt. In the case of Portugal, the reclassifications increased the reported debt level by 10 percentage points of GDP in 2010."

751 Os manuais podem ser encontrados nos endereços virtuais http://www.imf.org/external/pubs/ft/gfs/ manual/ e http://www.tffs.org/PSDStoc.htm respectivamente. 


\section{•- Teoria jurídica do crédito público e operações estruturadas}

Essa discussão torna-se enormemente mais importante em países como Brasil, em que vigora grau relativamente elevado de desconcentração política e administrativa. Isto é, decisões de gasto, receitas e fontes de financiamento não estão concentradas em um único ente estatal (governo federal), mas distribuídos entre milhares de entes subnacionais (estados e municípios) e entre milhares de entidades que gozam de autonomia financeira, mas que são ligadas ao Estado, senão por uma garantia legal, por vezes, por uma garantia moral ${ }^{752}$.

Nos países em que estejam disponíveis essas informaçōes, o FMI recomenda que os dados de todos os entes subnacionais sejam consolidados para a apresentação das estatísticas do setor público consolidado. Além disso, o Fundo ressalta a importância que empresas estatais podem ter na sustentabilidade de longo prazo de um país, em função de eventuais subsídios ou garantias concedidas em favor dessas empresas pelo governo central ${ }^{753}$. $\mathrm{O}$ mesmo raciocínio se aplica a situação das garantias concedidas em projetos de PPP.

O FMI chama a atenção para a importância que uma análise cuidadosa das contingências passivas deve exercer no framework de análise da sustentabilidade do endividamento dos governos, chamando atenção especificamente para as parcerias público-privadas. No entendimento do Fundo, a história demonstra o fato de que pressóes não orçamentárias, com frequência, representam fonte importante de influência sobre a sustentabilidade da dívida no longo prazo. Neste contexto, dados insuficientes e pouca transparência nas contrataçôes e garantias por parte do Poder Público podem prejudicar a análise da real dimensão dos riscos à sustentabilidade fiscal de um governo ${ }^{754}$.

Por essa razão, o Fundo Monetário Internacional recomenda que as análises de sustentabilidade fiscal incluam análise sobre as contingências decorrentes de obrigações não decorrentes de dividas em sentido estrito, grupo no qual se incluiriam as PPPs. Esta análise poderia ser efetivada de duas formas distintas dentro dos procedimentos padronizados pelo Fundo:

752 O conceito de garantia moral, aqui, se utiliza sob a ótica de que o governo, por razôes políticas ou sociais, não tem alternativa senão garantir alguns negócios quando ocorrem situações de estresse financeiro. Um exemplo disso é o setor financeiro, no qual, por mais que haja restriçôes à garantia de solvência pelo governo, não é provável que este permita a falência de diversas instituições financeiras ao mesmo tempo, por conta dos graves efeitos econômicos e sociais daí decorrentes.

753 IMF - INTERNATIONAL MONETARY FUND. Modernizing..., p. 28: "Recent episodes of significant debt increases arising from off-budget entities or 'peripheral sectors' point to the value of widening the coverage of the fiscal accounts even beyond the general government. To the extent possible, where data are readily available, wider aggregates should be reported, in particular covering public corporations that impose large fiscal risks to the government (including those belonging to sub-national governments). A wider and enhanced view of the SOE sector and its intertwined operations with the government would help improve the risk assessment of its overall impact on debt sustainability."

754 IMF - INTERNATIONAL MONETARY FUND. Modernizing..., p. 15: "Strengthening the analysis of contingent liabilities is critical given the scope and magnitude of off-budget risk materialization. Both financial and non-financial sectors have historically benefited from government financial interventions, including financial support provided by the central bank.13 These interventions arose out of explicit and implicit guarantees to various public entities including sub-national governments and stateowned enterprises (SOEs) and banks, explicit or implicit guarantees embedded in public-private partnerships (PPPs), or support to private companies that were deemed too big to fail." 
(i) adição do valor presente de tais dívidas no estoque da dívida do governo analisado; ou, (ii) adição da estimativa de desembolsos anuais com as PPPs nas despesas projetadas, afetando o resultado primário necessário para estabilização da relação dívida/PIB ${ }^{755}$.

Essa recomendação surge em razão do próprio FMI já ter reconhecido uma tendência à utilização de PPPs como artifício para não apresentação dos efeitos dos investimentos no orçamento público e não afetação, no curto prazo, dos níveis de endividamento reportados pelos governos, conforme apresentado em trabalho publicado pelo Departamento de Assuntos Fiscais do Fundo no mesmo ano em que a Lei n. 11.079/04 foi aprovada no Brasil ${ }^{756}$.

No entendimento do FMI, duas características são centrais para diferenciar uma PPP de um contrato normal de obra ou de um contrato de prestação de serviço. A primeira refere-se ao fato de a PPP, ao lado do investimento, ressaltar a prestação de serviço pelo parceiro privado como ato contínuo à geração do ativo base. A segunda característica refere-se à transferência significativa de riscos que passarão a ser gerenciados e suportados pelo parceiro privado ${ }^{757}$. $\mathrm{Na}$ ausência dessas características, a operação perderia a sua natureza de PPP, assemelhando-se simplesmente a uma aquisição financiada de um ativo ou serviço pelo Poder Público ${ }^{758}$.

755 IMF - INTERNATIONAL MONETARY FUND. Modernizing ... Op. cit., p. 20: "Obligations arising from PPPs and SOEs can be reflected in DSA in a number of ways that depend on the extent of available information, obligations on the government to purchase services from a private operator and to honor calls on guarantees. These obligations can influence debt sustainability in much the same way as if the government had incurred debt to finance public investment and provided services itself. Country teams could present information on the present value of liabilities under PPPs or other concession arrangements. There are two ways to take non-debt obligations into account when undertaking debt sustainability analysis. First, the net present value of future payments - such as under PPP contracts - could be added to public debt. Debt sustainability would then be judged by reference to public debt plus non-debt obligations. Second, an analytically equivalent approach is to count known and potential costs of non-debt obligations as primary spending.27 More generally, the emphasis should be placed on conducting scenario analyses that correspond to alternative degrees of risk exposure to test debt projections liabilities."

756 IMF - INTERNATIONAL MONETARY FUND. Public-private ..., p. 3: “... [i] t cannot be taken for granted that PPPs are more efficient than public investment and government supply of services. One particular concern is that PPPs can be used mainly to bypass spending controls, and to move public investment off budget and debt off the government balance sheet, while the government still bears most of the risk involved and faces potentially large fiscal costs."

757 IMF - INTERNATIONAL MONETARY FUND. Public-private ... Op. cit., p. 6: "But in addition to private execution and financing of public investment, PPPs have two other important characteristics: there is an emphasis on service provision, as well as investment, by the private sector; and significant risk is transferred from the government to the private sector."

758 IMF - INTERNATIONAL MONETARY FUND. Public-private ... Op. cit., p. 19: "The private operator is typically the legal owner of a PPP asset for the period of the operating contract. However, if the government bears the risks (and derives the rewards) that are normally associated with ownership, it is in effect the economic owner of the asset. When this is the case, PPP investment is largely indistinguishable from traditional public investment, except that the payment profile for the government is different. Instead of the government making an upfront payment to cover the cost of building an asset, the private sector bears this cost and the government covers the opportunity cost of capital as part of its service payment to the private sector. This is how PPPs can be used to record initially lower government borrowing and debt than with traditional public investment." 


\section{•• Teoria jurídica do crédito público e operações estruturadas}

A transferência do risco é de vital importância para a própria economicidade da parceria público-privada, na medida em que se espera que a adoção dessa modalidade de contratação possa trazer maior eficiência para o serviço. Os riscos podem, de maneira ampla, ser categorizados em riscos de construção, riscos financeiros, risco de performance (de disponibilidade), riscos de demanda e riscos de valor residual ${ }^{759}$.

A esperada eficiência da PPP, de maneira geral, será proporcionada nos casos em que o Poder Público conheça o serviço em detalhes a ponto de ser capaz de propor e monitorar indicadores de qualidade que sejam específicos, mensuráveis, atingíveis, relevantes e temporais $^{760}$. A conexão da remuneração do parceiro privado com um conjunto de indicadores adequados é a melhor ferramenta, portanto, para garantir que os riscos alocados conforme o contrato sejam, de fato, suportados pelo agente correto, com a menor intervenção e sem necessidade de revisões e renegociações.

No já citado trabalho publicado no ano de 2004, o FMI apresenta o caso da contabilização de arrendamentos mercantis operacionais e financeiros como um paradigma importante para a forma de contabilização dos contratos de PPP. Explica o trabalho que a distinção refere-se a identificar se os riscos e benefícios decorrentes da titularidade do ativo recaem sobre o arrendador ou sobre o arrendatário. No caso de recaírem sobre o arrendador, seria o caso de um arrendamento mercantil operacional, o que garantiria apenas o registro das despesas como mera despesa de aluguel do bem. Por outro lado, no caso de os riscos e benefícios recaírem sobre o arrendatário, a essência econômica da operação seria a de um financiamento, motivo pelo qual o ativo deveria ser registrado no balanço do arrendatário, tendo como contrapartida o valor da dívida assumida na forma das contraprestaçôes a serem pagas ${ }^{761}$.

759 IMF - INTERNATIONAL MONETARY FUND. Public-private ... Op. cit., p. 11: "PPPs involve a range of different risks. These can be usefully divided into five, somewhat overlapping, categories: construction risk, which is related to design problems, building cost overruns, and project delays; financial risk, which is related to variability in interest rates, exchange rates, and other factors affecting financing costs; performance risk, which is related to the availability of an asset, and the continuity and quality of service provision; demand risk, which is related to the ongoing need for services; and residual value risk, which is related to the future market price of an asset. These risks are present in public, private, and PPP projects. PPPs seek to transfer risk from the government to the private sector. While an inflow of private capital and a change in management responsibility alone can be beneficial, significant risk transfer is necessary to derive the full benefit from such changes. The impact of risk transfer on financing costs, and the pricing of risk to ensure efficient risk transfer, then have to be addressed."

${ }^{760}$ IMF - INTERNATIONAL MONETARY FUND. Public-private ... Idem, ibidem.

761 IMF - INTERNATIONAL MONETARY FUND. Public-private ... Op. cit., p. 19: "In general, ownership of an asset and operating it entail different risks. Where the PPP contract distinguishes between the rights and obligations of the private partner in its capacity as the owner, as distinct from the operator, of an asset, risk transfer can be assessed by reference to the former. Private sector accounting standards provide guidance on how to do this for leases. A standard lease contract is between the owner of an asset (the lessor) and the user of an asset (the lessee). With an operating lease, which is similar to a rental arrangement in that a payment is made by the lessee to use an asset, the lessor bears the risks related to ownership. With a financial lease, which is a form of borrowing by the lessee to obtain the asset, the lessee bears these risks. Whether a lease is an operating or a financial lease depends on the substance of the transaction rather than the form of the contract. Factors that should influence a decision in this 
Defende o FMI que a contabilização das PPPs deveria atender aos mesmos critérios expostos acima para os casos de arrendamento mercantil, no sentido de se verificar, caso a caso, se a maior parte dos riscos e benefícios da concessão são alocados ao parceiro privado ou ao Poder Público.

Em uma PPP normal, cujos riscos tenham sido devidamente repartidos com o parceiro privado, não haverá motivos para entender que se trata de uma mera aquisição financiada de um bem, visto que os benefícios e riscos ligados ao ativo, durante toda a concessão, são suportados pelo parceiro privado. Neste caso, o ativo deverá ser contabilizado na sociedade de propósito específico (SPE) constituída para os fins da PPP, registrando o poder público as contrapartidas como despesas contratuais ordinárias.

Por outro lado, caso se verifique, pelo contrato de PPP, que o governo suporta a maior parte dos riscos e goza dos principais benefícios do ativo, então, deve-se reconhecer a natureza econômica da operação como uma operação de financiamento. Nesta hipótese, o bem deveria ser reconhecido como ativo no balanço do Poder Público, juntamente à dívida incorrida para a aquisição daquele ativo ${ }^{762}$.

Para a avaliação concreta dos riscos, o trabalho do FMI remete às regras da International Federation of Accountants (IFAC), consubstanciadas no International Public Sector Accounting Standards (IPSAS) 13 Leases, editado em dezembro de 2001. Entretanto, o próprio IFAC reconhece que, muitas vezes, a complexidade dos acordos realizados no âmbito público dificulta uma análise simplista a respeito da existência ou não de uma operação de financiamento. Neste contexto é que se destacam regras objetivas que fixam tetos de percentual de risco suportado pelo Poder Público como forma de claramente delinear os limites de uma ou outra forma de contabilização ${ }^{763}$. Essa foi a solução adotada pela União Europeia e também pelo Brasil, como será demonstrado adiante.

A conclusão é que o próprio Fundo reconhece que a análise da alocação dos riscos em contratos de PPP é uma tarefa complexa, cujos resultados podem ser afetados por diferentes detalhes do contrato ou mesmo fora dele $\mathrm{e}^{764}$.

regard are discussed in a number of private sector accounting standards for leases, such as those issued by the IASB and the Financial Accounting Standards Board (FASB) in the United States."

762 IMF - INTERNATIONAL MONETARY FUND. Idem, ibidem.

763 IMF - INTERNATIONAL MONETARY FUND. Public-private... Op. cit., p. 21: "However, IFAC acknowledges that the public sector may enter into a variety of arrangements for the provision of goods and services involving the use of dedicated assets where it is unclear whether a financial lease is involved. Some national standards include quantitative criteria to establish the existence of a financial lease. For instance, the state of Victoria in Australia focuses on three criteria to determine whether a Partnerships Victoria PPP contract should be classified as a financial lease: does the government finance 90 percent or more of asset costs; does the service contract cover 75 percent or more of the useful life of the asset; and does the contract include a 'bargain basement provision' whereby the government can purchase the asset at the end of the contract for substantially less than its residual value?"

764 IMF - INTERNATIONAL MONETARY FUND. Public-private... Op. cit., p. 22: “Assessing risk transfer is likely to remain a difficult exercise. Certainly, full disclosure of the terms of original and renegotiated PPP contracts, along with some simplification and standardization, is essential. However, the legal complexity of PPP contracts means that they will always be hard to interpret, and this will complicate assessments of risk transfer even when the focus is on a few key risks. Moreover, the PPP 


\section{•• Teoria jurídica do crédito público e operações estruturadas}

A dificuldade na avaliação dos riscos gera ainda outra dificuldade prática. Ainda que se conclua que o ativo deve ser reconhecido como ativo público, assim como as contraprestações deverão ser apresentadas como dívida, resta a incerteza a respeito de qual o valor que será pago a título de contraprestação, visto que, mesmo que o governo absorva a maior parte do risco, o parceiro privado ainda assim pode se sujeitar a uma parcela de incerteza que fará variar a sua remuneração ao final do contrato. Neste caso, a provisão do valor das contraprestações - que seria recomendável para fins de análise de sustentabilidade fiscal - torna-se sujeita a um grau de incerteza muito elevado, obrigando o Poder Público a manter controle estatístico dos diferentes eventos, com suas respectivas probabilidades de ocorrência, de maneira a registrar na contabilidade o valor mais próximo da realidade ${ }^{765}$.

Além disso, deve-se reconhecer que, sob o princípio da competência, que rege o framework do FMI vigente para as estatísticas fiscais, não há fundamento para registro como obrigação no balanço patrimonial do valor presente dos futuros pagamentos do contrato, uma vez que, sob esse princípio, a obrigação apenas surge após a prestação do serviço. Assim, apenas após a entrega do serviço pelo parceiro privado o Poder Público poderia reconhecer a obrigação referente àquele contrato ${ }^{766}$.

A solução nestes casos será aquela que a prudência costuma recomendar: máxima transparência. Os governos devem, ainda que não o façam com a inclusão dos ativos no balanço patrimonial em conjunto com as dívidas, realizar full disclosure das operaçóes de PPP realizadas, permitindo ao público interessado a leitura da íntegra dos contratos, o acesso aos valores pagos correntemente, das garantias concedidas, e de outras informaçóes que possam ser de relevância para a análise da sustentabilidade fiscal das obrigações assumidas na forma de contratos de PPP.

Com relação à contabilização das PPP em que a maior parte do risco recaia sobre o Poder Público, o FMI admite três formas distintas de retratar a operação: (i) contabiliza-

contract may not tell the whole story, since it is only relevant to ex ante risk transfer. Political pressure for the government to bail out large projects (that are too big to fail), and providers of essential services, may mean that the government in fact bears more risk than the contract suggests."

765 IMF - INTERNATIONAL MONETARY FUND. Public-private ... Op. cit., p. 27: "However, there is an issue as to what her future contract payments should also be capitalized and counted as a liability. The argument for not doing so is that these payments are contingent on the satisfactory delivery of a service, and can anyway be changed over the life of an operating contract as service need s and demands, supply technology, etc., change. The counterargument is that taking on a contractual obligation does more than limit fiscal policy flexibility in the future. In particular, assessments of debt sustainability are affected in the same way as if the government had incurred debt to finance public investment and provide the service itself, in that larger primary surpluses or smaller primary deficits (exclusive of the PPP payments) have to be generated to ensure a desired debt path. This being the case, the net present value of future contract payments under PPPs less any contractual receipts from the private sector (e.g., concession fees), both discounted using a risk-free interest rate, should be added to government debt when assessing debt sustainability.”

766 IMF - INTERNATIONAL MONETARY FUND. Public-private ... Op. cit., p. 27, n. 42: "It should be noted that there is no basis to record the present value of future contract payments as a liability under GFSM 2001 given that a commitment to pay for a service cannot be accrued until the service is delivered. Rather, an ad hoc adjustment has to be made to the nominal debt measure reported as a memorandum item to the balance sheet." 
ção semelhante a um leasing financeiro; (ii) contabilização de uma operação de lease and lease-back, envolvendo um leasing financeiro e um leasing operacional; (iii) contabilização de baixa do investimento e da dívida.

Para que a compreensão das três metodologias seja possível, é necessário conhecimento das regras de elaboração de estatísticas do setor público editadas pelo FMI, ou seja, é necessário conhecimento do GFSM, sobre o qual não nos aprofundaremos por não ser o objetivo do presente trabalho. É necessário também ter em mente que a metodologia do FMI tem por objetivo permitir avaliar o impacto que as ações do governo têm sobre a demanda agregada, em termos macroeconômicos.

Sob o primeiro método admitido (leasing financeiro), o governo deveria reconhecer o ativo de infraestrutura no seu ativo ao mesmo tempo em que reconheceria uma dívida de igual valor no seu passivo. Ao longo dos exercícios, os pagamentos dessa dívida financeira ocorreriam por meio de registros de despesas de juros e despesas de amortização. Ao mesmo tempo, deveria ser reconhecida a depreciação do ativo no balanço. Neste método, apenas haveria registros no Demonstrativo de Operaçōes do Governo (Statement of Government Operations) e no Balanço Patrimonial (Government Balance Sheet).

Esta alternativa, contudo, não é totalmente adequada, pois não explica a utilização do ativo pelo parceiro privado ao longo da vigência do contrato de PPP. Deve-se ainda lembrar que, ainda que o ativo permaneça registrado no balanço patrimonial do parceiro privado, para fins de consolidação das contas nacionais, será necessário excluir esse ativo do balanço consolidado do setor privado, sob pena de dupla contagem do estoque de investimentos da economia ${ }^{767}$.

A alternativa seguinte consiste em considerar existente uma operação de leasing financeiro do parceiro privado para o ente público, o que explicaria a contabilização do ativo no balanço do governo, seguido de uma operaçáo de leasing operacional do governo para o parceiro privado. Nessa hipótese, os pagamentos do governo como contraprestação do ativo seriam considerados despesas de juros e de amortização, mas o pagamento seria realizado contra a obtenção de uma receita pública patrimonial de arrendamento mercantil operacional. Assim, a redução nas disponibilidades financeiras do ente estatal apenas serviriam ao pagamento da parte de serviços da PPP, visto que a dívida referente ao arrendamento mercantil financeiro seria paga contabilmente com receitas auferidas no arrendamento mercantil operacional.

Finalmente, a abordagem de contabilização de baixa do investimento e da dívida consiste na simples baixa contábil da depreciação do ativo e da dívida, no seu valor total, lançando-se eventual diferença no Demonstrativo de Outros Fluxos Econômicos (Statement of Other Economic Flows), que, por sua vez, registra alteraçôes no resultado líquido do patrimônio do governo causadas por variaçōes em preços e volumes não captadas no

${ }^{767}$ IMF - INTERNATIONAL MONETARY FUND. Public-private ... Op. cit., p. 41, n. 68: "A further problem is that, from the standpoint of the national accounts, the transfer of the asset to the government balance sheet has to be matched by its removal from the private sector balance (even though it remains on the private operator's own balance sheet), otherwise it would lead to double counting of PPP investment in the national accounts." 
Demonstrativo de Operações do Governo. Essa é a alternativa mais simples, no sentido de que apresenta o menor número de lançamentos contábeis.

No âmbito da União Europeia, por outro lado, todos os países-membros devem preparar as suas estatísticas nacionais em conformidade com uma série de regras padronizadas desenvolvidas pelo órgão central de estatísticas da Comissão Europeia (Eurostat). Esse conjunto de regras é chamado de European System of Integrated Economic Accounts (ESA) e atualmente está em vigência o ESA $2010^{768}$.

O ESA anteriormente em vigor era o ESA 95 e, no princípio, não trazia nenhuma regra específica para a contabilização de PPP. No mesmo ano em que entrou em vigor a Lei das PPP no Brasil (Lei n. 11.079/04), a Comissão Europeia, por meio do seu órgão central de estatísticas Eurostat, editou regramento para a contabilização de PPP, considerando os riscos suportados pelo parceiro público como elementos centrais na determinação da natureza de dívida ou não de tais contratos ${ }^{769}$. Tais regras estão incorporadas na edição vigente do Manual de Déficit e Dívida (MGDD - 2016), que implementa o ESA 2010, assim como a versão anterior do MGDD de 2014.

A questão principal envolvida diz respeito a se os ativos gerados pela ação do parceiro privado na PPP devem ser considerados como ativos pertencentes ao patrimônio público ou se devem ser contabilizados como pertencentes à sociedade privada contratada para execução da PPP. Essa questão tem reflexos imediatos sobre a posição de endividamento do governo, na medida em que a contrapartida da formação desse ativo no patrimônio público consiste na geração de um passivo a favor do parceiro privado.

Para essa classificação, o elemento essencial é o risco. Conforme o MGDD, as PPPs devem ser mantidas fora do balanço patrimonial do governo se a maior parte dos riscos de construção, de disponibilidade e de demanda são suportados pelo parceiro privado. Tais riscos referem-se fundamentalmente aos riscos ligados aos custos da construção e eventuais atrasos na entrega da obra; aos riscos ligados à oferta dos serviços em conformidade com critérios de qualidade e quantidade definidos em contrato; e aos riscos de a demanda pelo serviço ofertado não atender às estimativas inicialmente apresentadas ${ }^{770}$.

768 Em vigor desde $1^{\circ}$ de setembro de 2014

769 Decison n. 18/2004. Ver também EPEC. Risk distribution and balance sheet treatment: practical guide, p. 6. "ESA95 is a system for producing economic statistics and does not contain explicit rules for PPPs. ESA95 seeks to record the economic reality of transactions rather than their legal form. This can involve looking through complex financial operations to understand who bears the financial risks and who benefits from the rewards, irrespective of how the contracts have been legally constructed.

In practice, it has been necessary for Eurostat to supplement the general rules of ESA95 with additional guidance relating for PPPs. A New decision of Eurostat on deficit and debt - Treatment of public-private partnerships 10 was published on 11 February 2004 and concerns the statistical treatment of long-term partnership contracts between government and non-government units. It specifies the treatment of PPPs and its recording in government deficits and debt.

This decision led to more descriptive guidance, also issued by Eurostat in 2004 - Long term contracts between government units and non-government partners (Public-private partnerships) (the "old manual" 11) - and expanded in 2010 by the revised Manual on Government Deficit and Debt - Implementation of ESA95 (referred to below as "MGDD” 12)."

770 EUROSTAT. Manual on government deficit and debt, p. 308: "As a result of the methodological approach followed, in national accounts the assets involved in a PPP can be considered non-government assets 
Em termos práticos, o Manual define que os ativos deverão ser contabilizados pelo parceiro privado caso este suporte o risco de construção e, pelo menos, um dentre os riscos de disponibilidade e de demanda. Para verificação da alocação de tais riscos, porém, não é suficiente analisar a matriz de risco, sendo necessário igualmente atentar para a existência ou não de cláusulas de garantia que possam acabar por alterar o custo financeiro da realização de um eventual risco, alocando-o, na prática, ao governo ${ }^{771}$. Além disso, a propriedade do bem ao final da concessão é considerada como um critério adicional, nos casos em que o critério de alocação do risco seja inconclusivo.

Ainda que representem um avanço em termos de classificação objetiva da forma de contabilização das PPPs, a proposta adotada pela Eurostat apresenta dois problemas essenciais. Em primeiro lugar, os limites objetivos da transferência de risco não são definidos. Por exemplo, se a remuneração do parceiro privado variar de modo a receber a recomposição de $30 \%$ da majoração dos custos de construção, isto significará que o risco de construção está alocado com o parceiro privado ou público? Em segundo lugar, pela proposta adotada, uma PPP não será contabilizada no balanço patrimonial do ente público se os riscos de construção e disponibilidade pertencerem ao parceiro privado, ainda que os serviços se dirijam unicamente ao Poder Público ${ }^{772}$.

Apesar dos problemas apresentados, a proposta busca privilegiar a essência econômica da operação sobre a forma legal do contrato e dos títulos de propriedade, o que é um princípio fundamental da contabilidade aplicável tanto ao setor privado quanto ao setor público. Por esta razão, o critério da alocação dos riscos é também utilizado no Brasil, como será apresentado adiante.

No caso brasileiro, ao lado dos limites de endividamento já tratados em tópico anterior, há limite específico para o caso de PPPs, no artigo 28 da Lei n. 11.079/2004. Muito

only if there is strong evidence that the partner is bearing most of the risks attached to the asset (directly and linked to its use) of the specific partnership. Therefore the analysis of the allocation of risk between government and the private partner is the core issue. Here, the notion of risk refers to the impact (on revenue or profit) of evident actions by one party (related to construction, maintenance operations, provision of service for which it has been given clear responsibility) and/or the result of the behavior of other economic agents for which the activity is carried out (such as a shift in the demand for the service, by a government unit or by end-user). Bearing the risk implies to be entitled to take actions in order to prevent them or mitigate their impact."

771 EUROSTAT, Op. cit., p. 309: "If these conditions are met, it is also important to consider other mechanisms in place (such as a guarantee or grantor financing) in order to check whether there could be an allocation of these risks to government, in which case the treatment of the contract is similar to the treatment of an operating lease in national accounts; it would be classified as the purchase of services by government."

772 BUDINA, Nina; BRIXI, Hana Polackova; IRWIN, Timothy. Op. cit., p. 15: "According to a 2004 ruling by Eurostat, for example, a PPP remains off a government's balance sheet if the private partner bears construction and availability risks (that is, risks related to construction costs and delays and whether the private partner has constructed, operated, and maintained the asset to ensure that it can provide the required service) (Eurostat 2004). However, in a PPP that meets the two criteria from the above referenced Eurostat ruling, but where the government is the sole purchaser of the output, the governments would accumulate debt-like liabilities without affecting its fiscal deficit and debt figures (at best, mentioning the liabilities only in a note to financial statements)." 


\section{•• Teoria jurídica do crédito público e operações estruturadas}

se critica na doutrina a respeito da imposição de tais limites, por meio de lei ordinária, quando a matéria (finanças públicas no âmbito da federação) deveria ser tratada em lei complementar ${ }^{773}$. Além disso, questiona-se a respeito de se tal limite, por ser específico, suplementaria o limite geral para operaçôes de crédito, ou se se aplicaria em conjunto com os limites das Resoluçôes SF n. 40/01 e n. 43/01774. A resposta a essa pergunta passa pelo reconhecimento da natureza do contrato de PPP, ora como dívida, ora como mera contraprestação por serviço, a depender de características específicas do contrato, que serão abordadas em detalhes à frente $\mathrm{e}^{775}$.

Segundo a Lei n. 8.666/93, o prazo de duração de contratos administrativos é, em regra, equivalente ao prazo de vigência do crédito orçamentário que dá base à contratação, ou seja, no máximo um ano. Uma das exceçōes a essa regra consiste na contratação de projetos cujos produtos estejam contemplados nas metas estabelecidas no Plano Plurianual, os quais poderão ser prorrogados se houver interesse da Administração e desde que isso tenha sido previsto no ato convocatório. Também a Lei n. 8.987/95 (Lei de Concessões e Permissóes de Serviços Públicos) prevê a existência de contratos por prazos mais longos, de maneira a conferir estabilidade à relação jurídica, permitindo a amortização de investimentos em maior tempo.

De maneira geral, tais contratos não são considerados como dívida, embora imponham uma obrigação financeira de pagamento à Administração Pública, por prazos, por vezes, superiores a doze meses. Isso ocorre, pois, nestes contratos, a obrigação financeira do Poder Público, quando há ${ }^{776}$, surge apenas em decorrência da prestação de um serviço

773 Ver, por exemplo, CARVALHO. André Castro. Op. cit., p. 458: "É interessante salientar que o artigo 28 da Lei de PPPs não possui aceitação pacífica na doutrina brasileira. Entende-se que houve um desvio de finalidade na edição do dispositivo, tendo em consideração que somente em leis complementares federais é que poderia haver disciplina a respeito de finanças públicas. A Lei das PPPs, por sua vez, é lei ordinária federal e não lhe caberia fixar limites de despesas para os demais entes da federação. Essa é a advertência, por exemplo, de Fernando Dias Menezes de Almeida e Maria Sylvia Zanella Di Pietro."

774 OLIVEIRA, Gesner; MARCATO, Fernando S.; SCAZUFCA, Pedro. Op. cit., pp. 38-9: "Há entendimento divergente no sentido de afirmar que Lei de Responsabilidade Fiscal e a própria Constituição Federal não imporiam limites a contratações de PPPs. Nessa hipótese, a única limitação para a contratação de PPPs por estados e municípios seria a impossibilidade de acessar recursos federais, caso o limite de $5 \%$ da receita corrente líquida fosse ultrapassado.

Essa interpretação, porém, parece ferir o espírito da Lei de Responsabilidade Fiscal e da própria Constituição, pois permitiria a estados e municípios elevar seu endividamento com PPPs sem nenhuma limitação. Do ponto de vista econômico, por sua vez, pretende-se estimular a formação de parcerias sem, contudo, comprometer o equilíbrio das contas públicas, outro elemento fundamental para assegurar a elevação da taxa de investimento."

775 CARVALHO. André Castro. Op. cit., p. 460: “[A] STN, por meio da Portaria n. 437/2012, estabeleceu que a despesa nas concessões patrocinadas deve ser considerada como despesa corrente de subvenção econômica, enquanto que, nas concessões administrativas, despesa corrente de prestação de serviços. No entanto, no caso de assunção de risco relevante, nos termos já destacados algures, é considerada como assunção de dívida proporcional aos riscos assumidos.

776 Lembrando que em contratos de concessão puros, não há contraprestação por parte do Poder Público, auferindo o concessionário a sua remuneração apenas por meio da cobrança de tarifas, junto aos usuários do serviço. 
e no momento em que este é prestado. Em outras palavras, se o serviço não for prestado, não há obrigação financeira. Não há assunção de risco pelo ente público contratante. Essa condicionalidade é essencial para explicar a diferença com relação a contratos de venda a prazo ou contratos de arrendamento mercantil financeiro, por exemplo, os quais podem ser considerados como formas de operação de crédito.

Os contratos de PPP, como adiantado, podem, por suas características particulares, alocar maior ou menor risco no parceiro privado ou no parceiro público. Quando a maior parte do risco está alocada no parceiro privado, a situação se aproxima de um contrato comum, no qual o pagamento se dá como contraprestação de um serviço prestado, sendo a entrega desse serviço uma condição para a existência da obrigação jurídica de pagamento.

Entretanto, quando a maior parte do risco é alocada ao parceiro público, isto implica dizer que a remuneração do parceiro privado (ou reflexamente a obrigação financeira do parceiro público) é relativamente fixa e independente da entrega do serviço. Nestes casos, a PPP, em sua natureza econômica, apresenta-se como uma operação de crédito, por meio da qual o que se almeja verdadeiramente é a constituição e obtenção da propriedade de um ativo de infraestrutura ${ }^{777}$.

Os critérios pelos quais objetivamente, no Brasil, deve-se reconhecer um caso ou outro, isto é, deve-se reconhecer o contrato de PPP, como uma operação de crédito da qual se origina uma dívida ou uma operação normal de aquisição de um serviço, serão apresentados a seguir. Entretanto, sabendo que haverá casos em que as PPPs são veículo de endividamento, mister concluir que, nestes casos, deverá haver o respeito não apenas ao limite imposto no artigo 28 da Lei n. 11.079/2004, mas igualmente aos limites de endividamento relacionados nas Resoluções n. 40 e 43, de 2001, do Senado Federal.

Com relação aos aspectos contábeis, o artigo 67 da LRF prevê a criação de Conselho de Gestão Fiscal (CGF), constituído por representantes de todos os Poderes e esferas de Governo, do Ministério Público e de entidades técnicas representativas da sociedade, com atribuições de: (i) harmonização e coordenação entre os entes da Federação; (ii) disseminação de práticas que resultem em maior eficiência na alocação e execução do gasto público, na arrecadação de receitas, no controle do endividamento e na transparência da gestão fiscal; (iii) adoção de normas de consolidação das contas públicas, padronização das prestações de contas e dos relatórios e demonstrativos de gestão fiscal de que trata esta Lei Complementar, normas e padrôes mais simples para os pequenos Municípios, bem como outros, necessários ao controle social; (iv) divulgação de análises, estudos e diagnósticos.

Passadas quase décadas da entrada em vigor da referida lei, o CGF ainda não foi regulamentado e instituído. Por esta razão, aplica-se a regra transitória do artigo $50, \$ 2^{\circ}$, que prevê que a edição de normas gerais para a consolidação das contas públicas caberá ao órgão central de contabilidade da União, enquanto não implantado o Conselho.

777 CARVAlHO, André Castro. Idem, ibidem: "Pelo teor do artigo 3º $\$ 11^{\circ}$, II, da Resolução n. 43/2001, é equiparada às operações de crédito a assunção de obrigação, sem autorização orçamentária, com fornecedores para pagamento a posteriori de bens e serviços. Como as PPPs envolvem a assunção de obrigações pelo Estado com particulares por períodos superiores a um exercício financeiro - e, inclusive, superior ao prazo quadrienal do PPA -, elas se enquadram como operações de crédito por equiparação quando houver assunção de risco relevante e que impactos na sua situação fiscal. 
A Lei n. 10.180/01, que organiza e disciplina os sistemas de planejamento e de orçamento federal, de administração financeira federal, de contabilidade federal e de controle interno do Poder Executivo federal, estabelece em seu artigo 17 que integra o Sistema de Contabilidade Federal a Secretaria do Tesouro Nacional, como seu órgão central. Isso implica dizer que, até a criação do Conselho de Gestão Fiscal previsto no artigo 67 da LRF, caberá à Secretaria do Tesouro Nacional (STN) a edição de normas gerais para a consolidação das contas públicas.

A primeira questão que surge neste ponto consiste em estabelecer o tamanho das atribuições delegadas à STN pela LRF até a criação do CGF. Na literalidade do artigo 50, $\$ 2^{\circ}$, o que se verifica é uma delegação para a edição apenas de normas gerais para a consolidação das contas públicas. Ou seja, nem todas as competências do Conselho em matéria contábil podem ser exercidas pela STN, visto que além da consolidação das contas públicas é também competência do Conselho de Gestão Fiscal em matéria contábil a padronização das prestações de contas e dos relatórios e demonstrativos de gestão fiscal de que trata a LRF, estabelecendo normas e padrões mais simples para os pequenos municípios, bem como outros, necessários ao controle social.

Na prática, porém, não é isso que se tem observado no exercício da competência delegada à STN. Em verdade, o que se verifica é que a Secretaria do Tesouro Nacional vem extrapolando a sua competência delegada pela LRF, exercendo plenamente as competências que seriam do Conselho de Gestão Fiscal, em especial as competências de padronização das prestações de contas e das regras de contabilidade aplicáveis a todo o setor público no Brasil.

Em que pesem tais considerações introdutórias a respeito da competência para o estabelecimento de regras cogentes aplicáveis a todos os entes federados, as regras editadas pela STN servem de importante referência para a contabilidade pública em estados e municípios, que, em geral, esforçam-se por atender às determinações do órgão central de contabilidade da União.

Neste contexto, torna-se de grande importância conhecer as regras fixadas pela STN para registro de contratos de parceria público-privada na contabilidade pública. Tais regras foram apresentadas na Portaria STN n. 614, de 21 de agosto de 2006, e levam em consideração opções e recomendações apresentadas no âmbito internacional, conforme detalhadas no início do presente item.

É importante inicialmente notar que o parágrafo único do artigo $1^{\circ}$ da referida Portaria estabelece o âmbito de aplicação das suas regras, deixando claro que são aplicáveis aos órgãos da Administração Pública direta, aos fundos especiais, às autarquias, às fundações públicas, às empresas públicas, às sociedades de economia mista e às demais entidades controladas direta ou indiretamente pela União, estados, distrito federal e municípios, com vistas a assegurar a homogeneidade de tratamento contábil necessária à consolidação das contas do setor público.

No artigo 3o a Portaria n. 614 fixa a determinação de que "os direitos futuros reconhecidos pelo ente público, decorrentes de pagamentos preestabelecidos em contrato, e não relacionados à efetiva prestação do serviço, deverão ser registrados como ativo patri- 
monial a partir da sua efetiva constituição ou ampliação, no caso de cessão de uso pelo parceiro público.”

O primeiro ponto a se atentar refere-se ao fato de que se trata de reconhecer direitos futuros sobre um ativo, ou seja, a presente regra apenas se aplica aos ativos reversíveis ao final da concessão. Em seguida, verifica-se que o artigo menciona direitos decorrentes de pagamentos "não relacionados à efetiva prestação do serviço". Em outras palavras, o artigo refere-se à parcela da contraprestação do parceiro privado que visa a remunerar a construção e a manutenção do ativo de infraestrutura e não a prestação do serviço, que não deve constituir ativo patrimonial. Finalmente, o artigo $3^{\circ}$ limita a sua aplicação aos casos em que haja cessão de uso do bem pelo parceiro público, lembrando que o foco da análise deve ser sobre a essência econômica da operação e não sobre a formalidade jurídica da operação, em atendimento ao princípio da essência sobre a forma, insculpido no artigo $2^{\circ}$ da Portaria.

A exemplo da regra fixada pelo Eurostat apresentada anteriormente, a STN fixou critério baseado no risco suportado pelo Poder Público como forma de determinar o registro do ativo no patrimônio do ente público. Assim é que o artigo $4^{\circ}$ da Portaria n. 614/06 estabelece que a assunção pelo parceiro público "de parte relevante de, pelo menos, um entre os riscos de demanda, disponibilidade ou construção será considerada condição suficiente para caracterizar que a essência de sua relação econômica implica registro dos ativos contabilizados na SPE no balanço do ente público em contrapartida à assunção de dívida de igual valor decorrente dos riscos assumidos."

Nos incisos do $\$ 1^{\circ}$ do artigo $4^{\circ}$ são definidos os critérios para se poder considerar a assunção do risco como sendo de "parte relevante". Em resumo, o critério adotado consiste na possibilidade de o Poder Público garantir mais de $40 \%$ da remuneração original do parceiro privado, independentemente da demanda, disponibilidade ou custo de construção. Pelo contrário, quando não há garantia de remuneração pelo Poder Público de pelo menos $40 \%$ da contraprestação, em face de riscos de demanda, disponibilidade ou construção, não deverá haver registro do ativo como bem público, com o registro da contrapartida em dívida.

Como se verifica, a abordagem adotada pela STN assemelha-se à abordagem aplicável às operações de arrendamento mercantil financeiro, nas quais se registra o passivo financeiro ao mesmo tempo em que faz o reconhecimento do ativo adquirido. A inspiração nas regras relativas ao arrendamento mercantil é expressamente reconhecida pela STN no item 1.i) da Nota Explicativa anexa à Portaria n. 614/06778.

778 Arrendamento mercantil - o aparecimento desta modalidade requereu introdução de normativos específicos apoiados na essência econômica desta transação, que buscaram na caracterização do benefício econômico decorrente da utilização do bem objeto do arrendamento o elemento capaz de definir seu registro contábil: "A classificação do arrendamento mercantil adotado nesta norma é baseada na extensão pela qual os riscos e recompensas incidentes sobre a propriedade do ativo arrendado recaem com o arrendador ou com o arrendatário" (IPSAS, 2001, p.293). O arrendamento configura contrato pela qual uma das partes - denominada arrendador - retém a titularidade de determinado bem que é colocado à disposição da outra parte - denominada arrendatária - para atuar em processos econômicos. Mesmo reconhecendo-se a complexidade do s contratos de arrendamento mercantil, optou-se por classificá-los para fins contábeis em duas categorias: financeiro e operacional: "Um arrendamento mercantil é classi- 
Além do registro do ativo e da dívida respectiva, a Portaria n. 614/06 determina em seus artigos $6^{\circ}$ e $7^{\circ} \mathrm{o}$ registro como passivo de outras obrigaçôes não relacionadas à prestação efetiva de serviços, decorrentes de garantias concedidas ao parceiro privado ou em seu benefício como cobertura de riscos.

O registro de tal passivo deverá refletir o valor presente das obrigaçôes estimadas por meio de metodologia estatística que permita identificar com grau de confiança de pelo menos $85 \%$ a probabilidade de ocorrência de cada evento. No caso de a estimativa não atingir o nível de $85 \%$ de confiança, o valor da perda registrada deverá ser provisionado com probabilidade acumulada de ocorrência de $95 \%$, isto é, deverá ser adotado o valor da provisão que corresponda a $95 \%$ dos valores testados. Por fim, caso não sejam realizados estudos estatísticos que permitam analisar o valor em risco, deve-se adotar o valor da maior perda possível ou o valor presente do contrato de PPP 779 .

Com relação às contingências passivas decorrentes da contraprestação pela prestação dos serviços objeto da PPP pelo parceiro privado, a Portaria STN n. 614/06 determina, em seu artigo 10, que devam ser registrados contabilmente em contas contábeis típicas de "compensado" até que sejam reconhecidos como passivos ou ativos patrimoniais. Isto é, tais valores, que deverão ser reconhecidos por seu valor presente, não devem integrar de imediato o passivo patrimonial. Essa regra é importante como garantia de respeito ao princípio da competência, visto que não se pode reconhecer uma obrigação decorrente de um serviço prestado antes que este seja efetivamente entregue.

As regras apresentadas deixam clara a ideia de que a STN considera, em casos em que a maior parte do risco da PPP seja suportada pelo Poder Público, que a PPP deva ser caracterizada como uma dívida, pelo menos até o montante do ativo que passa a ser incorporado ao patrimônio público.

Sendo uma dívida na sua essência econômica, cabe questionar se a STN consideraria dívida desta natureza como inserida no conceito de operação de crédito a que remete a LRF, com repercussões sobre a aplicação dos limites de endividamento previstos nas resoluções do Senado Federal.

Analisando as diversas edições do Manual de Demonstrativos Fiscais publicado pela Secretaria do Tesouro Nacional, verifica-se que, no entendimento da STN, até a 7a edição ${ }^{780}$, as dívidas decorrentes de PPP, na forma da Portaria n. 614/06 integravam a dívida

ficado como financeiro se forem transferidos substancialmente os riscos e recompensas incidentes sobre a propriedade" (IPSAS, 2001, p. 293). As normas indicam ainda as características do contrato de arrendamento mercantil que permitiriam caracterizar a operação como financeira. Configurado que se trata de arrendamento financeiro, determina-se que o valor do bem arrendado deva integrar o imobilizado no ativo permanente da entidade arrendatária, em contrapartida ao valor total das contraprestaçóes e do valor residual que deverá ser registrado no passivo circulante ou no exigível a longo prazo. O bem objeto do arrendamento deve ser depreciado de forma consistente com a metodologia aplicável a outros bens de natureza semelhante, enquanto a diferença entre o valor do bem arrendado, adicionada do eventual valor residual, deve ser registrada como encargo financeiro (CFC, 2001, p. 4).

779 A Nota Explicativa anexa à Portaria STN n. 614/06 traz uma série de exemplos, aos quais remetemos o leitor, que ajudam a ilustrar a aplicação dessas regras. Os exemplos não serão aqui repetidos por não consistir no objetivo do presente trabalho.

780 STN. Manual de demonstrativos fiscais, 7. ed., p. 566. 
contratual consolidada ${ }^{781}$, inclusive para fins de aplicação dos limites de endividamento fixados pelo Senado Federal com base na Lei de Responsabilidade Fiscal ${ }^{782}$.

Portanto, para atendimento das regras contábeis estabelecidas pela STN no exercício das atribuições do CGF previsto na LRF, todos os entes federativos, ao contratarem PPP, deveriam estar atentos à necessidade de registrar como dívida parte dos valores a serem pagos no contrato de PPP, a depender das características específicas do contrato. Essa providência seria de enorme importância para entes que estivessem próximos dos limites de endividamento fixados pelo Senado Federal, apresentando-se, contudo, como medida salutar para assegurar a sustentabilidade fiscal das contratações de PPP no longo prazo, especialmente em entes que já se apresentassem altamente endividados.

Contudo, a partir da $8^{\mathrm{a}}$ edição do MDF, válida a partir do exercício orçamentário de 2018, não mais são apresentadas as dívidas contratuais de PPPs como parte integrante da dívida consolidada, mas em apartado, considerando-se que a sua existência, nos dizeres da STN, já onera o limite próprio existente na Lei n. 11.079/2004 ${ }^{783}$. Nas justificativas para a existência de dois limites e retirada das PPPs do cômputo da dívida consolidada, porém, a STN esqueceu-se aparentemente de que o limite previsto no artigo 28 não é limite que se aplica aos estados e municípios, em razão da autonomia federativa de que gozam por força

781 Note-se, como exemplo, o texto da 5a edição, STN. Manual de demonstrativos fiscais, $5^{a}$ ed., p. 561: "Dívida Contratual. Nessa linha, registrar os saldos, do exercício anterior e do exercício de referência até o quadrimestre correspondente, dos débitos de responsabilidade do Governo do respectivo ente, das dívidas realizadas a partir de empréstimos e financiamentos internos e externos, dos refinanciamentos de Estados e Municípios junto ao Governo Federal, além das obrigações financeiras e das operações de crédito assumidas em virtude de contratos de Parceria Público-Privada-PPP registradas no passivo patrimonial. A Dívida Contratual corresponde ao montante total, apurado sem duplicidades, das obrigações financeiras do Ente da Federação, assumidas em virtude de leis, contratos, convênios ou tratados e da realização de operações de crédito, para amortização em prazo superior a doze meses. Também compõem a Dívida Contratual as operações de crédito, que, embora de prazo inferior a 12 (doze) meses, tenham constado com receitas no orçamento."

782 STN. Op. cit., p. 565. Em que pesem os argumentos contrários apresentados pela doutrina, por exemplo, em OLIVEIRA, Fernão Justen. Op. cit., p. 468: "A redação adotada pela lei para o primeiro critério não expressa diretamente se há referência a obrigação de caráter continuado ou a dívida pública consolidada. A distinção é relevante porque o art. 167, II, da CF, estabelece proibição de operações financeiras estatais excedentes ao montante de 'despesas de capital', com exceções que não alcançam as contraprestações com contratos de PPP. A própria conformação da PPP que caracteriza seu objeto como complexo fornece a identificação da despesa total continuada como algo diverso de uma mera obra para pagamento parcelado. A PPP se qualifica justamente pela prestação de um serviço remunerado de acordo com o desempenho do prestador, o que pode ser coligado com a construção da obra que compóe, com esse serviço, a utilidade fruível pelos usuários. Outro óbice à caracterização da despesa total continuada como dívida pública consolidada consiste na inexistência, tecnicamente, de obrigação financeira, nos termos do art. 29, I, da Lei de Responsabilidade Fiscal, mas sim como obrigação futura, conforme o art. 98 da Lei 4.320/1964. Trata-se de despesa não contabilizada como dívida, porque não concorre para a formação ou para a aquisição de um bem de capital."

783 STN. Manual de demonstrativos fiscais, $8^{\text {a }}$ ed., p. 598: "Contratual: Registra o valor total das operações de crédito contratuais, internas e externas realizadas que integram. Destaca-se que o total de contratações de PPP não devem ser computados para fins de limite de Operação de Crédito, uma vez que o limite de contratação de PPP obedece ao disposto nos artigos 22 e 28 da Lei n. 11.079/2004." 
constitucional, mas simplesmente um limite à continuidade de transferências ou à concessão de garantias da União para entes que superem o percentual mencionado neste artigo.

Pode-se concluir, desta maneira, que as parcerias público-privadas são forma alternativa de mobilizar recursos para financiamento de projetos de infraestrutura, no Brasil, com vantagens evidentes sobre as alternativas de financiamento público e investimento direto. Tais vantagens relacionam-se, de forma central, com a eficiência econômica que pode decorrer da adoção de práticas mais modernas de gestão pelo setor privado, em relação ao setor público, e com uma melhor alocação dos riscos.

A chamada "barganha faustiniana", porém, em muitos casos, vem condicionando as escolhas dos gestores públicos que, com o objetivo de afastar do orçamento público os resultados imediatos dos gastos com grandes projetos de investimento, recorrem às parcerias público-privadas. Esse comportamento oportunista, por sua vez, coloca em risco a sustentabilidade fiscal dos governos, considerando os cronogramas financeiros de longo prazo dos contratos de PPP.

Como resposta a essa ameaça, torna-se essencial a análise detalhada, caso a caso, de cada contrato de parceria, de maneira a identificar a essência econômica da operação, o que deve ser feito tendo como referência principalmente a alocação equilibrada dos riscos entre parceiro privado e parceiro público.

Nos casos em que a divisão de riscos leve à conclusão de que o contrato representa, na sua essência, uma operação de financiamento para a aquisição de um bem ou de serviços, a experiência internacional recomenda o reconhecimento de tais contratos como elementos patrimoniais na contabilidade do ente público, fazendo-se a inclusão do ativo construído pela SPE, como bem integrante do patrimônio do parceiro público.

No caso brasileiro, regra semelhante é adotada pela Secretaria do Tesouro Nacional, de forma vinculante para todos os outros entes federados. Nos casos em que o parceiro público assuma parte relevante dos riscos de construção, demanda ou disponibilidade, os ativos gerados pela PPP devem ser inseridos no patrimônio da entidade pública contratante, em contrapartida de formação de dívida de igual valor.

Finalmente, cumpre chamar atenção ao fato de que a dívida gerada dessa forma, a partir do exercício de 2018, deixará de integrar contabilmente a dívida consolidada para todos os efeitos legais, em especial para fins de aplicação dos limites de endividamento contidos nas Resoluções n. 40/01 e 43/01 do Senado Federal, em virtude do previsto na $8^{a}$ edição do Manual de Demonstrativos Fiscais da STN, em clara evidência de inversão da hierarquia do ordenamento jurídico operada na prática das finanças públicas do Brasil, por meio da qual um órgão técnico do governo federal "introduz" ou "retira" itens do conceito de dívida consolidada, sem qualquer legitimidade democrática decorrente de processo legislativo.

\subsubsection{Concessão de garantias}

O problema da concessão de garantias pelo setor público é um problema multifacetado. Por um lado, a concessão de garantias permite ao poder público alavancar recursos para projetos públicos e privados, mobilizando capitais para a sua estratégia de desenvol- 
vimento. Por outro lado, a superexposição do patrimônio público com garantias, de forma pouco transparente, pode representar contingência fiscal grave, podendo comprometer a sustentabilidade fiscal do Estado no longo prazo. São diversas as operações estruturadas que podem ser configuradas valendo-se da estruturação de garantias pelo Poder Público, motivo pelo qual se impõe o estudo desta temática no presente trabalho.

A estruturação de garantias pelo Estado, passa pela compreensão que já discutimos de que o Estado não pode sofrer execução judicial como forma de cobrança de suas dívidas, sujeitando-se ao regime de precatórios, previsto no artigo 100 da CF/88. Em atenção à impossibilidade de execução forçada do Estado, entende-se que a vinculação de receitas públicas como garantia de contratos, especialmente contratos de dívida, ocorre por simples vinculação orçamentária de tais receitas, não sendo possível a sua retenção para autossatisfação ${ }^{784}$.

André Castro Carvalho chama a atenção para o fato de que a vinculação de receitas é, historicamente, o mecanismo de garantia utilizado por Estados que gozam de pouca confiança dos emprestadores. Atualmente, tal mecanismo como forma de garantia de empréstimos viria sendo deixado de lado por países que gozam de maior crédito internacionalmente ${ }^{785}$. Em parte, isto se deveria ao reconhecimento de que a vinculação de receitas limita o exercício da soberania por parte do Estado, impedindo ou pelos menos constrangendo a realização de reformas fiscais que possam reduzir a garantia ${ }^{786}$. Além disso, a constituição de garantias desse tipo, feriria a regra da isonomia constante da Constituição, tratando desigualmente credores do Estado, quando, em verdade, o Estado deveria pagar todas as suas dívidas, sem privilégios e preferências ${ }^{787}$. É claro, porém, que há casos em que a discriminação se justifica, mormente, quando expressamente contemplada no texto constitucional, como é o caso, por exemplo, da preferência de pagamento a créditos de pequeno valor e de créditos alimentares (art. 100).

Muito se discute sobre a questão de a garantia prestada na forma de vinculação de receitas superar o valor do crédito garantido e da possibilidade, neste caso, de desvinculação do excedente. Nesta hipótese, caso fosse constituído fundo de reserva que permitisse fazer frente às amortizações e aos serviços da dívida, restaria atingido o objetivo original da desvinculação de receitas, podendo-se o excedente ser utilizado a partir desse momento sem restriçôes ${ }^{788}$.

784 CARVALHO, André Castro. Vinculação de receitas públicas, p. 132: "Com isto, conclui-se que a vinculação de receitas, na função de garantia (vinculação-garantia), traduz-se no comprometimento orçamentário de que os recursos deverão ser utilizados para o adimplemento da obrigação contraída, sendo vedadas a dupla vinculação e autossatisfação do débito por meio das receitas garantidas.”

785 CARVALHO, André Castro. Op. cit., pp. 132-4.

786 CARVALHO, André Castro. Op. cit., p. 135: "No âmbito internacional, não há como negar a existência de agravamento da soberania de uma nação, além de prejudicar qualquer tentativa de reforma fiscal."

787 CARVALHO, André Castro. Op. cit., p. 139: "Logo, a premissa do uso das vinculações de receitas como justificativa a uma concessão de maior força e confiabilidade ao crédito público, fomentando a solvência estatal, é equivocada em face do pressuposto de que o Estado deve honrar com seus débitos indistintamente e em face de qualquer credor."

788 CARVALHO, André Castro. Op. cit., pp. 135-6: "Neste caso, entendemos que caso haja a vinculação de receitas ao pagamento da dívida, esta afetação não poderia ultrapassar o valor do crédito mais a remunera- 


\section{•• Teoria jurídica do crédito público e operações estruturadas}

Nos projetos de PPPs entende-se que a concessão de garantias serviria à redução do risco (sobretudo o risco político) do parceiro privado nos contratos de longo prazo, favorecendo a concorrência e, por conseguinte, a obtenção de melhores negócios para o poder público. Nesta linha, a constituição de fundos públicos garantidores seria mais eficaz que a simples vinculação de receitas, em razão da possibilidade de contingenciamento destas por limitação de empenho, de movimentação financeira, ou por simples atraso na operacionalização de pagamentos ${ }^{789}$.

A dificuldade na constituição de garantias públicas tem sido apontada como um dos obstáculos à implantação de projetos de infraestrutura pública por meio de parcerias público-privadas no país. O desafio da constituição de garantias pelo Poder Público em projetos de PPPs, mesmo em face do artigo $8^{\circ}$ da Lei n. 11.079/2004, consiste na necessidade "comercial" de que as garantias possam ser executadas sem necessidade de recurso ao Poder Judiciário, o que tornaria inevitável o regime de precatórios ${ }^{790}$.

Com relação a este ponto, é interessante observar que há polêmica sobre a constitucionalidade formal do artigo $8^{\circ}$ da Lei de PPPs, considerando o previsto no artigo 163 , III, da Constituição, que estabelece à lei complementar a competência para a fixação de normas relativas à concessão de garantias pelas entidades públicas. Parte da doutrina entende, porém, que essa competência teria sido exercida por meio do artigo 40 da LRF que, ao não vedar a concessão de garantias em contratos alheios a contratos de operações de crédito, teria permitido ao legislador ordinário a fixação de formas de garantia em outras espécies contratos, como no caso da Lei n. 11.079/2004.

Tendemos a concordar com essa posição, por pensarmos que a chamada "legalidade estrita", sendo o verso do chamado "princípio da legalidade" (art. 5º II, da CF/88), apenas exige expressa autorização em lei para que o Poder Público atue em prejuízo ou restrição das liberdades individuais. Nos demais casos, entendemos que o Poder Público estaria autoriza-

ção pelo capital estabelecida no contrato. Assim, na hipótese de arrecadação suficiente, deverá haver a quitação antecipada da dívida pelo saldo devedor (ou o provisionamento dos recursos, caso não seja possível esta antecipação) e o excedente ser colocado em disponibilidade orçamentária para utilização nas despesas gerais - salvo se houver disposição expressa em contrário. Isto porque se a garantia serve-se ao pagamento da dívida, não há razão para que este excedente fique entesourado, uma vez que o valor da arrecadação descontado o excedente já garantiu - ou garantirá - o pleno adimplemento contratual."

789 CARVALHO, André Castro. Op. cit., pp. 145-6: "Diante disto, ressaltam que o regime de precatórios desestimularia ou até mesmo inviabilizaria a contratação pelos parceiros privados em determinados projetos. As garantias surgiriam como uma diminuição do risco político ao contratante, o que redundaria em melhores propostas à Administração Pública. Para os juristas, no entanto, a única garantia que poderia ter certa margem de segurança ao parceiro privado seria os fundos garantidores, dado que a vinculação de receitas poderia ser sujeita a decretos de contingenciamento, às limitaçôes financeiras e atrasos nos pagamentos, diferentemente desses fundos."

790 OLIVEIRA, Fernão Justen. Garantias ao parceiro privado e comprometimento fiscal, p. 461: "Mas, de regra, o penhor, a fiança, a alienação fiduciária, a hipoteca, não permitem o adimplemento imediato do parceiro privado, devendo o credor promover a execução da garantia em juízo (exceto em casos específicos, como a venda pública ou privada no penhor). Nesse caso de acesso ao Judiciário para tornar eficaz a garantia, perceba-se que a utilidade prática da garantia estará desfeita se o agente garantidor for pessoa jurídica sujeita ao regime de precatório, tanto quanto o parceiro público.” 
do a agir, mesmo que sem autorização expressa, simplesmente em razão da missão constitucionalmente fixada. Como consequência disso, entendemos que o artigo $8^{\circ}$ da Lei $n$. 11.079/2004 é, inclusive, desnecessário no sistema jurídico brasileiro, considerando-se que, mesmo antes da sua aprovação, já seria possível a adoção das garantias nele previstas.

Parte dos autores sustenta, ainda, que o artigo 163, III, se referiria apenas às garantias fidejussórias prestadas em operações de crédito, não havendo reserva de lei complementar às demais formas de garantia ${ }^{791}$. Não podemos concordar com essa doutrina, data venia, em razão do fato de o dispositivo em questão não fazer qualquer ressalva quanto ao tipo de garantia que será tratada em lei complementar, sendo certo que mesmo garantias em projetos de PPPs têm potencial de comprometer as finanças públicas. Assim, há total compatibilidade tópica entre a inclusão deste dispositivo em capítulo referente às finanças públicas na Constituição e a interpretação ampliativa aqui defendida.

Com relação à constitucionalidade material do artigo $8^{\circ}$ da Lei de PPPs, não é possível se afirmar que a constituição de qualquer tipo de garantia possa ser inconstitucional por afronta ao artigo 100 da Constituição. Primeiramente, importa observar que este dispositivo se aplica apenas às Fazendas Públicas, não se alargando de forma a abarcar entidades de direito privado, tais como empresas estatais. Em segundo lugar, o artigo 100 menciona expressamente a necessidade de se observar isonomia entre credores do Estado cujo crédito decorra de decisão judicial ${ }^{792}$ não havendo qualquer regra constitucional que imponha dever de o Estado tratar igualmente credores que se encontram em situação diversa (credores por títulos diversos, tais como título judicial, contrato vigente, garantia real, etc. $)^{793}$.

Em prevalecendo entendimento equivocado de que a Constituição exige tal tratamento idêntico a todos os credores do Estado, o próprio cumprimento de contratos em vigor se apresentaria como violação da ordem de pagamentos estabelecida no artigo 100 da Constituição ${ }^{794}$.

791 SCHIRATO, Vitor Rhein. Op. cit: "Ao versar sobre 'a concessão de garantias pelas entidades públicas', refere-se o inciso III do artigo 163 da Constituição Federal às garantias concedidas em operações de crédito, ou seja, em operaçôes que envolvem a contratação de dívida pela Administração Pública, tendo impacto sobre as metas de equilíbrio fiscal. É dizer, as garantias mencionadas no artigo 163 referem-se, a nosso ver, àquelas garantias fidejussórias prestadas pelas entidades públicas em operações de crédito, sobretudo àquelas que importem em garantia soberana da União Federal a operaçōes contratadas por entidades a ela vinculadas ou por Estados e Municípios."

792 SCHIRATO, Vitor Rhein. Op. cit.: "Entender que a outorga de garantias em favor de determinados credores da Administração Pública, com expressa autorização legislativa, viola o artigo 100 da Constituição Federal, conforme entendemos, não é a melhor interpretação do Direito. Isto ocorre, pois credores dotados de garantias especiais sequer demandarão uma sentença judicial transitada em julgado para o exercício de seus direitos, fazendo com que sequer ocorra no mundo fático a hipótese de incidência de tal dispositivo constitucional."

793 SCHIRATO, Vitor Rhein. Op. cit: "A nosso ver, não há inconstitucionalidade na constituição de garantias diretamente por entidades públicas em favor do parceiro privado em contratos de PPP. A igualdade entre os credores do Poder Público prevista no artigo 100 da Constituição Federal refere-se a credores que estejam na mesma situação, isto é, uma mesma categoria de credores detentores de títulos judiciais transitados em julgado em desfavor da Administração Pública."

${ }^{794}$ CARVALHO, André Castro. Op. cit., p. 152: “Outrossim, não há, no indigitado dispositivo, açoite ao regime de precatórios, pois este pressupõe a existência de crédito controvertido em face da Fazenda Pú- 


\section{•• Teoria jurídica do crédito público e operações estruturadas}

A vinculação de receitas não constitui necessariamente uma garantia propriamente dita, mas sim um "reforço de crédito", no sentido de que assegura os recursos necessários ao pagamento dos compromissos contratuais assumidos ${ }^{795}$. Não se autoriza, contudo, pela simples vinculação das receitas orçamentárias, a sua execução forçada para pagamento das obrigaçōes contratuais pecuniárias eventualmente inadimplidas pelo Poder Público ${ }^{796}$. Daí porque se afirma que o grande risco dessa forma de garantia, consiste justamente no fato de não permitir a execução forçada dos recursos públicos, tornando necessário o recurso ao Poder Judiciário e, consequentemente, tornando inevitável que a execução se dê por meio do regime de precatórios previsto no artigo 100 da Constituição Federal ${ }^{797}$.

Não se pode tratar igualmente a situação em que o Estado apresenta à sua contraparte um reforço de crédito para contratação e a situação em que o Estado, inadimplente, sofre condenação transitada em julgado para pagamento de quantia e posteriormente execução de tal condenação na forma do regime de precatórios. Na segunda hipótese, de fato, a constituição de forma diversa de execução das condenações judiciais, por meio de fundo ou de vinculação de receita específica poderia ser considerada inconstitucional, por ser contrária ao artigo 100 da Constituição. Porém, na primeira hipótese, não se trata de

blica: há o direito de crédito pelo particular contra a Administração que não é prontamente reconhecido por ela, de forma que se faz mister a existência de uma sentença judicial transitada em julgado para que haja a obrigação de pagamento ao credor." E continua na p. 153: "E não há nada de inconstitucional nisto. Se assim o fosse, a Administração Pública nunca poderia contratar com particulares, pois o mero adimplemento contratual feriria o regime de precatórios, afinal, esse ato acarretaria a preterição da ordem de pagamento dos créditos."

795 SCHIRATO, Vitor Rhein. Os sistemas de garantia nas parcerias público-privadas. Fórum de Contratação e Gestão Pública - FCGP: "A vinculação de receitas é um mecanismo orçamentário e, conforme a estruturação no negócio, contratual. A sistemática de vinculação de receitas não permite a constituição de um direito real de garantia em favor do particular. Apenas acena com a existência de uma receita específica que servirá para garantir o integral e pontual pagamento das obrigações do parceiro público nos termos do contrato de PPP celebrado.

Haverá uma obrigação (legal e, dependendo do arranjo do projeto, contratual) de o parceiro público utilizar os recursos vinculados para o pagamento dos valores devidos. Todavia, não é assegurado ao particular o direito de tomar os recursos para si e proceder à sua excussão, conforme mecanismo assegurado ao credor contemplado com direito real de garantia."

796 BINENBOJM, Gustavo. As parcerias público-privadas e a vinculação de receitas dos fundos de participação como garantia das obrigações do poder público, p. 477: “(...) A vinculação de receitas constitui uma garantia de ordem orçamentária, pela qual se afeta determinada receita a uma finalidade específica. Não é, pois, uma segurança especial a que o credor terá direito em caso de inadimplemento da dívida, um contrato acessório cujo objetivo é permitir a execução da obrigação principal, em caso de inadimplemento, sem a necessidade de se ajuizar uma ação de conhecimento. Antes, trata-se de um indicador de que o contrato principal será cumprido espontaneamente, e de que as obrigaçōes pecuniárias contraídas pelo Poder Concedente serão adimplidas sem contratempos."

797 SCHIRATO, Vitor Rhein. Op. cit.: "Entretanto, essa sistemática apresenta alguns riscos para o parceiro privado, pois não é mais concreta, sólida e líquida das formas de garantia em operações dessa natureza. Os riscos decorrentes da inexistência de direito real de garantia são, ainda, agravados pela impossibilidade de ação de execução patrimonial direta com vistas à penhora dos recursos vinculados contra a Administração Pública, com fundamento no artigo 100 da Constituição Federal, o que dificulta ainda mais o acesso do parceiro privado aos recursos vinculados." 
execução de condenação judicial, mas de adimplemento de obrigação contratual. Assim, a existência de mecanismos contratuais ou legais de reforço ao crédito do setor público não são inconstitucionais, assim como não seria inconstitucional a previsão de dotação orçamentária em valor conscientemente superior ao da despesa esperada, apenas como forma de reservar recursos suficientes para o adimplemento de eventual contrato mesmo diante de situação financeira mais desafiadora ${ }^{798}$. O artigo 100 da CF/88 não pode ser lido como impedimento absoluto à constituição de garantias pelo Poder Público ${ }^{799}$.

Também não pode o artigo $100 \mathrm{da} \mathrm{CF} / 88$, em nossa opinião, ser utilizado de maneira a obstar a constituição de garantias reais sobre bens imóveis por parte do ente público, desde que a garantia ocorra em modalidade que prescinda de sentença judiciária para a sua execução. Não se deve, neste contexto, considerar a impenhorabilidade dos bens públicos um óbice intransponível.

Embora os bens públicos, em regra, sejam impenhoráveis e inalienáveis, o que impediria o seu gravame por meio de penhor ou hipoteca, essa regra pode ser afastada pela expressa desafetação do bem público, autorizando-se em lei a sua destinação como forma de garantia ${ }^{800}$. Isto, pois, se se conclui que, desafetados, os bens públicos podem ser alie-

798 CARVALHO, André Castro. Op. cit., pp. 152-3: “Outrossim, não há, no indigitado dispositivo, açoite ao regime de precatórios, pois este pressupõe a existência de crédito controvertido em face da Fazenda Pública: há o direito de crédito pelo particular contra a Administração que não é prontamente reconhecido por ela, de forma que se faz mister a existência de uma sentença judicial transitada em julgado para que haja a obrigação de pagamento ao credor.

Já no caso de execução dos contratos, não há o inadimplemento contratual. Pelo contrário: há o interesse da Administração em cumprir com as suas obrigaçôes contratuais, primeiro mediante o uso das receitas afetadas e, caso seja insuficiente, via outras dotaçôes orçamentárias. Por evidente que, em respeito ao pacta sunt servanda, na hipótese de os referidos recursos serem insatisfatórios, a Administração Pública deverá valer-se de outros meios orçamentários para satisfazer o crédito de seu credor, sem que isto implique violação ao regime de precatórios incrustado no artigo 100 da Constituição Federal.

E não há nada de inconstitucional nisto. Se assim o fosse, a Administração Pública nunca poderia contratar com particulares, pois o mero adimplemento contratual feriria o regime dos precatórios, afinal, esse ato acarretaria a preterição da ordem de pagamento dos créditos. Se não houvesse a diferenciação entre os créditos oriundos de sentença judicial e os de contratos administrativos ainda não executados, não haveria o porquê de existir o regime de precatórios, de forma que todo crédito em face da Administração deveria seguir a ordem de cumprimento determinada. Isto seria irracional do ponto de vista contratual, uma vez que fatalmente não haveria um indivíduo que se sujeitasse a tal hipótese, já que não existirá uma certeza de pronto pagamento pelo poder público, mas sim uma mera probabilidade, devendo o credor aguardar o seu crédito, controvertido ou não, em uma 'fila' até o seu recebimento."

799 BINENBOJM, Gustavo. Op. cit., p. 480: "O art. 100 da CF, portanto, não pode ser lido de forma absoluta, como se toda e qualquer afetação de recursos fosse ilegítima, ou como se todo e qualquer pagamento realizado pelo Poder Público representasse, a priori, violação à ordem cronológica dos precatórios. O regime de precatórios somente se aplica ao pagamento de condenaçôes referentes a exercícios pretéritos."

${ }^{800}$ BINENBOJM, Gustavo. Op. cit., p. 480, n. 12: “(...) seria legítimo ao Poder Público desafetar determinado bem imóvel de seu patrimônio e dá-lo em garantia de um contrato. A desafetação do bem importa a possibilidade de disposição do bem, o que se pode fazer mediante as formas contratuais admitidas pelo direito. A constituição de uma hipoteca, por exemplo, seria uma forma válida de garantir um contrato de que o Poder Público fosse parte." Exceção deve ser feita às terras tradicionalmente ocupadas por índios, em função do que prevê o artigo 231, $\$ 4^{\circ}$, da Constituição Federal de 1988: "Art. 231. São reco- 


\section{•• Teoria jurídica do crédito público e operações estruturadas}

nados, então, é necessário aceitar que também poderão servir de garantia ${ }^{801}$. Nesta ordem, atende o procedimento público ${ }^{802}$ ou particular de alienação dos bens, em caso de inadimplemento, a exigência de licitação para a alienação de bens públicos, sempre que se assegure nesse procedimento a possibilidade de ampla participação de interessados na aquisição do bem ${ }^{803}$.

Pelos mesmos motivos, não há óbice à utilização da alienação fiduciária em garantia, desde que desafetados os bens e autorizada legislativamente (no caso de bens imóveis) a transferência resolúvel da propriedade do bem, como forma de garantir contrato de que faça parte o Poder Público. Contudo, considerando-se que a principal vantagem da alienação fiduciária em relação ao penhor é a exclusão dos bens dados em garantia da massa falida, em caso de concurso de credores, e dada a condição peculiar de não sujeição à falência do Poder Público, do ponto de vista prático, obtém-se por meio da alienação fiduciária garantia muito semelhante à obtida na forma do penhor ou da hipoteca ${ }^{804}$.

nhecidos aos índios sua organização social, costumes, línguas, crenças e tradições, e os direitos originários sobre as terras que tradicionalmente ocupam, competindo à União demarcá-las, proteger e fazer respeitar todos os seus bens. (...) $\$ 4^{\circ}$ As terras de que trata este artigo são inalienáveis e indisponíveis, e os direitos sobre elas, imprescritíveis."

801 SCHIRATO, Vitor Rhein. Op. cit.: "Nesta toada, poderá haver a constituição de penhor sobre um determinado bem público, caso tenha sido desconstituída sua afetação para um fim público e tenha sido sua gravação autorizada por lei. É evidente que a simples constituição de penhor não implica em alienação do bem como já observamos acima, a constituição de penhor não importa em transferência de propriedade. Contudo, é praticamente ineficaz o penhor cuja excussão fique condicionada a uma aprovação legislativa. Ainda que fosse mecanismo juridicamente possível, não seria comercialmente aceitável.” E em seguida, tratando especificamente sobre a hipoteca: "Em linhas gerais, os comentários apresentados acima com relação ao penhor também são aplicáveis à hipoteca, inclusive naquilo que concerne ao tema da necessidade de autorização legislativa para a gravação e possível alienação do bem. A maior distinção refere-se ao processo de alienação, visto que os bens imóveis hipotecados somente podem ser alienados por meio de venda pública, o que satisfaria o requisito de licitação. Segundo entendemos, o bem imóvel público poderá ser hipotecado e alienado, caso seja desafetado (melhor dizendo: tenha sido afetado para a finalidade de constituição de garantia) por meio da autorização legislativa competente."

802 SCHIRATO, Vitor Rhein. Op. cit.: "No caso da venda judicial em hasta pública, parece-nos não haver qualquer contrariedade ao artigo 17 da Lei n. 8.666/93, visto que o processo de alienação do bem empenhado por meio de venda pública é uma forma de processo licitatório. Não obstante não ser exatamente o processo formal previsto na Lei n. 8.666/93, é processo público que assegura igualdade de chances a todos os interessados e procura assegurar o recebimento da melhor proposta financeira, em estrita consonância com a finalidade da licitação."

803 SCHIRATO, Vitor Rhein. Op. cit.: "Destarte, segundo entendemos, a excussão do penhor sobre um dado bem público poderá ser realizada sem maiores questionamentos por meio de venda judicial em hasta pública, bem como por meio de venda amigável, desde que neste último caso seja realizada a alienação em processo que assegure a todos os potenciais interessados o direito de participar da disputa e arrematar o bem excutido, em consonância com as determinaçôes do artigo 17 da Lei n. 8.666/93.”

804 SCHIRATO, Vitor Rhein. Op. cit.: "Do ponto de vista do credor (beneficiário da garantia), a grande distinção entre se adotar penhor ou alienação fiduciária como forma de garantia de obrigações pecuniárias refere-se à hipótese de falência do devedor. Isto ocorre, pois, no caso de alienação fiduciária, o bem alienado não fará parte da massa falida e, portanto, não será arrecadado para liquidação do ativo, ao contrário do que ocorre com relação ao penhor, em que o bem empenhado integrará a massa falida por não ter sua propriedade sido transferida ao credor. 
Vitor Rhein Schirato faz interessante distinção entre bens públicos e receitas públicas, sobre as quais defende que não se aplicam os privilégios dos bens públicos (inalienabilidade, imprescritibilidade, impenhorabilidade) ao menos até a sua efetiva arrecadação $^{805}$.

Não se pode, porém, concordar totalmente com essa visão, sem efetuar um reparo, pois entendemos que, ou o direito de crédito é efetivo (no caso, por exemplo, em que já existe uma relação jurídica obrigacional - tributária ou não) e, então, se aplica o regime de bens públicos, pois o artigo 83 do CC/02 expressamente inclui os direitos pessoais de caráter patrimonial e respectivas ações no conceito de bens móveis para fins legais; ou, o direito de crédito é eventual e se trata apenas de expectativa, sobre a qual não pode pesar as mesmas restriçôes jurídicas aplicáveis aos bens públicos, mas cujo valor econômico é igualmente infimamente menor. Para que se possa concordar com a distinção apresentada pelo autor, é preciso que se trate especificamente do segundo caso.

É preciso observar que todas as receitas públicas, exceto os impostos, por força do artigo 167, IV, da Constituição podem ser vinculadas por lei. A vinculação por lei, mais do que uma exigência jurídica, é uma exigência prática, de maneira a realmente conferir eficácia à vinculação, isto, pois qualquer vinculação que ocorra por ato infralegal poderá ser modificada por ato de vontade do próprio governante, não representando, por consequência, verdadeira vinculação ${ }^{806}$.

No caso específico das garantias constituídas para aumento da segurança dos contratos de PPP, essa vantagem acaba por não fazer muito sentido, uma vez que os órgãos, entes e entidades que poderão figurar como poder concedente em contratos de PPP e, via de consequência, que serão os constituintes de garantia não estão sujeitos à falência, fazendo com que, em termos práticos, não haja distinções relevantes entre penhor e alienação fiduciária como forma de garantia dos contratos de PPP.”

805 SCHIRATO, Vitor Rhein. Op. cit.: “(...) Desde há muito existe no Brasil o entendimento de que receitas públicas não seriam passíveis de qualquer gravame, em razão das características especiais de que gozam os bens públicos (inter alia, inalienabilidade, imprescritibilidade e impenhorabilidade).

Preliminarmente, acerca deste tema, um esclarecimento faz-se necessário: as receitas públicas são direitos de crédito constituídos por lei ou outro mecanismo juridicamente apto em favor do Poder Público. As receitas, de per se, não são bens públicos, mas sim direitos de crédito do Poder Público. Os recursos advindos da realização de tal direito de crédito, se e quanto realizados, serão bens públicos. Há, portanto, uma distinção fundamental: ao se falar em receitas, fala-se em direitos (de natureza jurídica obrigacional) e não em bens (de natureza jurídica real). Destarte, não há como se falar que sobre o conceito de receita possa recair o regime jurídico dos bens públicos.

Nada obstante, os recursos provenientes das receitas, quando de sua realização, tornar-se-ão bens públicos e, portanto, terão sobre si incidente o regime de bens públicos."

806 CARVALHO, André Castro. Op. cit., p. 148: "Diante disto, o artigo 8º, I, mais do que meramente declaratório, é prescindível no ordenamento, vasto que toda vinculação de receitas que não a de impostos ocorrerá por força de lei - em obediência ao caráter jurídico das vinculações, o que poderia ser feito sem a existência do referido comando na Lei das PPPs. Isto porque, conforme ventilado, qualquer vinculação por ato normativo que não seja legal ou constitucional é perfeitamente mutável por ato de mesmo grau do Poder Executivo, o que, na prática, não constituirá vinculação alguma.

Isto porque ela poderá ser extinta a qualquer momento, não configurando, destarte, a concessão da segurança financeira que é o mote do estabelecimento de uma vinculação-garantia. Outra opção, ainda, seria a constituição de garantia por dotação orçamentária ad hoc, a ser definida em edital ou no contrato de concessão, mas tal técnica também não constituirá a vinculação de receitas como garantia." 


\section{•• Teoria jurídica do crédito público e operações estruturadas}

Com relação à proibição de vinculação de receitas de impostos, é preciso ressaltar que essa vedação não se aplica, em nossa opinião, à receita para estados e município oriunda de transferência de impostos de competência de outros entes da federação ${ }^{807}$, visto que essa receita, para o ente recebedor, não consiste em receita oriunda de impostos, mas sim em receita de transferências, conforme determina o artigo $11, \$ 1^{\circ}$, in fine, da Lei $n$. $4.320 / 1964^{808}$. Reconhecemos, porém, a existência de precedente do STF que parece caminhar em sentido contrário ${ }^{809}$, pelo menos no que se refere à vinculação de receitas para a constituição de fundos públicos.

Ainda no tema das garantias por meio da vinculação de receitas, vale observar a decisão cautelar proferida pelo STF nos autos da Arguição de Descumprimento de Preceito Fundamental (ADPF) n. $405 \mathrm{MC} / \mathrm{RJ}$, por meio da qual suspendeu-se, até o julgamento de mérito, os efeitos de

807 BINENBOJM, Gustavo. Op. cit., p. 488: "Percebe-se, assim, que o esquema de vinculação dos recursos financeiros repassados pela União aos Estados e aos Municípios, por via do FPE e do FPM, em contratos de PPP, não contraria o art. 167, IV, da CF, que enuncia o princípio da não vinculação, sendo perfeitamente possível, do ponto de vista jurídico, a sua previsão por legisladores locais, estaduais ou municipais."

${ }^{808}$ DIETERICH BOPP, Frederico. Mitigação de risco para projetos de parcerias público-privadas no Brasil: a estruturação de garantias públicas, p. 31: "Em contraposição a esse argumento [do artigo 167, IV da $\mathrm{CF} / 88$ ] é possível alegar que, com o repasse do montante da União aos municípios e Estados, o recurso perde a natureza de imposto, assumindo a natureza de transferência constitucional, não se sujeitando, portanto, à vedação constitucional."

809 ADI 553/RJ, rel. Min. Cármen Lúcia, julgamento em 13.6.2018. (ADI-553): "Com esse entendimento, o Plenário julgou procedente pedido formulado em ação direta para declarar a inconstitucionalidade do art. 226, $\$ 1^{\circ}$ (2) (renumeração do art. 223), da Constituição do Estado do Rio de Janeiro, que cria o Fundo de Desenvolvimento Econômico e a ele destina recursos provenientes do Fundo de Participação dos Estados.

O Colegiado julgou, ainda, prejudicada a ação quanto ao art. 56 (3) do Ato das Disposições Constitucionais Transitórias da Constituição estadual por se tratar de norma cuja eficácia se exauriu há dezoito anos.

(1) CF: 'Art. 167. São vedados: (...) IV - a vinculação de receita de impostos a órgão, fundo ou despesa, ressalvadas a repartição do produto da arrecadação dos impostos a que se referem os arts. 158 e 159, a destinação de recursos para as ações e serviços públicos de saúde, para manutenção e desenvolvimento do ensino e para realização de atividades da administração tributária, como determinado, respectivamente, pelos arts. 198, $\$ 2^{\circ}, 212$ e 37, XXII, e a prestação de garantias às operações de crédito por antecipação de receita, previstas no art. $165, \$ 8^{\circ}$, bem como o disposto no $\$ 4^{\circ}$ deste artigo'.

(2) Constituição do Estado do Rio de Janeiro: 'Art. 226 - Fica criado o Fundo de Desenvolvimento Econômico, voltado para o apoio e estímulo de projetos de investimentos industriais prioritários do Estado. $\$ 1^{\mathrm{o}}$ - Ao Fundo de Desenvolvimento Econômico serão destinados recursos de, no mínimo, $10 \%$ (dez por cento) do total anualmente transferido para o Estado, proveniente do Fundo de Participação dos Estados, previsto no artigo 159, inciso I, letra 'a', da Constituição da República, dos quais $20 \%$ (vinte por cento) se destinarão a projetos de microempresas e de empresas de pequeno porte.'

(3) Ato das Disposiçōes Constitucionais Transitórias do Estado do Rio de Janeiro: 'Art. 56 - Durante dez anos o Estado aplicará, no mínimo, $10 \%$ (dez por cento) dos recursos do Fundo para o Desenvolvimento de que trata o artigo 226 nos projetos de infraestrutura para industrialização, assegurando o desenvolvimento econômico das regiōes norte e noroeste fluminenses, de acordo com os planos municipais e regionais de desenvolvimento, ficando assegurada aos Municípios do noroeste fluminense a metade dos recursos destinados às regiōes."” 
Operações estruturadas: conceito, oportunidades e impactos nas finanças públicas

todas as decisões judiciais do Tribunal de Justiça do Estado do Rio de Janeiro (TJRJ) e do Tribunal Regional do Trabalho da $1^{\text {a }}$ Região (TRT1) que tenham determinado o arresto, o sequestro, o bloqueio, a penhora ou a liberação de valores das contas administradas pelo Estado do Rio de Janeiro, para atender a demandas relativas a pagamento de salários, a satisfação imediata de créditos de prestadores de serviços e tutelas provisórias definidoras de prioridades na aplicação de recursos públicos, exclusivamente nos casos em que estas determinações tenham recaído sobre recursos escriturados, com vinculação orçamentária específica ou vinculados a convênios e operações de crédito, valores de terceiros sob a administração do Poder Executivo e valores constitucionalmente destinados a municípios ${ }^{810}$.

Conforme se verifica, ao menos em sede cautelar, a vinculação parece que terá sua eficácia assegurada pelo STF, na medida em que este Tribunal não permitirá que haja a execução de outras dívidas com a expropriação de recursos vinculados orçamentariamente, convênio ou contrato, o que preserva as vinculações existentes.

Vale ainda a pena tratar da previsão contida no artigo 40, II, quanto à garantia de dívidas entre unidades da Federação. Para José Maurício Conti, a possibilidade de condicionar a entrega de recursos do Fundo de Participaçóes dos Estados ou dos Municípios à inexistência de dívidas em aberto com Estados e com a União não implica a possibilidade de autossatisfação destes entes por meio dos recursos represados, o que representaria violação ao federalismo fiscal ${ }^{811}$. Assim, conclui o autor pela inconstitucionalidade do artigo

810 ADPF 405 MC/RJ, Rel. Min. Rosa Weber, julgamento em 14 de junho de 2017. Ver Informativo de Jurisprudência STF n. 869: “(...) Consignou que os documentos trazidos aos autos apontam que as sucessivas expropriações de numerário existente nas contas do Estado do Rio de Janeiro, para saldar os valores fixados nas decisões judiciais, têm alcançado recursos de terceiros, escriturados contabilmente, individualizados ou com vinculação orçamentária específica. Essas determinaçôes judiciais de bloqueio, penhora, arresto, sequestro e liberação de verbas públicas alteram a destinação orçamentária dos recursos públicos, remanejando-os de uma categoria de programação para outra, sem prévia autorização legislativa. Por isso, pelo menos aparentemente, são dificilmente conciliáveis com as vedaçôes contidas no art. 167, VI e X, da Constituição da República.

A aparente usurpação de competências constitucionais reservadas ao Poder Executivo (exercer a direção da Administração) e ao Poder Legislativo (autorizar transposição, remanejamento ou transferência de recursos de uma categoria de programação para outra ou de um órgão para outro) sugere configurada, na hipótese, provável lesão aos arts. 2 (11); 84, II (12); e 167, VI e X, da Carta Política.

O Tribunal, por fim, asseverou ser passível de tutela jurisdicional a realização de políticas públicas, sobretudo para atender mandamentos constitucionais e assegurar direitos fundamentais. No entanto, a subtração de qualquer margem de discricionariedade do chefe do Poder Executivo na execução das despesas sugere haver indevida interferência do Poder Judiciário na administração do orçamento e na definição das prioridades na execução de políticas públicas, em conflito com o disposto nos arts. 2º e 84, II, da Carta Política, o que suscita preocupações também sob o prisma da harmonia entre os Poderes. Além de comprometer a autonomia administrativa do Estado, por retirar do chefe do Poder Executivo os meios essenciais à alocação de recursos financeiros, a proliferação de decisões judiciais que determinam constrições imediatas, em descompasso com o cronograma de desembolso orçamentário, parece colocar alguns credores em situação mais vantajosa do que outros em igual condição fática e jurídica, quebrando a isonomia. Reputou presente, portanto, o "fumus boni iuris" e devidamente preenchido o requisito do "periculum in mora" em face do elevado risco de comprometimento do patrimônio e das receitas correntes do Estado do Rio de Janeiro. (...)"

811 CONTI, José Maurício. Federalismo Fiscal e Fundos de Participação, p. 121: "O ato de condicionar a entrega de recursos não autoriza, em momento algum, a utilização destes recursos. Qualquer interpre- 


\section{•• Teoria jurídica do crédito público e operações estruturadas}

40, II, in fini, da LRF, quando permite o emprego dos recursos retidos para liquidação da dívida em aberto ${ }^{812}$.

Ao mesmo tempo em que concordamos com a colocação de José Maurício Conti, chamamos a atenção para o fato, como já ressaltamos anteriormente, de que a prática dos contratos de dívida e garantias acessórias é ainda mais violadora do pacto federativo do que a hipótese apresentada na LRF e combatida pelo argumento descrito. Isto pois não é incomum que contratos de dívida entre entes federativos, sobretudo os assinados com a União Federal, prevejam a possibilidade de autossatisfação do credor por meio de mandato conferido ao agente financeiro do ente subnacional para que retenha os recursos eventualmente existentes em contas correntes do ente devedor e os aplique na quitação da dívida existente, em caso de inadimplência ${ }^{813}$.

Este tema está atualmente em debate no STF na Ação Civil Originária n. 2972, na qual se discutem bloqueios realizados em contas do Estado do Rio de Janeiro por força de execução de cláusulas de garantia contidas nos contratos de dívida com a União e na qual foi proferida decisão liminar, pela qual ficou

tação neste sentido é extensiva e, por conseguinte, inadmissível neste caso, em face das razões já anteriormente apontadas. Portanto, a permissão do parágrafo único do art. 60 é para que os recursos a serem transferidos sejam mantidos depositados na conta respectiva, em favor das unidades beneficiárias sem que estas possam retirá-los, até que se salde as dívidas que deram origem à autorização para a retenção.” E novamente na p. 123: "Em sendo restritiva a única interpretação, admissível na hipótese, não se, é possível estender, de modo algum, o conteúdo da disposição constitucional. Logo, não se pode atribuir ao verbo vincular significado que não lhe é próprio, qual seja, o significado de entregar, ou dar. Assim, quando a Constituição autoriza Estados, Distrito Federal e Municípios a vincular receitas próprias e transferidas ao pagamento de débitos federais, não está autorizando a União a se apropriar dos referidos recursos quando entender cabível, sem anuência dos devedores, efetivos proprietários destes recursos. A vinculação, neste caso, restringe-se à obrigação das unidades devedoras de estabelecerem, que os recursos fiquem reservados para o pagamento das dívidas assumidas com a União.”

812 CONTI, José Maurício. Op. cit., p. 124.

813 Ver, por exemplo, Cláusula Décima do "Contrato de Confissão, Consolidação, Promessa de Assunção e Refinanciamento de Dívidas” entre o Município de São Paulo e a União Federal, assinado em 3 de maio de 2000, e confirmado por diversos termos aditivos ao longo dos anos seguintes: "CLÁUSULA DÉCIMA. O MUNICÍPIO se obriga, durante toda a vigência deste Contrato, a manter conta de depósitos no AGENTE, suprindo-a com recursos suficientes à cobertura dos compromissos decorrentes deste Contrato em seus vencimentos, e, neste ato, autoriza o AGENTE, em caráter irrevogável e irretratável, independentemente de qualquer aviso ou notificação, a efetuar débitos na conta n. 451.127-1, agência São João, prefixo n. 1893-7, e, caso esses recursos não satisfaçam a totalidade do débito, o MUNICÍPIO autoriza o DEPOSITÁRIO, em caráter irrevogável e irretratável, a transferir ao AGENTE, mediante débito à conta de centralização de receitas próprias do MUNICÍPIO, Agência CENTRAL, n. 001, Cidade de São Paulo, conta corrente n. 0001-45-000391, titular PMSP - Secretaria de Finanças - Arrecadação, quantias suficientes à liquidação das obrigações financeiras ora pactuadas. PARÁGRAFO ÚNICO. O MUNICÍPIO se compromete a manter a conta de centralização de receitas próprias referida no caput e a somente substituir a instituição depositária após comunicação à UNIÃO, por intermédio da Secretaria do Tesouro Nacional, e ciência ao AGENTE, e desde que a nova instituição depositária se manifeste formalmente de acordo com os termos deste Contrato, no que se refere às obrigações do DEPOSITÁRIO.” 
'suspensa a execução das cláusulas de contragarantia dos contratos em questão (docs. 1 e 2), sem observância do direito à notificação e defesa prévias, devidamente sopesadas e apreciadas, bem assim, a suspensão de todos os efeitos que lhe seriam imputados na condição de devedor, inclusive os reflexos em restrições legais que impedem o acesso e a obtenção a novos financiamentos...' até a reapreciação desta decisão pelo Ministro Relator ou a sua submissão por ele dessa decisão ao Colegiado para o seu referendum. ${ }^{814}$

Como vem sendo a tônica do presente trabalho, nota-se também com relação à possibilidade de concessão de garantias pelo Estado em operações estruturadas um espaço tanto para oportunidades como para descontrole e riscos fiscais. A possibilidade de concessão de garantias é central para a eficácia das operaçôes estruturadas enquanto mecanismo de alocação de recursos para o atingimento de objetivos públicos, visando ao desenvolvimento econômico e social do país. Contudo, a concessão de garantias pode representar a origem de contingências fiscais nem sempre adequadamente mapeadas e que podem, se realizadas, comprometer o planejamento financeiro e orçamentário do Estado.

A partir desse diagnóstico, justifica-se a atenção que vem sendo dada ao tema, tanto do ponto de vista do direito administrativo, quando do direito financeiro. Entretanto, é preciso afastar alguns mitos que se implantaram ao longo do tempo e que procuramos apresentar neste item do presente trabalho, em especial o mito da inconstitucionalidade da concessão de garantias públicas em face do artigo 100 da CF/88 e, em face totalmente oposta, o mito da gratuidade da concessão de garantias pelo setor público e da sua neutralidade em relação às estatísticas fiscais.

814 ACO n. 2972, rel. Ministro Ricardo Lewandowsky, DJE n. 18 (01 de fevereiro de 2017). 